Prepared in cooperation with the San Bernardino Valley Municipal Water District

\title{
Geohydrologic and Water-Quality Data in the Vicinity of the Rialto-Colton Fault, San Bernardino, California
}

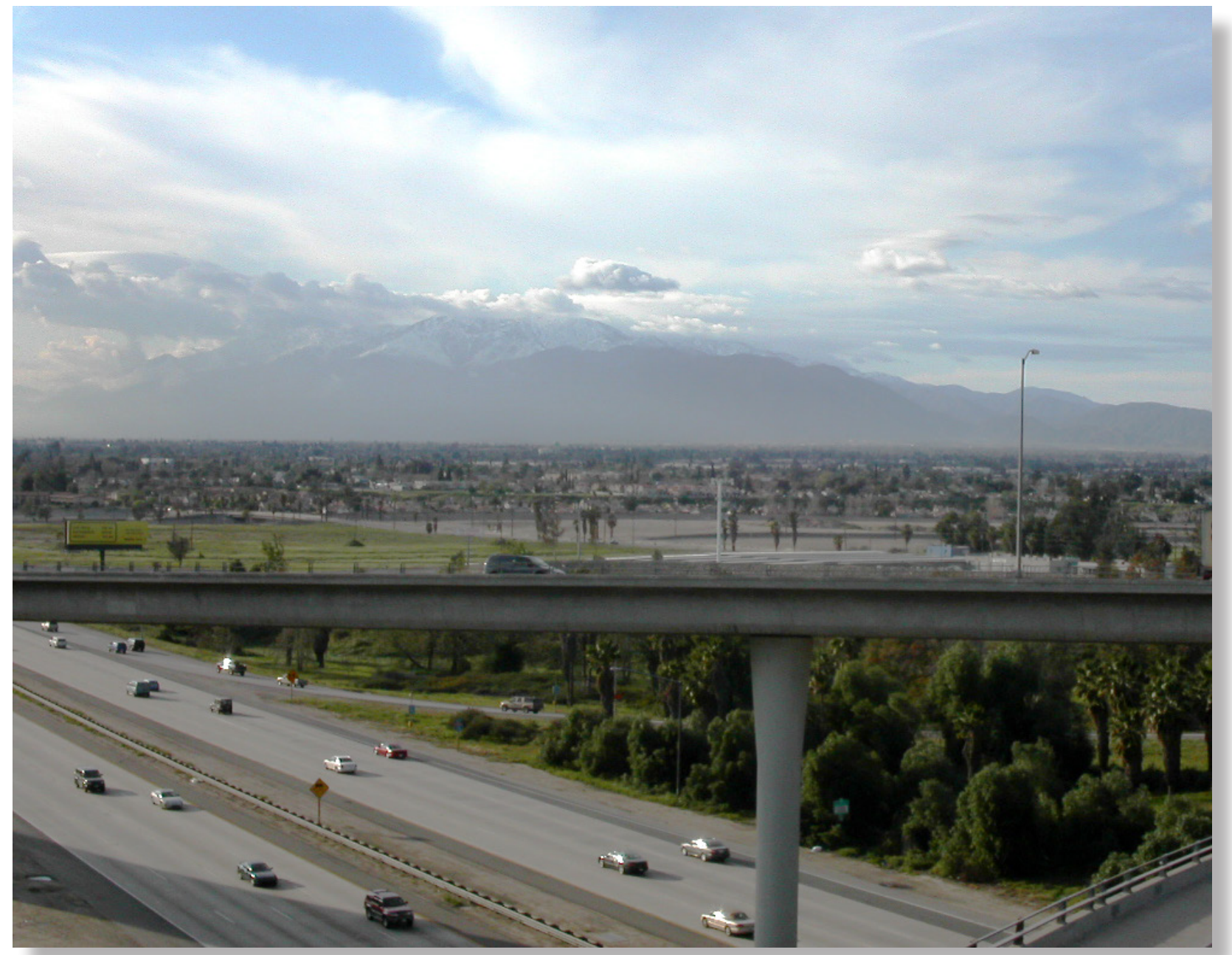

Data Series 813 
Cover. The Rialto-Colton area looking northwest towards the San Gabriel Mountains. (Photograph by Anthony Brown, U.S. Geological Survey) 


\section{Geohydrologic and Water-Quality Data in the Vicinity of the Rialto-Colton Fault, San Bernardino, California}

By Nick Teague, Anthony A. Brown, and Linda R. Woolfenden

Prepared in cooperation with the San Bernardino Valley Municipal Water District West Valley Water District

Data Series 813 


\title{
U.S. Department of the Interior SALLY JEWELL, Secretary
}

\section{U.S. Geological Survey Suzette M. Kimball, Acting Director}

\author{
U.S. Geological Survey, Reston, Virginia: 2014
}

For more information on the USGS - the Federal source for science about the Earth, its natural and living resources, natural hazards, and the environment, visit http://www.usgs.gov or call 1-888-ASK-USGS.

For an overview of USGS information products, including maps, imagery, and publications, visit http://www.usgs.gov/pubprod

To order this and other USGS information products, visit http://store.usgs.gov

Any use of trade, firm, or product names is for descriptive purposes only and does not imply endorsement by the U.S. Government.

Although this information product, for the most part, is in the public domain, it also may contain copyrighted materials as noted in the text. Permission to reproduce copyrighted items must be secured from the copyright owner.

Suggested citation:

Teague, Nick, Brown, A..A., and Woolfenden, L.R., 2014, Geohydrologic and water-quality data in the vicinity of the Rialto-Colton Fault, San Bernardino, California: U.S. Geological Survey Data Series 813, 76 p., http://dx.doi.org/10.3133/ds813. 


\section{Conversion Factors}

Inch/Pound to SI

\begin{tabular}{|c|c|c|}
\hline Multiply & By & To obtain \\
\hline \multicolumn{3}{|c|}{ Length } \\
\hline inch (in.) & 2.54 & centimeter $(\mathrm{cm})$ \\
\hline inch (in.) & 25.4 & millimeter (mm) \\
\hline foot $(\mathrm{ft})$ & 0.3048 & $\operatorname{meter}(\mathrm{m})$ \\
\hline mile (mi) & 1.609 & kilometer $(\mathrm{km})$ \\
\hline \multicolumn{3}{|c|}{ Area } \\
\hline acre & 4,047 & square meter $\left(\mathrm{m}^{2}\right)$ \\
\hline acre & 0.004047 & square kilometer $\left(\mathrm{km}^{2}\right)$ \\
\hline square mile $\left(\mathrm{mi}^{2}\right)$ & 259.0 & hectare (ha) \\
\hline square mile $\left(\mathrm{mi}^{2}\right)$ & 2.590 & square kilometer $\left(\mathrm{km}^{2}\right)$ \\
\hline \multicolumn{3}{|c|}{ Volume } \\
\hline ounce, fluid (fl. oz) & 29.57 & milliliter $(\mathrm{mL})$ \\
\hline ounce, fluid (fl. oz) & 0.02957 & liter $(\mathrm{L})$ \\
\hline
\end{tabular}

Temperature in degrees Celsius $\left({ }^{\circ} \mathrm{C}\right)$ may be converted to degrees Fahrenheit $\left({ }^{\circ} \mathrm{F}\right)$ as follows:

${ }^{\circ} \mathrm{F}=\left(1.8 x^{\circ} \mathrm{C}\right)+32$

Vertical coordinate information is referenced to the North American Vertical Datum of 1988 (NAVD 88).

Altitude, as used in this report, refers to distance above the vertical datum.

Specific conductance is given in microsiemens per centimeter at 25 degrees Celsius $(\mu \mathrm{S} / \mathrm{cm}$ at $\left.25^{\circ} \mathrm{C}\right)$.

Concentrations of chemical constituents in water are given either in milligrams per liter (mg/L)

or micrograms per liter ( $\mu \mathrm{g} / \mathrm{L})$. 


\section{Abbreviations}

$\begin{array}{ll}\text { CA DWR } & \text { California Department of Water Resources } \\ \text { CAWSC } & \text { California Water Science Center } \\ \text { EM } & \text { electromagnetic } \\ \mu \mathrm{m} & \text { micrometer } \\ \text { NWIS } & \text { National Water Information System } \\ \text { NWQL } & \text { National Water Quality Laboratory } \\ \text { PVC } & \text { polyvinyl chloride } \\ \text { SP } & \text { spontaneous potential } \\ \text { VOC } & \text { volatile organic compound } \\ \% & \text { per mil - part per thousand } \\ \delta D & \text { isotopic ratio of deuterium }\left[{ }^{2 H}\right] \text { to protium }\left[{ }^{1} \mathrm{H}\right] \text { relative to the ratio in a } \\ & \text { standard reference material, in per mil } \\ \delta^{18} 0 & \left.\text { isotopic ratio of oxygen-18 [ }{ }^{18} \mathrm{O}\right] \text { to oxygen-16 }\left[{ }^{16} \mathrm{O}\right] \text { relative to the ratio }\end{array}$




\section{System Well-Numbering}

Wells and springs are identified and numbered by the State of California according to their location in the rectangular system for the subdivision of public lands. Identification consists of the township number, north or south; the range number, east or west; and the section number. Each section is divided into sixteen 40-acre tracts lettered consecutively (except I and 0 ), beginning with " $A$ " in the northeast corner of the section and progressing in a sinusoidal manner to " $\mathrm{R}$ " in the southeast corner. Within the 40 -acre tract, wells are sequentially numbered in the order they are inventoried. The final letter refers to the base line and meridian. In California, there are three base lines and meridians_-Humbolt (H), Mount Diablo (M), and San Bernardino (S). Because all wells in the study areas of this report are referenced to the San Bernardino base line and meridian, the final letter " $S$ " will be omitted. Well numbers consist of 15 characters and follow the format 001S005W-12L001S. Multiple-well sites are numbered from deepest to shallowest. In this report, well numbers are abbreviated and written as 1S/5W-12L1, or wells are referred to by their common name. The following diagram of the well-numbering system shows how well number $1 \mathrm{~S} / 5 \mathrm{~W}-12 \mathrm{~L} 1$ is derived.

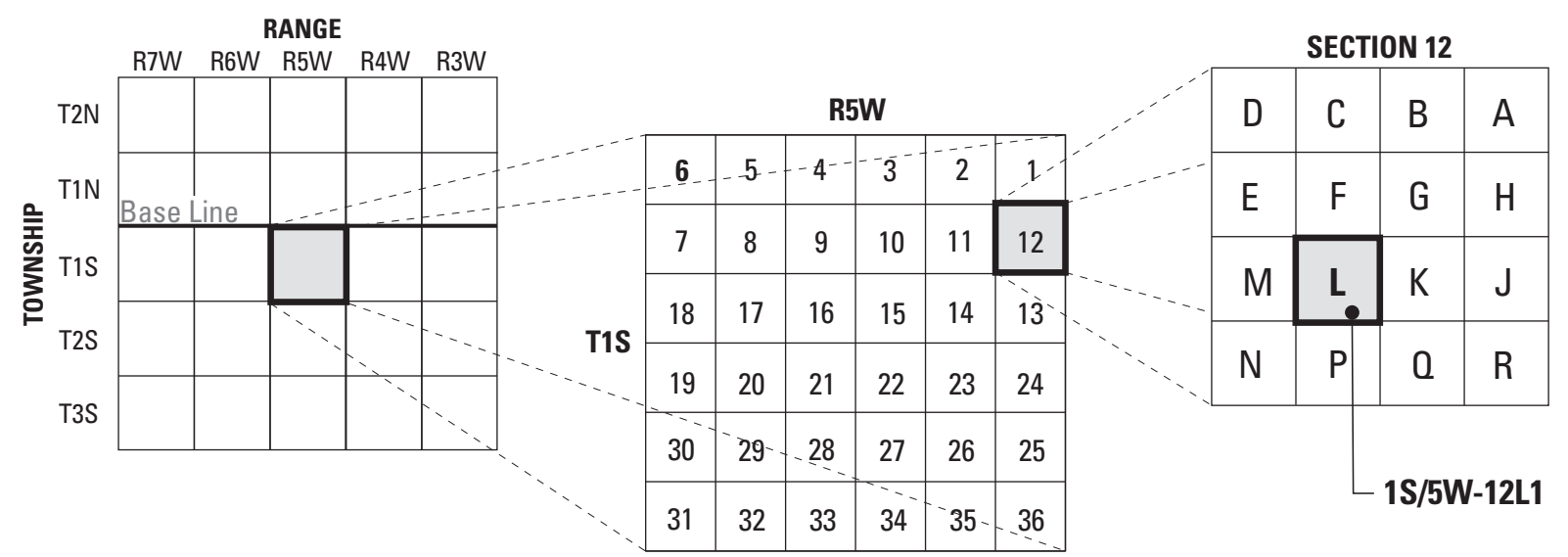




\section{Acknowledgments}

The U.S. Geological Survey would like to acknowledge the staffs of the San Bernardino Valley Municipal Water District and the West Valley Water District for continued support of this study. Raymond Brown, formerly of the San Bernardino Valley Municipal Water District, and Anthony Araiza and Kenneth Sikorski, West Valley Water District, are acknowledged for their logistical contributions.

Rhett Everett of the U.S. Geological Survey and Joseph Montrella, formerly of the U.S. Geological Survey, are acknowledged for help with fieldwork, including but not limited to drilling, geophysical logging, and well development. High-resolution temperature logs were done by Frederick Grubb and Colin Williams of the U.S. Geological Survey. Water levels were measured by Gregg Lobdell and James Nelson, formerly of the U.S. Geological Survey. Anthony Poiriez and Matt Fontanesi, formerly of the USGS, also assisted with the data collection and well development. The U.S. Geological Survey Western Research Drilling Operation is acknowledged for borehole drilling and construction. 


\section{Contents}

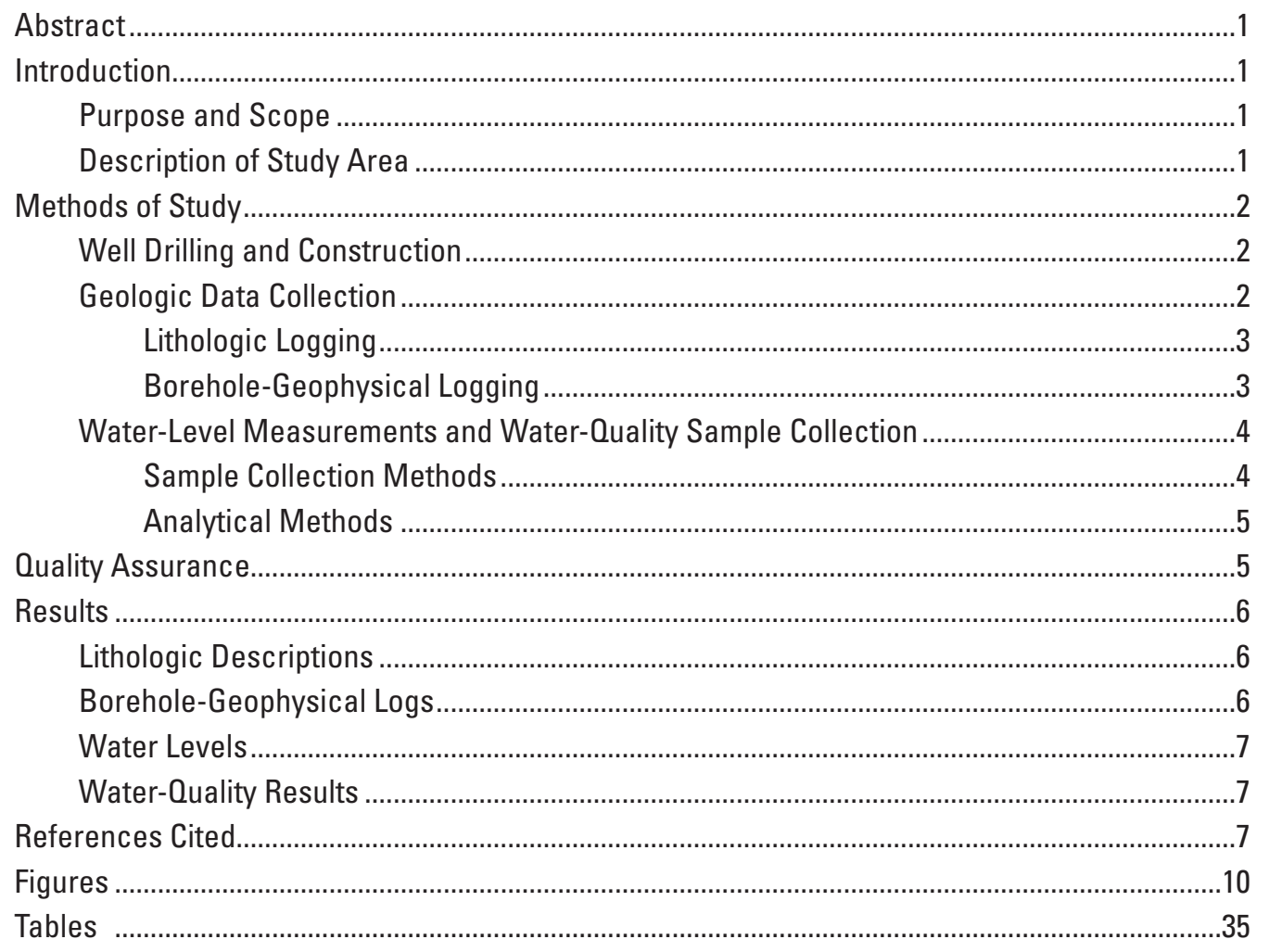




\section{Figures}

1. Map showing location of study area and geologic and other features, San Bernardino County, California..

2. Map showing locations of multiple-well monitoring sites, San Bernardino County, California.....

3. Figure showing typical multiple-well monitoring site completion and construction ......13

4. Graphs showing geophysical logs, well-construction diagrams, and generalized lithologic descriptions for multiple-well monitoring sites, San Bernardino County, Calif. $A$, RCZ6; $B$, RCNE; $C$, RCSW; $D$, CRCR; $E$, RHSW; F, FOG1; G, FOG2...........14

5. Diagrams showing grain-size classification chart.

6. Graphs showing water-level elevation in multiple-well monitoring site RCZ6, San Bernardino County, California.

7. Graph showing water-level elevation in multiple-well monitoring site RCNE, San Bernardino County, California...

8. Graph showing water-level elevation in multiple-well monitoring site RCSW, San Bernardino County, California.

9. Graphs showing water-level elevation in multiple-well monitoring site CRCR, San Bernardino County, California.

10. Graphs showing water-level elevation in multiple-well monitoring site RHSW, San Bernardino County, California.

11. Graph showing water-level elevation in multiple-well monitoring site FOG1, San Bernardino County, California.

12. Graph showing water-level elevation in multiple-well monitoring site FOG2, San Bernardino County, California.

13. Diagrams showing major-ion chemistry of water from multiple-well monitoring site RCZ6, San Bernardino County, California, 2011

14. Diagrams showing major-ion chemistry of water from multiple-well monitoring site CRCR, San Bernardino County, California, 2007.

15. Diagrams showing major-ion chemistry of water from multiple-well monitoring site RHSW, San Bernardino County, California, 2007

16. Diagrams showing major-ion chemistry of water from multiple-well monitoring site FOG1, San Bernardino County, California, 2007.

17. Diagrams showing major-ion chemistry of water from multiple-well monitoring site FOG2, San Bernardino County, California, 2007.

18. Graph showing delta oxygen-18 and delta deuterium composition of water from multiple-well monitoring site RCZ6, San Bernardino County, California, 2011

19. Graph showing delta oxygen-18 and delta deuterium composition of water from multiple-well monitoring site CRCR, San Bernardino County, California, 2007

20. Graph showing delta oxygen-18 and delta deuterium composition of water from multiple-well monitoring site RHSW, San Bernardino County, California, 2007.

21. Graph showing delta oxygen-18 and delta deuterium composition of water from multiple-well monitoring site F0G1, San Bernardino County, California, 2007.

22. Graph showing delta oxygen-18 and delta deuterium composition of water from multiple-well monitoring site FOG2, San Bernardino County, California, 2007. 


\section{Tables}

1. Well-identification and construction information for multiple-well monitoring sites, San Bernardino County, California

2. Lithologic log from sieved drill cuttings (125- $\mu \mathrm{m}$ screen opening) from multiple-well monitoring site RCZ6, San Bernardino County, California

3. Lithologic log from shaker drill cuttings (250- $\mu \mathrm{m}$ screen opening) from multiple-well monitoring site RCZ6, San Bernardino County, California

4. Lithologic log from sieved drill cuttings (125- $\mu \mathrm{m}$ screen opening) from multiple-well monitoring site RCNE, San Bernardino County, California

5. Lithologic log from shaker drill cuttings (250- $\mu \mathrm{m}$ screen opening) from multiple-well monitoring site RCNE, San Bernardino County, California

6. Lithologic log from sieved drill cuttings (125- $\mu \mathrm{m}$ screen opening) from multiple-well monitoring site RCSW, San Bernardino County, California

7. Lithologic log from shaker drill cuttings (250- $\mu \mathrm{m}$ screen opening) from multiple-well monitoring site RCSW, San Bernardino County, California

8. Lithologic log from sieved drill cuttings (125- $\mu \mathrm{m}$ screen opening) from multiple-well monitoring site CRCR, San Bernardino County, California

9. Lithologic log from shaker drill cuttings (250- $\mu \mathrm{m}$ screen opening) from multiple-well monitoring site CRCR, San Bernardino County, California

10. Lithologic log from sieved drill cuttings (125- $\mu \mathrm{m}$ screen opening) from multiple-well monitoring site RHSW, San Bernardino County, California

11. Lithologic log from shaker drill cuttings (250- $\mu \mathrm{m}$ screen opening) from multiple-well monitoring site RHSW, San Bernardino County, California

12. Lithologic log from sieved drill cuttings (125- $\mu \mathrm{m}$ screen opening) from multiple-well monitoring site F0G1, San Bernardino County, California

13. Lithologic log from shaker drill cuttings $(250-\mu \mathrm{m}$ screen opening) from multiple-well monitoring site FOG1, San Bernardino County, California

14. Lithologic log from sieved drill cuttings (125- $\mu \mathrm{m}$ screen opening) from multiple-well monitoring site FOG2, San Bernardino County, California

15. Lithologic log from shaker drill cuttings $(250-\mu \mathrm{m}$ screen opening) from multiple-well monitoring site FOG2, San Bernardino County, California

16. Date range of available water-level data, count of water-level measurements, and maximum and minimum water-level elevations for select wells, San Bernardino County, California.

17. Field measurement, major-ion, nutrient, and selected trace-element data in groundwater samples from selected monitoring sites, San Bernardino County, California .

18. Deuterium, oxygen-18, and tritium data in groundwater samples from selected monitoring sites, San Bernardino County, California.. 


\title{
Geohydrologic and Water-Quality Data in the Vicinity of the Rialto-Colton Fault, San Bernardino, California
}

\author{
By Nick Teague, Anthony A. Brown, and Linda R. Woolfenden
}

\section{Abstract}

The Rialto-Colton Basin is in western San Bernardino County, about 60 miles east of Los Angeles, California. The basin is bounded by faults on the northeast and southwest sides and contains multiple barriers to groundwater flow. The structural geology of the basin leads to complex hydrology. Between 2001 and 2008, in an effort to better understand the complex hydrologic system of the Rialto-Colton Basin, seven multiple-well monitoring sites were constructed. Two to six observation wells were installed in the borehole at each site; a total of 32 observation wells were installed. This report presents geologic, hydrologic, and water-quality data collected from these seven multiple-well monitoring sites.

Descriptions of the collected drill cuttings were compiled into lithologic logs for each monitoring site. The lithologic logs are summarized along with the geophysical logs, including gamma-ray, spontaneous potential, resistivity, and electromagnetic induction tool logs. At selected sites, sonic tool logs also were recorded. Periodic water-level measurements are reported, and water-level data are displayed on hydrographs. Water levels at multiple-well monitoring sites in the northern part of the study area differed between the shallow and deep observation wells; in the remaining multiple-well monitoring sites, water levels differed little with depth. Along the southern trace of the Rialto-Colton Fault, water levels are slightly higher east of the fault than west of the fault. Selected water-quality data for 21 of the observation wells show water from wells in the northern and central parts of the study area is calcium-carbonate water. In the southern part of the study area, water from wells screened above 400 feet below land surface is of mixed type or is calcium-carbonate water. Water from wells screened greater than 400 feet below land surface in the southern part of the study area is sodium-carbonate or sodium-mixed anion water. Water from most wells in the study area plots above the Global Meteoric Water Line along an apparent local meteoric water line, indicating the water has not experienced substantial evaporation before infiltration. A few samples from shallow wells in the study area plot slightly to the right of the Global Meteoric Water Line, possibly indicating the water experienced some evaporation before recharge.

\section{Introduction}

The Rialto-Colton Basin is in western San Bernardino County, about 60 miles (mi) east of Los Angeles, California (fig. 1). The basin is bounded on two sides by faults, the Rialto-Colton Fault in the southwest and the San Jacinto Fault in the northeast, and contains multiple barriers to groundwater flow. While movement of water within the basin generally is northwest to southeast, uncertainty exists regarding hydrologic conditions adjacent to the faults and barriers. The U.S. Geological Survey (USGS) was asked by the San Bernardino Valley Municipal Water District and the West Valley Water District to collect geologic, water-level, and water-quality data in areas of hydrologic uncertainty to improve understanding of the overall basin hydrology. This project is being done by the USGS in cooperation with both water districts.

\section{Purpose and Scope}

The purpose of this work was to establish new multiplewell monitoring sites within the Rialto-Colton Basin and in the adjacent Chino Basin. The scope of the work included drilling and installing seven multiple-well monitoring sites within the Rialto-Colton and Chino Basins, describing the lithology through well cuttings and borehole geophysics, monitoring water levels, and water-quality sampling and analysis. At each site, two to six observation wells were installed at isolated depths in the boreholes. Wells were drilled for the purpose of collecting data to be used in future investigative reports. This report includes site-location, well-construction, geologic, hydrologic, and water-quality data collected from the observation wells during 2001-11.

\section{Description of Study Area}

The Rialto-Colton Basin is a northwest-southeast trending alluvial basin in the upper Santa Ana River watershed. As defined by the California Department of Water Resources (CA DWR), the 47-square miles ( $\left.\mathrm{mi}^{2}\right)$ Rialto-Colton Basin 
is bounded on the northeast by the Barrier E and San Jacinto Faults and on the southwest by the Rialto-Colton Fault and the Chino Basin (California Department of Water Resources, 2003) (fig. 1). The San Gabriel Mountains form the northwestern boundary, and the Badlands and Box Spring Mountains form the southeastern boundary. The Santa Ana River traverses the southeastern part of the basin. Warm, San Timoteo, and Lytle Creeks join the Santa Ana River near the southeastern boundary of the basin (fig. 1). An unnamed fault trends northwest to southeast, subparallel to the San Jacinto Fault, dissecting the Rialto-Colton Basin. In the northwestern part of the basin, Barrier J trends southwest to northeast. The unnamed fault and Barrier $\mathrm{J}$ act as barriers to groundwater flow; however, groundwater may flow in the unfaulted parts of the alluvium (Woolfenden and Kadhim, 1997) (fig. 1). Groundwater moves predominantly southeastward from Barrier J toward the city of Colton and then westward to southwestward in the southern end of the basin; groundwater eventually drains into the adjacent Chino Basin (Dutcher and Garrett, 1963).

\section{Methods of Study}

Seven multiple-well monitoring sites were installed to collect geologic, hydrologic, and water-quality data. Lithologic and borehole-geophysical data were collected from test holes drilled for this study, water levels were measured from wells installed in these test holes, and water-quality samples were collected and analyzed for selected constituents. The lithology of each test hole was described in brief from the drill cuttings during drilling and in more detail after samples of the cuttings were collected. Borehole-geophysical surveys were conducted after the drilling of each test hole was completed. The depth and perforated interval of the observation wells installed in the test holes were determined on the basis of the lithologic and borehole-geophysical data and existing data from nearby wells. Water levels were measured and water-quality samples for selected constituents were collected periodically after construction and development of each well was completed.

\section{Well Drilling and Construction}

During 2001-08, four multiple-well monitoring sites were installed in the Rialto-Colton Basin, and three multiplewell monitoring sites were installed in the Chino Basin, adjacent to the Rialto-Colton Fault (fig. 2, table 1). Monitoring site RCNE (1N/6W-26A) is in the Chino Basin but lies east of the Rialto-Colton Fault as described by Anderson and others (2004). The locations of the multiple-well monitoring sites were chosen where depth-dependent lithologic, borehole-geophysical, water-level, and water-quality data were not available. Consideration also was given to locating the multiple-well monitoring sites on public property having easy access that would allow subsequent water-level monitoring. Sites RCNE (1N/6W-26A), RCSW (1N/6W-26K), FOG1 (1S/4W-29H), and FOG2 (1S/4W-29K) were specifically selected to collect geologic data on each side of the RialtoColton Fault and to establish monitoring sites that could provide key data leading to a better understanding of the movement of groundwater across this barrier. RCNE (1N/6W-26A) and RCSW (1N/6W-26K) were sited on either side of the northwestern part of the Rialto-Colton Fault to determine if flow occurs across a portion of the fault in this area; FOG1 (1S/4W-29H) and FOG2 (1S/4W-29K) were sited near the Santa Ana River where most groundwater flow is believed to cross the Rialto-Colton Fault. A diagram showing the well construction of a typical installation of a multiple-well monitoring site is shown in figure 3.

The multiple-well monitoring sites were drilled by the USGS Western Region Research Drilling Operation using a mud-rotary method. The diameters of the test holes decreased with depth and ranged from 6 to 12.25 inches (in.). After total hole depth was attained, borehole-geophysical logs were recorded for each test hole before observation wells were completed. Two to six observation wells were installed in each hole. The monitoring wells were constructed by using flush-threaded, 2-in.-diameter, schedule 80 polyvinyl chloride (PVC) casing. The screened interval for each monitoring well typically consisted of a 20 -ft section of slotted PVC (slot size is $0.020 \mathrm{in}$.) at the bottom. At sites RCZ6 (1N/5W-17L), RCNE (1N/5W-26A), RCSW (1N/6W-26K), and FOG1 (1S/4W-29H), a sump was added to the well below the screen.

Once casing was installed to the desired depth for the deepest observation well, bentonite grout was tremied around the casing below the screened interval (fig. 3). Next, a filter pack of No. 3 Monterey sand was tremied around the screened interval. Bentonite grout was then tremied in place, above the filter pack, to seal the borehole and effectively isolate the screened interval of the monitoring well. The process was repeated for each successive well. Finally, a traffic-rated vault was installed at land surface to secure the completed wells. Diagrams of the well construction for the multiple-well monitoring sites are shown in figures $4 A-G$, and the wellconstruction data are given in table 1 .

After installation was completed, the wells were developed by evacuating residual drilling fluid using compressed air. Extensive airlifting and a surging technique with compressed air were employed to further develop the filter pack surrounding the well. Specific conductance, $\mathrm{pH}$, temperature, apparent color, and turbidity, along with the discharge rate and total volume, were monitored during this process. Development was continuous until no discernible drilling mud was present in the lifted water and field measurements of $\mathrm{pH}$ and specific conductance had stabilized. 


\section{Geologic Data Collection}

The geologic data collected for each of the seven multiple-well sites include information assembled from various lithologic logging techniques and borehole-geophysical logging tools. The methods used in collecting lithologic and geophysical data are presented separately below.

\section{Lithologic Logging}

Generalized lithologic logs (figs. 4A-G) were compiled from field descriptions and subsequent laboratory microscope examination of drill cuttings, notes on drilling rates and action, and geophysical logs at the seven multiple-well monitoring sites (fig. 2, table 1). Drill cuttings were obtained in two ways: collection from the return drilling fluid throughout each $20-\mathrm{ft}$ interval by using a number 120 (125 micrometers; $\mu \mathrm{m})$ U.S.A. Standard Testing Sieve and grab sampling every $10 \mathrm{ft}$ from the number $60(250 \mu \mathrm{m})$ shaker screen through which return drilling fluid passes. The sieved samples represent a composite of sand-sized, silt-sized, and finer-textured materials (which tend to form balls of clay) from each 20 -foot (ft) drilling interval. Grab samples collected from the shaker screen represent texture fractions typically coarser than the sieve samples. Laboratory microscope examination of drill cuttings helped to more accurately define the field description with respect to sediment type, percent fine-textured and coarse-textured sediment, sorting, roundness, and color (Folk, 1954). Texture descriptions of sieve and shaker cuttings were described by using standardized grain-size classification (fig. 5; Lane, 1947). For samples containing gravel, the terms "silt" and (or) "clay" are used in lieu of "mud." Color, determined on moist samples, follows the numerical color designations in Munsell Soil Color Charts (Munsell Color, 1994). Lithologic descriptions of sieve and shaker samples are provided separately in this report (tables 2-15). Sieve and shaker samples used to compile generalized lithologic descriptions for each monitoring site are shown on figures $4 A-G$. The depths of contacts between lithologic units were refined by comparison to geophysical logs.

\section{Borehole-Geophysical Logging}

Borehole-geophysical logs were used in conjunction with the lithologic descriptions to select screened intervals during construction of observation wells (figs. $4 A-G$ ) at the seven multiple-well monitoring sites (fig. 2, table 1). Boreholegeophysical logs were collected in the uncased, mud-filled open hole before wells were installed. The logs provide additional information about the lithologic material and chemical properties of the groundwater. Borehole-geophysical logs collected include caliper, temperature and temperature gradient, natural gamma and spontaneous potential (SP), normal resistivity (16- and 64-in.), lateral resistivity and conductivity, and sonic data. Sonic logs were obtained at all sites except RCSW (1N/6W-26K) because the tool was unavailable when that site was logged. The geophysical tools were calibrated as specified by the manufacturer, except for the caliper tool that was calibrated onsite according to the diameters of the drill bits used to drill the borehole.

Down-hole caliper logging tools are designed to measure the inside diameter of the open borehole. This allows for the detection of any "wash-out zones" where unconsolidated sand has been washed away by the drilling process. The caliper tool also can aid in identifying zones in which a clay unit has expanded owing to a decrease in down-hole pressure. In addition, the caliper tool is used to determine the quantity of sand and grout needed to fill the annular space during the construction of the observation wells.

High-resolution borehole temperature logs were collected in the deepest well at each multiple-well monitoring site, except RCZ6 (1N/5W-17L). When well RCZ6 (1N/5W-17L) was drilled, the high-resolution temperature log tool was not available for logging in the area; therefore, the electrical tool was used to log groundwater temperature at well RCZ6 $(1 \mathrm{~N} / 5 \mathrm{~W}-17 \mathrm{~L})$. To ensure the water temperature was characteristic of ambient groundwater conditions, logging was performed several months after the site had been constructed, developed, and sampled for water quality to allow sufficient time for the water column in the well to equilibrate with the surrounding material. Generally, groundwater temperature increases with depth, and the global average is about $25^{\circ}$ degrees Celsius $\left({ }^{\circ} \mathrm{C}\right)$ per kilometer $(\mathrm{km})$. The geothermal gradient in sedimentary basins generally exceeds this average because of the relatively low thermal conductivity of sedimentary materials (Ingebritsen and Sanford, 1998). Perturbations in the geothermal gradient in temperature logs can provide information about geologic formations as well as horizontal and vertical patterns of groundwater flow. Groundwater temperature is related to lithology (which affects thermal conductance), depth, recharge source, and residence time within the aquifer (Keys and MacCary, 1971; Beck, 1976; Michalski, 1989; Williams and others, 1994). Measured temperature logs, when expressed as a measured vertical temperature gradient and compared with the geothermal gradient, can be used to identify potential zones of relatively greater groundwater flow. Depth intervals where the temperature gradient is rightward convex upward, or decreases in the temperature gradient, are consistent with the cooling influence of groundwater flow through relatively permeable units. Depth intervals exhibiting greater temperature perturbations can be interpreted as zones of greater flow.

The natural gamma tool measures the intensity of gamma-ray emissions resulting from the decay of naturally occurring radioactive isotopes, including 
potassium-40, uranium-238, uranium-235, and thorium-232 (Schlumberger, 1972). Natural gamma logs are used to correlate lithology between wells and define aquifer thickness. Clay-rich deposits and feldspar-rich gravels generally emit higher intensity gamma rays than silts or sands.

SP, normal resistivity (16- and 64-in.), and lateral resistivity are electric logs that measure the electrical properties of the formation around the borehole and the fluid in the formation. These logs are used to distinguish fine-grained silt and clay from coarser sand and gravel. The SP tool measures voltage differences that exist between different layers, which aids in determining bed thickness, clay content, and lithology. On SP logs, lithologic contacts are located at the point of curve inflection. Differences in salinity of the drilling fluid and formation water affect SP logs. When the drilling fluid is less saline than the formation water, maximum positive (to the right) deflections represent intervals of fine-grained material, mostly clay; negative deflections represent coarser sediments (Schlumberger, 1972). When the drilling fluid is more saline than the formation water, the signal is reversed, as generally was the case in this study.

Normal and lateral electrical resistivity tools measure the apparent resistivity of a volume of rock under the direct application of an electric current (Keys and MacCary, 1971). These logs are used to determine formation and fluid resistivity and to estimate formation porosity. Low resistivity generally indicates water higher in dissolved solids or fine-grained deposits such as silt, clay, and shale, or both. High resistivity indicates water lower in dissolved solids or coarser material such as sand or gravel, or both. Two types of normal resistivity were measured, 16-in. (referred to as short) and 64-in. (referred to as long). The difference between the short- and long-normal $\operatorname{logs}$ is the separation distance between the electrodes in the tool. As the separation distance increases, the volume of aquifer material measured by the tool increases. Comparison of short- and long-normal resistivity values can provide an estimate of the extent to which drilling fluid has entered aquifer deposits, an indication of the permeability of the aquifer deposits. Lateral resistivity logs are made using a tool similar to the normal resistivity tool, only the spacing between the electrodes is longer. The longer spacing between the electrodes is designed to measure resistivity further beyond the borehole than normal resistivity tools.

The electromagnetic (EM) tool measures the conductivity of a volume of rock under an induced electromagnetic field, shown as conductivity logs on figures $4 A-G$. Conductivity logs yield information on lithology of a formation and on chemical characteristics of pore water (McNeill, 1986). In alluvial aquifers, high conductivity generally indicates water higher in dissolved solids or fine-grained deposits such as silt, clay, and shale, or both. Low conductivity indicates water lower in dissolved solids or coarse-grained material such as sand or gravel, or both. Conductivity logs produced using the EM induction tool can help identify water-bearing units to determine optimum depths for the placement of monitoring well screens.
Sonic tools measure the velocity of an acoustic pulse between a transmitter and a receiver. The sonic tool used has two receivers, near and far, that record the arrival time of the compressional sound wave sent by the transmitter. Sonic logs display the difference in arrival times between the receivers, delta $t$, which can be related to the physical properties of the adjacent material. The sonic log gives an indication of the degree of consolidation of the formation, as well as an approximate location of the water table. Increasing consolidation and the location of the water table are indicated by decreased delta t.

\section{Water-Level Measurements and Water-Quality Sample Collection}

Water levels were measured periodically (typically monthly) at the monitoring sites and also prior to collection of the water-quality sample. Water levels were measured and recorded to within $0.01 \mathrm{ft}$ using a calibrated electric tape.

A total of 53 water-quality samples were collected from 22 of the 32 observation wells from 2002 to 2011. Some wells could not be sampled because the wells were dry or the yields were too small to produce a sufficient volume of water for sampling. Water samples from well RCNE-2 (1N/6W-26A2) had high concentrations of phosphate, indicating the well was not adequately developed and drilling mud was still entrapped within the formation; therefore, water-quality data from the sample collected at well RCNE-2 (1N/6W-26A2) are not presented in this report. A total of 41 water-quality samples were collected for analysis of major ions, trace elements, and nutrients; 21 for analysis of stable isotopes of water (oxygen- 18 and deuterium); 23 for analysis of carbon 13/12 isotopic ratios and carbon-14 isotope; 46 for analysis of tritium; and 18 for analysis of volatile organic compounds (VOCs).

The field parameters - specific conductance, $\mathrm{pH}$, temperature, dissolved oxygen, and alkalinity - were measured during the collection of the water-quality sample.

\section{Sample Collection Methods}

Groundwater samples at 22 wells were collected in accordance with the protocols established by the USGS National Field Manual for the Collection of Water-Quality Data (U.S. Geological Survey, 2006). A minimum of three casing volumes were purged from each well before sampling using a portable submersible pump. Prior to purging and sample collection, sampling equipment, including pumps, were cleaned in accordance with the USGS National Field Manual for the Collection of Water-Quality Data (Wilde, 2004). The field parameters - specific conductance, $\mathrm{pH}$, and temperaturewere monitored during purging. Water-quality samples were collected only after monitored field parameters had stabilized. Stability was attained when three successive measurements at intervals of 5 minutes or more differed by less than 5 percent for specific conductance, 0.1 units of $\mathrm{pH}$, and $0.2^{\circ} \mathrm{C}$ for water 
temperature. Instruments used for the measurements of specific conductance and $\mathrm{pH}$ were calibrated in the field during the initial purging process and prior to sampling. Water temperature was measured using the built-in thermistor on the $\mathrm{pH}$ probe (plus or minus $0.1^{\circ} \mathrm{C}$ ). The thermistor was frequently checked against a National Institute of Standards and Technology certified mercury thermometer and conformed to within $0.5^{\circ} \mathrm{C}$. Measurements of dissolved oxygen were determined by using the Alsterberg-Azide modified Winkler titration method and the membrane electrode method, as described in the USGS National Field Manual for the Collection of Water-Quality Data (Lewis, 2006). Measurements of dissolved oxygen were processed in the field immediately preceding sampling. Alkalinity was determined in the field by incrementally titrating filtered samples with dilute sulfuric acid, using a digital titration system, as described in the USGS National Field Manual for the Collection of Water-Quality Data (Rounds, 2006). Concentrations of bicarbonate and carbonate were computed using a speciation model available at $h t t p: / /$ or.water.usgs.gov/alk/ (U.S. Geological Survey, variously dated).

During sample collection, purge water from the pump was diverted through a Teflon tube into a sample-collection chamber that minimized atmospheric exposure. All sampling and filter apparatuses were rinsed thoroughly with sample water prior to sample collection. Water samples intended for analyses of major ions, nutrients, trace elements, and alkalinty were filtered in the field through a polyethersulfone membrane capsule filter with a pore size of $0.45 \mu \mathrm{m}$. Sample bottles were rinsed three times with sample water prior to filling. Samples for nutrient analysis were collected in opaque polyethylene bottles and preserved on ice to inhibit bacterial growth. Samples for the determination of cations and selected trace elements were collected in acid-rinsed polyethylene bottles and then acidified with ultrex-grade nitric acid to a $\mathrm{pH}$ less than 2. Samples for anion determination were collected in a polyethylene bottle and did not require preservation.

Unfiltered samples for the analysis of the stable isotopes of water (deuterium, oxygen-18/16) and tritium were collected in 60-milliliter $(\mathrm{mL})$ glass and 1-liter $(\mathrm{L})$ polyethylene bottles, respectively, and sealed with black phenolic caps with conical-shaped polyethylene liners to minimize exchange with the atmosphere. Samples for the analysis of carbon-13/12 and carbon-14 isotopes were collected by bottom filling and overflowing a 1-L plastic-coated, amber glass bottle with several volumes of filtered water. Samples were sealed with either poly-seal polyethylene caps or special Teflon-septa caps with no air space in the bottle and held on ice. VOCs were collected as unfiltered water in 40-mL amber glass bottles at selected wells using sampling and preservation protocols of the USGS National Field Manual for the Collection of Water-Quality Data (Wilde and others, 2004).

\section{Analytical Methods}

Samples were shipped to the USGS National Water Quality Laboratory (NWQL) in Denver, Colorado, for analysis of inorganic substances following standard methods outlined by Fishman and Friedman (1989), analysis of organic substances following standard methods outlined by Fishman (1993), analysis of metals following standard methods outlined by Faires (1993), analysis of total phosphorus following standard methods outlined by Patton and Truitt (1992) and Jones and Garbarino (1999), and analysis of arsenic and selenium following standard methods outlined by Struzeski and others (1996).

Samples for the analysis of stable isotopes were shipped to the USGS Stable Isotope Laboratory in Reston, Virginia, to be analyzed using methods described by Coplen and others (1991) and Epstein and Mayeda (1953). Tritium samples were analyzed at the University of Miami Rosenstiel School of Marine and Atmospheric Science (RSMAS) Tritium Laboratory in Miami, Florida, using methods described by Thatcher and others (1977).

Samples for carbon-13/12 and carbon-14 isotopes were analyzed by the University of Waterloo Environmental Isotope Laboratory in Ontario, Canada, or the National Ocean Sciences Accelerator Mass Spectrometry Facility (NOSAMS) in Woods Hole, Massachusetts, using methods described by Gleason and others (1969), Stuiver and Polach (1977), and Beukens (1992).

VOC samples were analyzed at the NWQL in Denver, Colo., by gas chromatography/mass spectrometry methods described by Connor and others (1998).

\section{Quality Assurance}

Several methods were used to analyze the quality of the sample data within this report, including collection and interpretation of quality-control (QC) samples, calculation of major-ion charge balances, and analysis of trends in constituent proportionality for samples collected from the same wells on different dates.

QC samples were collected to quantify bias and estimate potential variability associated with the sample collection, processing, and laboratory analysis. Samples include a source solution blank, two equipment blanks, two field blanks, and a sequential field replicate; these QC samples were collected following procedures outlined by the USGS National Field Manual for the Collection of Water-Quality Data (U.S. Geological Survey, 2006). The equipment blanks were collected at the California Water Science Center (CAWSC) office under controlled conditions; all other QC samples were collected in the field. Blanks were analyzed to identify contamination 
of routine groundwater samples by field personnel, sampling equipment, sample bottles, or any other source of contamination during transportation of field equipment, during shipment to the laboratory, or during analysis at the laboratory. Blank samples were analyzed for VOCs and gasoline oxygenates only under a custom schedule having slightly lower reporting limits for many analytes than the analyses used for groundwater samples. VOCs and gasoline oxygenates were not detected in any blank samples, indicating no bias in VOC results caused by sample collection. A replicate was collected to assess variability of the sample-collection process and analysis for VOCs. Samples with a relative error less than 15 percent are generally considered acceptable. The relative error was less than 1 percent for the replicate sample collected for all analytes. Precision of the stable isotopes deuterium and oxygen-18 are better than \pm 2.0 and 0.2 per mil, respectively.

Major-ion charge balances between positively (cations) and negatively (anions) charged ions were calculated for each sample. An imbalance less than or equal to 5 percent was considered to be within an acceptable limit. Of the 44 samples, 20 percent have a charge imbalance greater than the acceptable limit. Of those samples that exceed the acceptable limit, only one sample had a charge imbalance greater than 10 percent. Only samples that have charge imbalances below the acceptable limit are displayed in this report, excluding the samples from wells RCZ6-5 (1N/5W-17L5) and RCZ6-6 (1N/5W-17L6). The samples from wells RCZ6-5 (1N/5W-17L5) and RCZ6-6 (1N/5W-17L6) had charge balances slightly greater than the acceptable limit, 7.72 and 7.36 percent, respectively, but were the only samples available for those wells.

For wells sampled more than once, trends in constituent proportionality, including sodium/chloride, potassium/fluoride, sum of cations/specific conductance, and sum of anions/specific conductance, were evaluated. Use of constituent proportionalities to evaluate the variability of sampling results has some uncertainties because groundwater chemistry can change over time as is evident over multiple decades in the RialtoColton and adjacent basins (Kent and Landon, 2013). The variability is expressed in relative percent difference (RPD) between the replicate analyses of the same environmental sample as follows:

$$
R P D=\frac{\left(C_{1}-C_{2}\right)}{\left(C_{1}+C_{2}\right) / 2} \times 100 \text { percent }
$$

where

$$
\begin{aligned}
& \mathrm{C}_{1} \text { is the concentration in the first sample, and } \\
& \mathrm{C}_{2} \text { is the concentration in the second sample of } \\
& \text { the replicate pair. }
\end{aligned}
$$

Samples with a RPD less than 20 percent were considered as evidence of reasonable reproduceability. RPDs greater than 20 percent were calculated for sodium/chloride in 32 percent of the wells and for potassium/fluoride in 32 percent of the wells; for these ratios in particular, the differences over time may be influenced by actual changes in groundwater chemistry. However, the RPDs were less than 20 percent for calculations of sum of cations/specific conductance in all the wells and for sum of anions/specific conductance in 95 percent of the wells; these measures are more unlikely to change over time, and the results suggest measured sample results generally showed reasonable reproducibility over time.

\section{Results}

Users of the data presented in this report are encouraged to access information through the National Water Information System NWISWeb at http://water.usgs.gov/nwis. NWISWeb serves as an interface to a database network of site information, real-time, groundwater, surface-water, and water-quality data collected from locations throughout the 50 states and elsewhere. Data are updated in NWISWeb from the database network on a regularly scheduled basis. For electronic versions of this report, NWISWeb water-quality data for each multiple-well monitoring site can be accessed through the respective web address hyperlinks located in table 16 , and NWISWeb water-level data can be accessed through the web address hyperlinks embedded in the respective hydrographs. Data presented in this report include lithologic descriptions, borehole-geophysical data, water-level data, and water-quality data.

\section{Lithologic Descriptions}

Lithologic descriptions of sieve and shaker samples are provided separately in this report (tables $2-15$ ). Sieve and shaker sample lithologic descriptions were used in compiling the generalized lithology for each multiple-well monitoring site shown on figures $4 A-G$. Lithologic logs indicate subsurface materials are largely heterogeneous alluvium. Grain size ranged from clay to gravel. Sites FOG1 (1S/4W-29H) and FOG2 (1S/4W-29K) were drilled through alluvium into bedrock. Most sites show a coarsening upward. Site RCZ6 $(1 \mathrm{~N} / 5 \mathrm{~W}-17 \mathrm{~L})$ had the greatest amount of fines with thick clay layers interspersed throughout the depth profile. Other than at site RCZ6 (1N/5W-17L), grain size in the northern part of the study area was coarser than in the south.

\section{Borehole-Geophysical Logs}

Geophysical logs for each multiple-well monitoring site are shown in figures $4 A-G$. The $\mathrm{SP} \log$ is presented with the natural gamma log, and the conductivity $\log$ is presented with the lateral resistivity log. The geophysical logs varied by location, including across the Rialto-Colton Fault, because of differences in lithology. In general, data from the gamma log, the electric logs, and the conductivity log were consistent with the results from the lithologic data. Additionally, well-defined signals in the temperature gradient, as well as in the sonic logs, were coincident with water levels measured within the wells. 


\section{Water Levels}

The range of dates for which water levels are available, as well as the number of water-level measurements and the maximum and minimum water-level elevations, are presented in table 16 for each well. Water-level data for the multiplewell monitoring sites are presented in figures 6-12. NWISWeb water-level data can be accessed through the web address hyperlinks embedded in the respective hydrographs.

Hydrographs are used to show water levels through time and may also give some insight into the presence of perched aquifers. Water levels at multiple-well monitoring sites in the northern part of the study area differed between the shallow and deep observation wells. Two sets of sites were situated so that the multiple-well sites were on either side of the RialtoColton Fault-RCNE (1N/6W-26A) and RCSW (1N/6W-26K) in the north and FOG1 (1S/4W-29H) and FOG2 (1S/4W-29K) in the south. Along the northern trace of the Rialto-Colton Fault, water levels are higher west of the fault [RCSW $(1 \mathrm{~N} / 6 \mathrm{~W}-26 \mathrm{~W})]$ than east of the fault [RCNE $(1 \mathrm{~N} / 6 \mathrm{~W}-26 \mathrm{~A})]$. Along the southern trace of the Rialto-Colton Fault, water levels are slightly higher east of the fault [FOG1 (1S/4W-29H)] than west of the fault [FOG2 (1S/4W-29K)].

\section{Water-Quality Results}

Water-quality data from 21 of the 22 samples collected from the 32 observation wells from 2002 to 2011 are presented in this report. Nine wells could not be sampled because the wells were dry or the yields were too small to produce a sufficient volume of water for sampling. The sample from well RCNE-2 (1N/6W-26A2) had an anomalously high concentration of phosphate, which indicates the well was not adequately developed and drilling mud was still entrapped within the formation; therefore, water-quality data from the sample collected at well RCNE-2 (1N/6W-26A2) are not presented in this report. Four of the 22 samples had VOC detections at levels that would be difficult to interpret; therefore, VOCs are not presented or discussed further in this report. Field measurements, major-ions, nutrients, and selected trace-element data are presented in table 17. Isotope data are presented in table 18. Isotope data presented in this report represent the dates on which samples for stable isotopes of water, tritium, and carbon-13/12 and carbon-14 isotopes were collected concurrently. Graphical representations of the water-quality data are shown at the back of this report (figs. 13-17).

Trilinear diagrams (figs. 13-17) display water composition with respect to major cations and anions. Water-quality data from wells in the northern and central parts of the study area, RCZ6 (1N/5W-17L), CRCR (1S/5W-03A), and RHSW (1S/5W-13B), plot near the left corner of the central diamond as calcium-carbonate water. In the southern part of the study area, wells screened above $400 \mathrm{ft}$ below land surface [FOG1-4 (1S/4W-29H4), FOG1-5 (1S/4W-29H5), FOG2-2 (1S/4W-29K2), FOG2-3 (1S/4W-29K3), FOG2-4
(1S/4W-29K4), and FOG2-5 (1S/4W-29K5)] have waterquality data that plot in the center or slightly left of the center of the central diamond and are mixed cation-carbonate or mixed cation-mixed anion waters. Water-quality data from wells in the southern part of the study area screened greater than $400 \mathrm{ft}$ below land surface [FOG1-1 (1S/4W-29H1), FOG1-2 (1S/4W-29H2), FOG1-3 (1S/4W-29H3), and FOG2-1 (1S/4W-29K1)] plot down and to the right of the center of the central diamond as sodium-carbonate or sodium-mixed anion waters.

Plots of the ratio of stable isotopes of oxygen $\left(\delta^{18} \mathrm{O}\right)$ and deuterium $(\delta \mathrm{D})$ provide insight into the hydrologic history of the groundwater (figs. 18-22). The isotope ratios are expressed in delta notation $(\delta)$ as per mil (\%o) differences relative to a standard known as Vienna Standard Mean Ocean Water (VSMOW) (Gonfiantini, 1978). Craig (1961) found that a linear relation exists between $\delta \mathrm{D}$ and $\delta^{18} \mathrm{O}$ in meteoric waters throughout the world; this relation is referred to as the Global Meteoric Water Line. Variations in $\delta^{18} \mathrm{O}$ and $\delta \mathrm{D}$ reflect the elevation, temperature, season, or source region of groundwater recharge and the degree of evaporation prior to recharge. Water that has not undergone substantial evaporation will plot near and sub-parallel to the Global Meteoric Water Line. Most water from wells in the study area plot slightly above the Global Meteoric Water Line, along a local meteoric water line. Water plotting to the right of the meteoric water line may have experienced some degree of evaporation before recharging the aquifer.

NWISWeb water-quality data for each multiple-well monitoring site can be accessed through the respective web address hyperlinks in table 17. Following publication, any updates to data presented in this report will be made to the USGS NWIS database. Additional geophysical logs, sample collection notes, and other information not contained in NWIS are kept on file at the USGS CAWSC office in San Diego, Calif. Formal requests for specific data should be directed to the USGS CAWSC office, in Sacramento, California.

\section{References Cited}

Anderson, M.L., Roberts, C.W., and Jachens, R.C., 2000, Principal facts for gravity stations in the vicinity of San Bernardino, southern California: U.S. Geological Survey Open-File Report 00-193, p. 23, http://pubs.usgs.gov/ of $/ 2000 / 0193 /$.

Anderson, Megan, Matti, Jonathan, and Jachens, Robert, 2004, Structural model of the San Bernardino basin, California, from analysis of gravity, aeromagnetic, and seismicity data: Journal of Geophysical Research, Solid Earth, v. 109, no. 4, http://dx.doi.org/10.1029/2003JB002544.

Beck, A.E., 1976, The use of thermal resistivity logs in stratigraphic correlation: Geophysics, v. 41, no. 2, p. 300-309. 
Beukens, R.P., 1992, Radiocarbon accelerator mass spectrometry-Background, precision and accuracy, in Taylor, R.E., Long, A., and Kra, R.S., eds., Radiocarbon after four decades-An interdisciplinary perspective: New York, Springer-Verlag, p. 230-239.

California Department of Water Resources, 2003, California's groundwater-Upper Santa Ana Valley groundwater basin, Rialto-Colton subbasin: California Department of Water Resources Bulletin 118-Update 2003, http:// www.water.ca.gov/pubs/groundwater/bulletin_118/ basindescriptions/8-2.04.pdf.

Connor, B.F., Rose, D.L., Noriega, M.C., Murtaugh, L.K., and Abney, S.R., 1998, Methods of analysis by the U.S. Geological Survey National Water Quality Laboratory-Determination of 86 volatile organic compounds in water by gas chromatography/mass spectrometry, including detections less than reporting limits: U.S. Geological Survey OpenFile Report 97-829, 78 p.

Coplen, T.B., Wildman, J.D., and Chen, Julie, 1991, Improvements in the gaseous hydrogen-water equilibration technique for hydrogen isotope-ratio analysis: Analytical Chemistry, v. 63, no. 9, p. 910-912, http://dx.doi.org/10.1021/ ac00009a014.

Craig, Harmon, 1961, Isotopic variations in meteoric waters: Science, v. 133, no. 3465, p. 1702-1703, http://dx.doi. org/10.1126/science.133.3465.1702.

Dutcher, L.C., and Garrett, A.A., 1963, Geologic and hydrologic features of the San Bernardino area, California-With special reference to underflow across the San Jacinto Fault: U.S. Geological Survey Water-Supply Paper 1419, 114 p.

Epstein, S., and Mayeda, T., 1953, Variations of $\mathrm{O}^{18}$ content of waters from natural sources: Geochimica et Cosmochimica Acta, v. 4, no. 5, p. 213-224, http://dx.doi. org/10.1016/0016-7037(53)90051-9.

Faires, L.M., 1993, Methods of analysis by the U.S. Geological Survey National Water Quality Laboratory-Determination of metals in water by inductively coupled plasma-mass spectrometry: U.S. Geological Survey Open-File Report 92-634, 28 p.

Fishman, M.J., ed., 1993, Methods of analysis by the U.S. Geological Survey National Water Quality LaboratoryDetermination of inorganic and organic constituents in water and fluvial sediments: U.S. Geological Survey Open-File Report 93-125, 217 p., http://pubs.er.usgs.gov/ usgspubs/ofr/ofr 93125 .

Fishman, M.J., and Friedman, L.C., eds., 1989, Methods for determination of inorganic substances in water and fluvial sediments: U.S. Geological Survey Techniques of WaterResources Investigations, book 5, chap. A1, 545 p., http:// pubs.water.usgs.gov/twri5a1.
Folk, R.L., 1954, The distinction between grain size and mineral composition in sedimentary rocks: Journal of Geology, v. 62 , no. 4 , p. $344-359$.

Gleason, J.D., Friedman, I., and Hanshaw, B.B., 1969, Extraction of dissolved carbonate species from natural water for carbon-isotope analysis: U.S. Geological Survey Professional Paper 650-D, p. 248-250.

Gonfiantini, R., 1978, Standards for stable isotope measurements in natural compounds: Nature, v. 271, p. 534-536, http://dx.doi.org/10.1038/271534a0.

Ingebritsen, S.E., and Sanford, W.E., 1998, Groundwater in geologic processes: New York, N.Y., Cambridge University Press, $341 \mathrm{p}$.

Jones, S.R., and Garbarino, J.R., 1999, Methods of analysis by the U.S. Geological Survey National Water Quality Laboratory-Determination of arsenic and selenium in water and sediment by graphite furnace atomic absorption spectrometry: U.S. Geological Survey Open-File Report 98-639, 39 p.

Kent, Robert, and Landon, M.K., 2013, Trends in concentrations of nitrate and total dissolved solids in public supply wells of the Bunker Hill, Lytle, Rialto, and Colton groundwater subbasins, San Bernadino County, California-Influence of legacy land use: Science of the Total Environment, v. 452-453, p. 125-136, http://dx.doi.org/10.1016/j. scitotenv.2013.02.042.

Keys, W.S., and MacCary, L.M., 1971, Application of borehole geophysics to water-resources investigations: U.S. Geological Survey Techniques of Water-Resources Investigations, book 2, chap. E1, 126 p., http://pubs.water.usgs. gov/twri2el.

Lane, E.W., 1947, Report of the subcommittee on sediment terminology: Washington, D.C., American Geophysical Union Transactions, v. 28, no. 6, p. 936-938.

Lewis, M.E., 2006, Dissolved oxygen (ver. 2.1): U.S. Geological Survey Techniques of Water-Resources Investigations, book 9, chap. A6, sec. 6.2, June 2006, accessed March 3, 2010 from http://pubs.water.usgs.gov/twri9A6/.

McNeill, J.D., 1986, Geonics EM39 borehole conductivity meter-Theory of operation: Mississauga, Ontario, Geonics Limited, Technical Note 20, 11 p.

Michalski, Andrew, 1989, Application of temperature and electrical-conductivity logging in ground water monitoring: Groundwater Monitoring \& Remediation, v. 9, no. 3, p. 112-118, http://dx.doi.org/10.1111/j.1745-6592.1989. tb01158.x.

Munsell Color, 1994, Munsell soil color charts: Baltimore, Md., Munsell Color, Inc. 
Patton, C.J., and Truitt, E.P., 1992, Methods of analysis by the U.S. Geological Survey National Water Quality Laboratory-Determination of total phosphorus by a Kjeldahl digestion method and an automated colorimetric finish that includes dialysis: U.S. Geological Survey Open-File Report 92-146, 39 p.

Rounds, S.A., 2006, Alkalinity and acid neutralizing capacity (ver. 3.0): U.S. Geological Survey Techniques of WaterResources Investigations, book 9, chap. A6., sec. 6.6, July 2006, accessed March 3, 2010 from http://pubs.water.usgs. gov/twri9A6/.

Schlumberger, 1972, Log interpretation, volume I-Principles: New York, Schlumberger Limited, 112 p.

Struzeski, T.M., DeGiacomo, W.J., and Zayhowski, E.J., 1996, Methods of analysis by the U.S. Geological Survey National Water Quality Laboratory-Determination of dissolved aluminum and boron in water by inductively coupled plasma-atomic emission spectrometry: U.S. Geological Survey Open-File Report 96-149, 17 p.

Stuiver, M., and Polach, H.A., 1977, Discussion-Reporting of 14C data: Radiocarbon, v. 19, no. 3, p. 355-363.

Thatcher, L.L., Janzer, V.J., and Edwards, K.W., 1977, Methods for determination of radioactive substances in water and fluvial sediments: U.S. Geological Survey Techniques of Water-Resources, book 5, chap. A5, 95 p., http://pubs.water. usgs.gov/twri5a5.

U.S. Geological Survey, 2006, Collection of water samples (ver. 2.0): U.S. Geological Survey Techniques of WaterResources Investigations, book 9, chap. A4, September 2006, accessed March 3, 2010, at http://pubs.water.usgs. gov/twri9A4/.

Wilde, F.D., ed., 2004, Cleaning of equipment for water sampling (ver. 2.0): U.S. Geological Survey Techniques of Water-Resources Investigations, book 9, chap. A3, April 2004, accessed March 3, 2010, at http://pubs.water.usgs. gov/twri9A3/.

Wilde, F.D., Radtke, D.B., Gibs, Jacob, and Iwatsubo, R.T., eds., 2004 with updates through 2009, Processing of water samples (ver. 2.2): U.S. Geological Survey Techniques of Water-Resources Investigations, book 9, chap. A5, April 2004, accessed March 3, 2010, at http://pubs.water.usgs. gov/twri9A5/.

Williams, C.F., Galanis, S.P., Jr., Grubb, F.V., and Moses, T.H., Jr., Filippelli, G.M., Delaney, M.L., 1994, The thermal regime of Santa Maria Province, California-Phosphorus geochemistry, diagenesis, and mass balances of the Miocene Monterey Formation at Shell Beach, California: U.S. Geological Survey Bulletin 1995-F,G, 26 p.
Woolfenden, L.R., and Kadhim, Dina, 1997, Geohydrology and water chemistry in the Rialto-Colton Basin, San Bernardino County, California: U.S. Geological Survey WaterResources Investigations Report 97-4012, 101 p. 


\section{Figures}




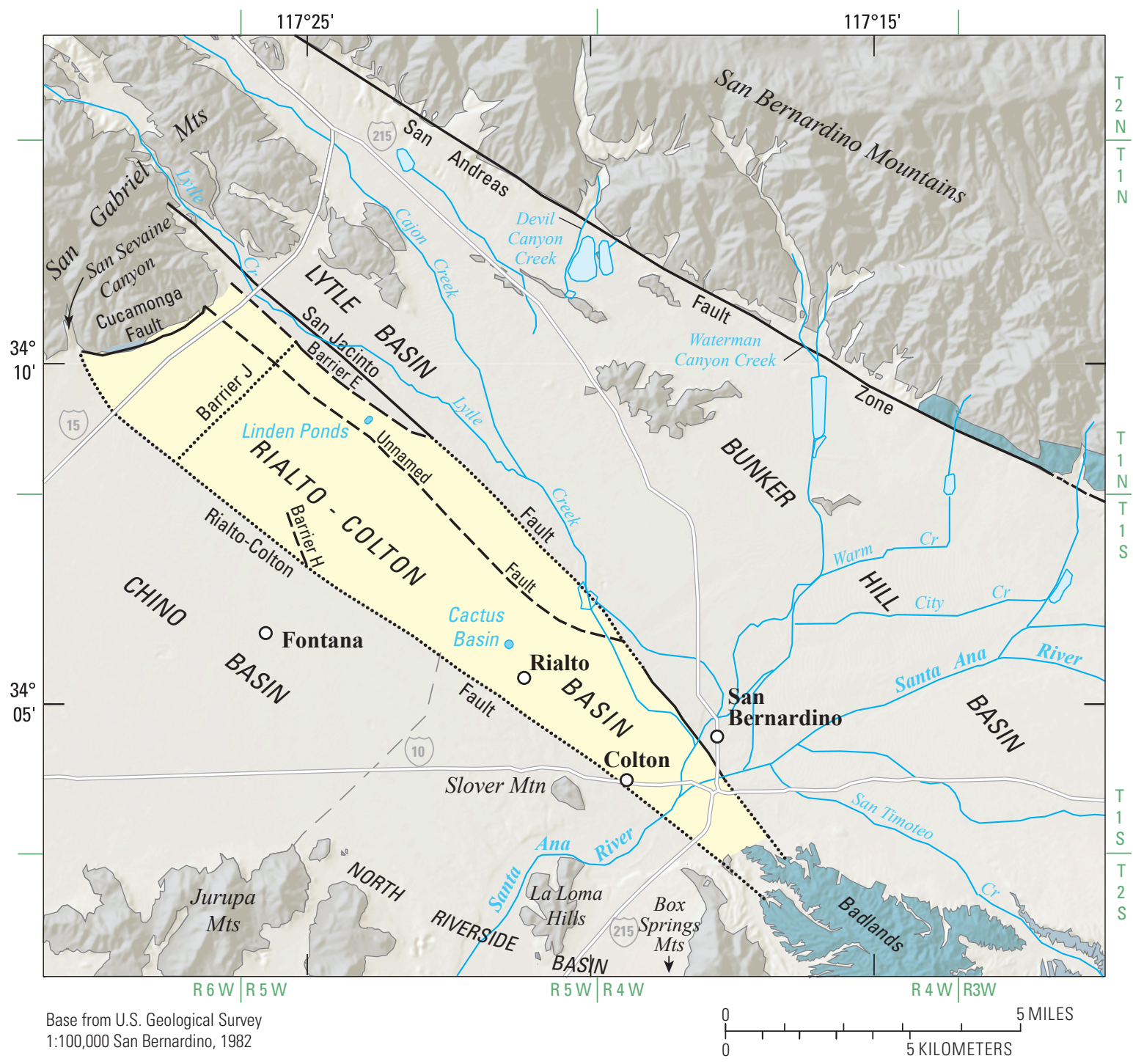

EXPLANATION
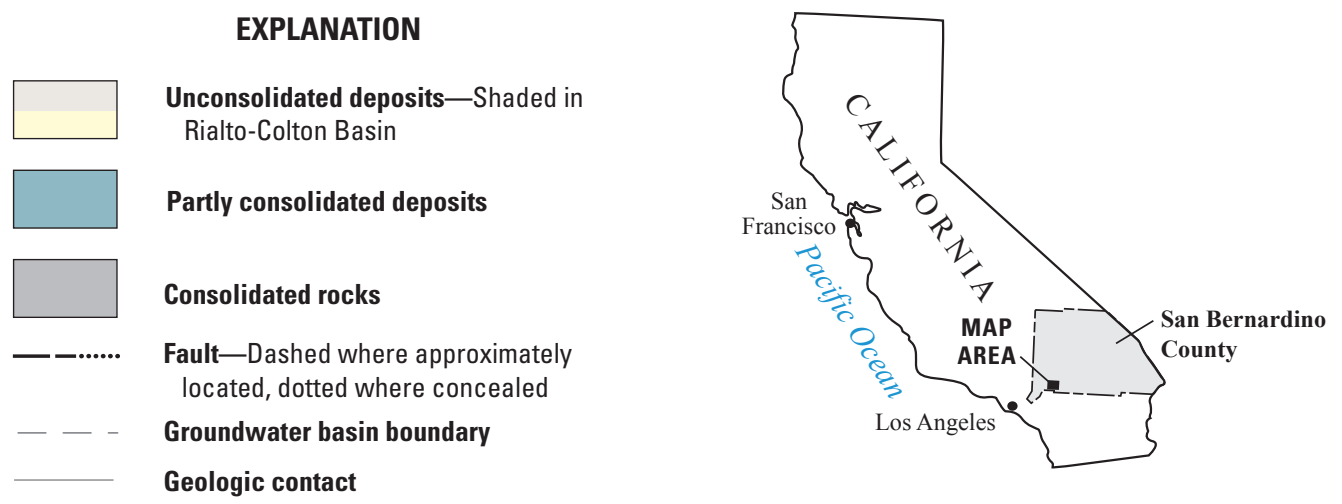

Figure 1. Location of study area and geologic and other features, San Bernardino County, California. 


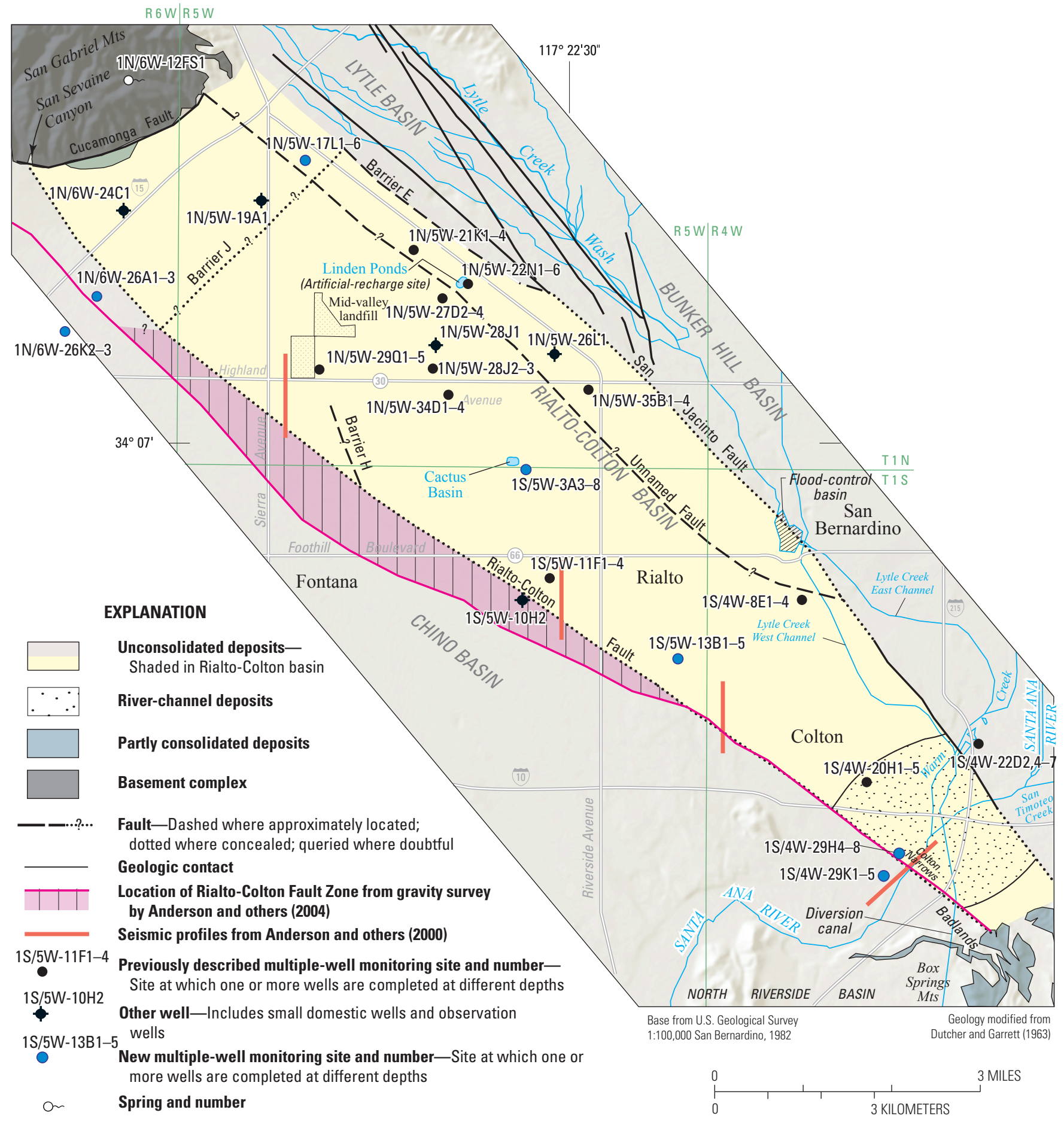

Figure 2. Locations of multiple-well monitoring sites, San Bernardino County, California. 


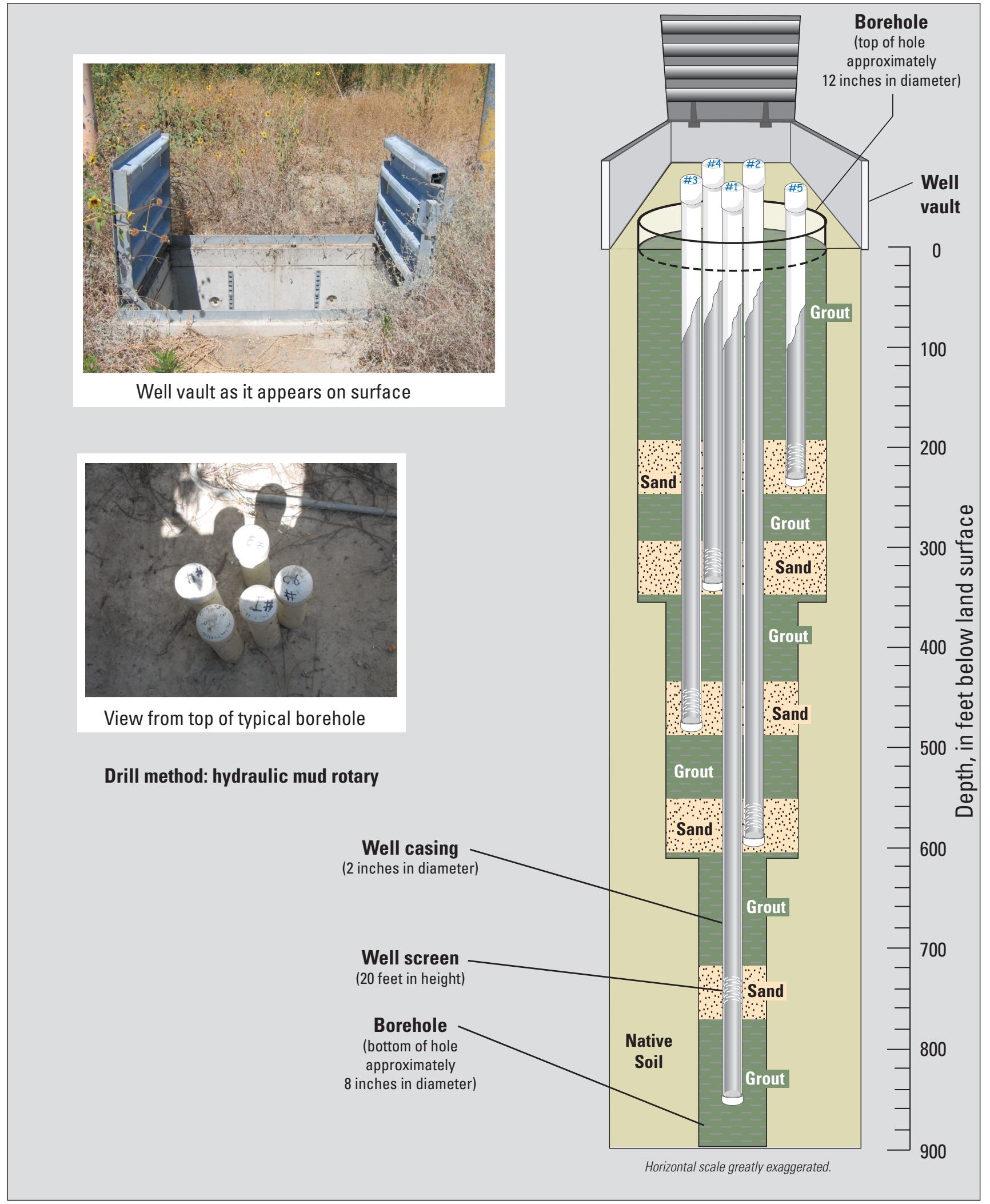

Figure 3. Typical multiple-well monitoring site completion and construction. 


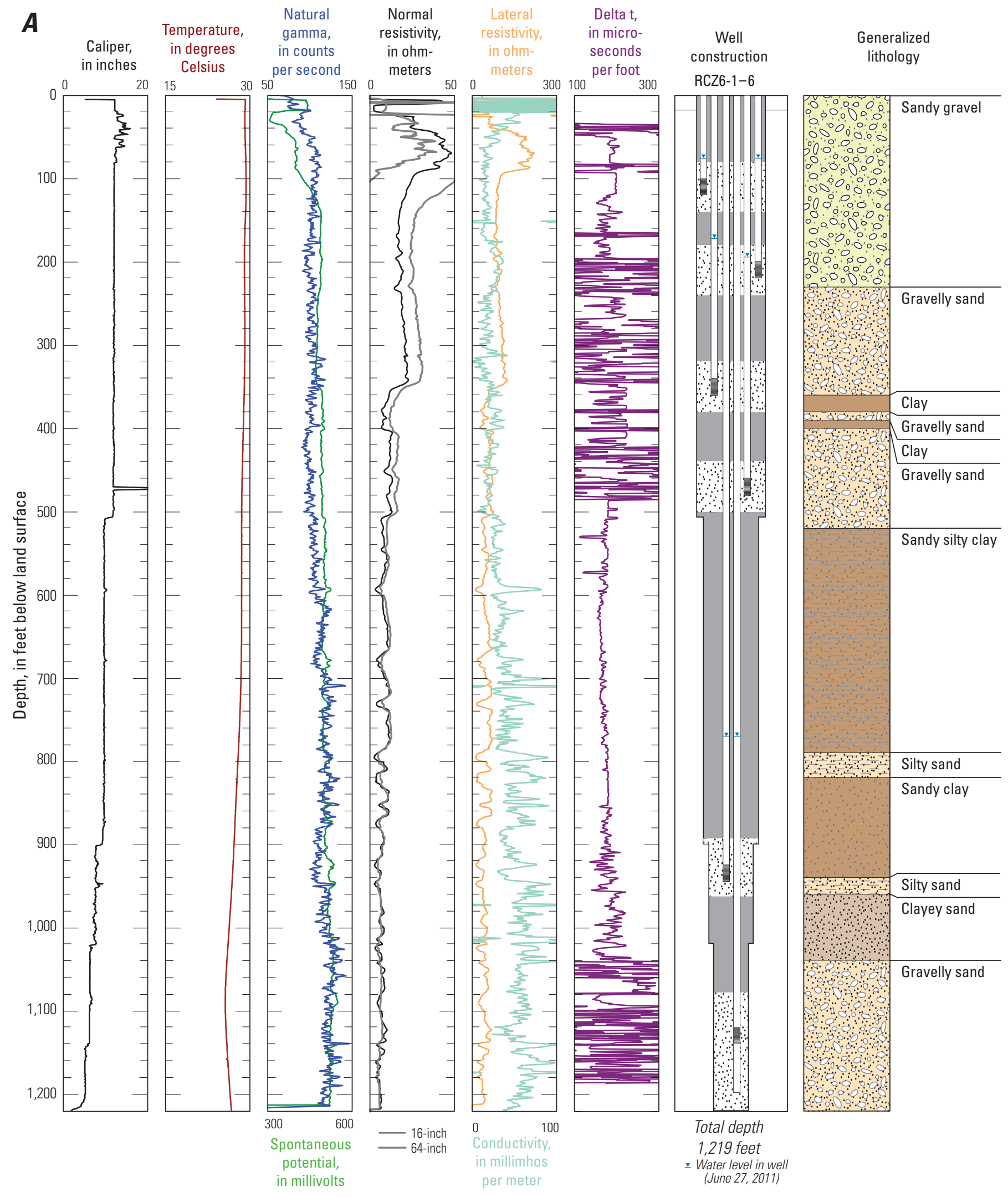

Figure 4. Geophysical logs, well-construction diagrams, and generalized lithologic descriptions for multiple-well monitoring sites, San Bernardino County, Calif.; $A$, RCZ6 (1N/5W-17L1-6); $B, \operatorname{RCNE}(1 \mathrm{~N} / 6 \mathrm{~W}-26 \mathrm{~A} 1-3) ; C$, RCSW (1N/6W-26K2-3); $D, \mathrm{CRCR}(1 \mathrm{~S} / 5 \mathrm{~W}-03 \mathrm{A3}-8)$; $E$, RHSW (1S/5W-13B1-5); F, FOG1 (1S/4W-29H4-8); G, FOG2 (1S/4W-29K1-5). 
Figures

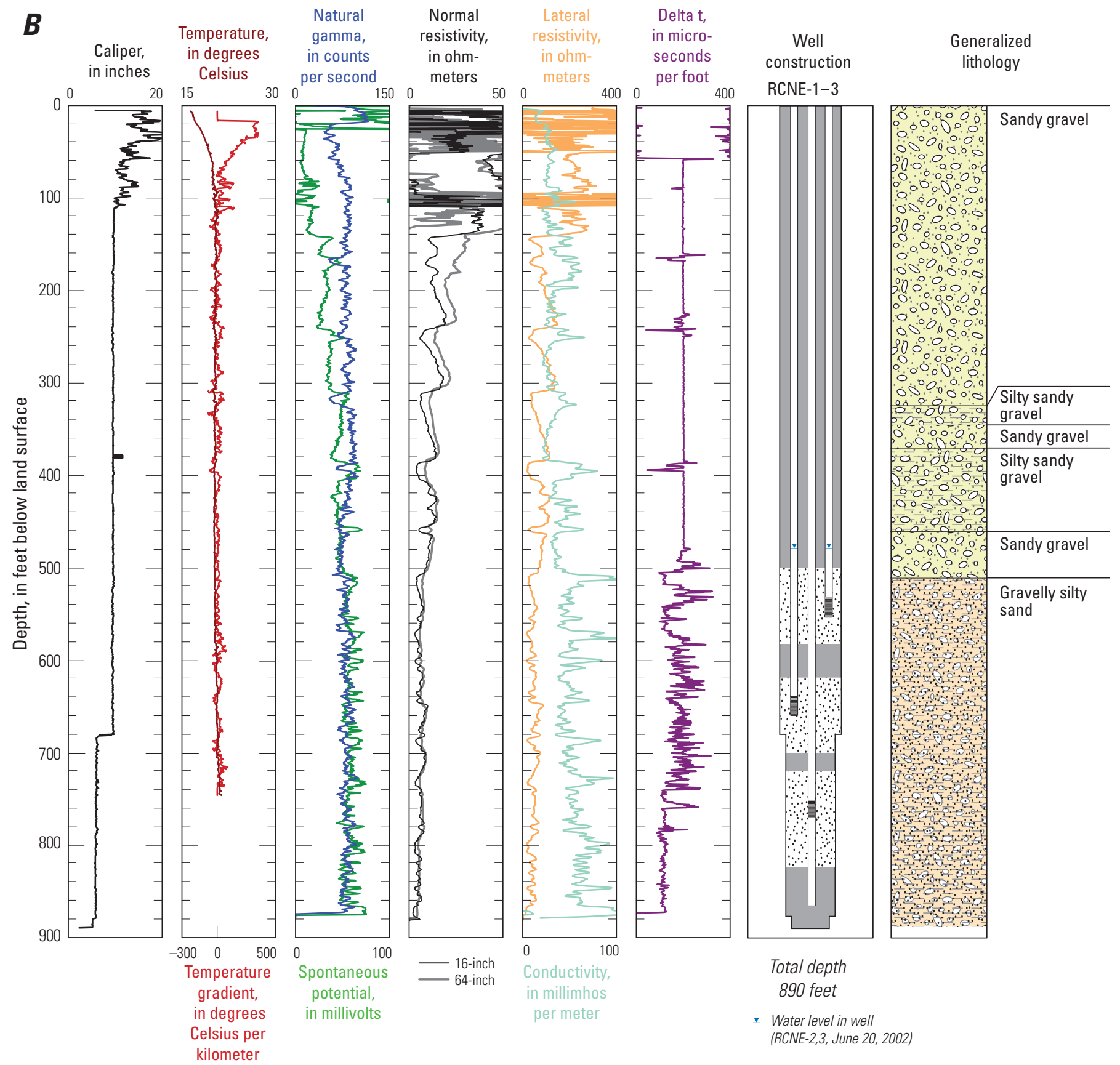

Figure 4. - Continued 


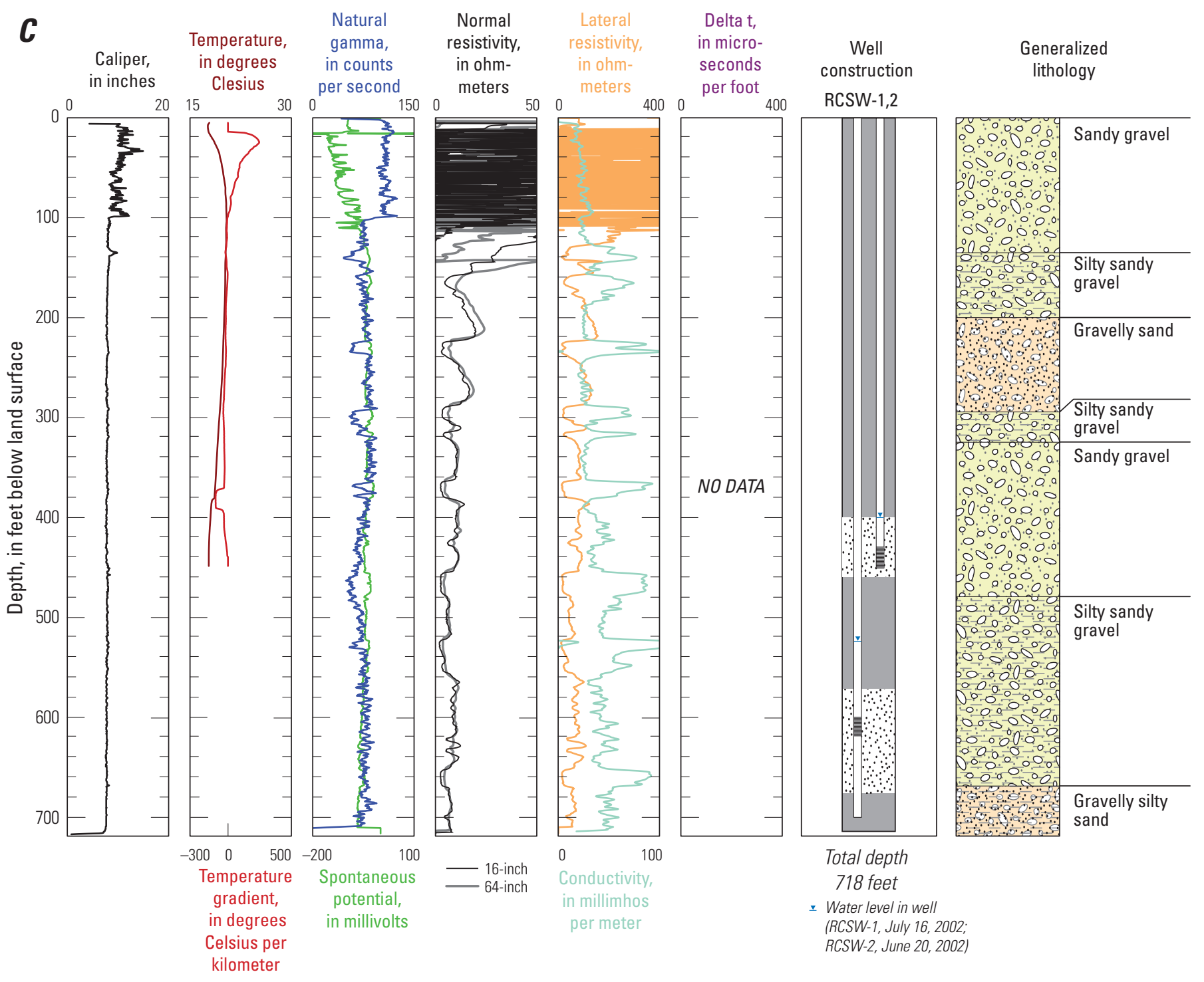

Figure 4. - Continued 
Figures

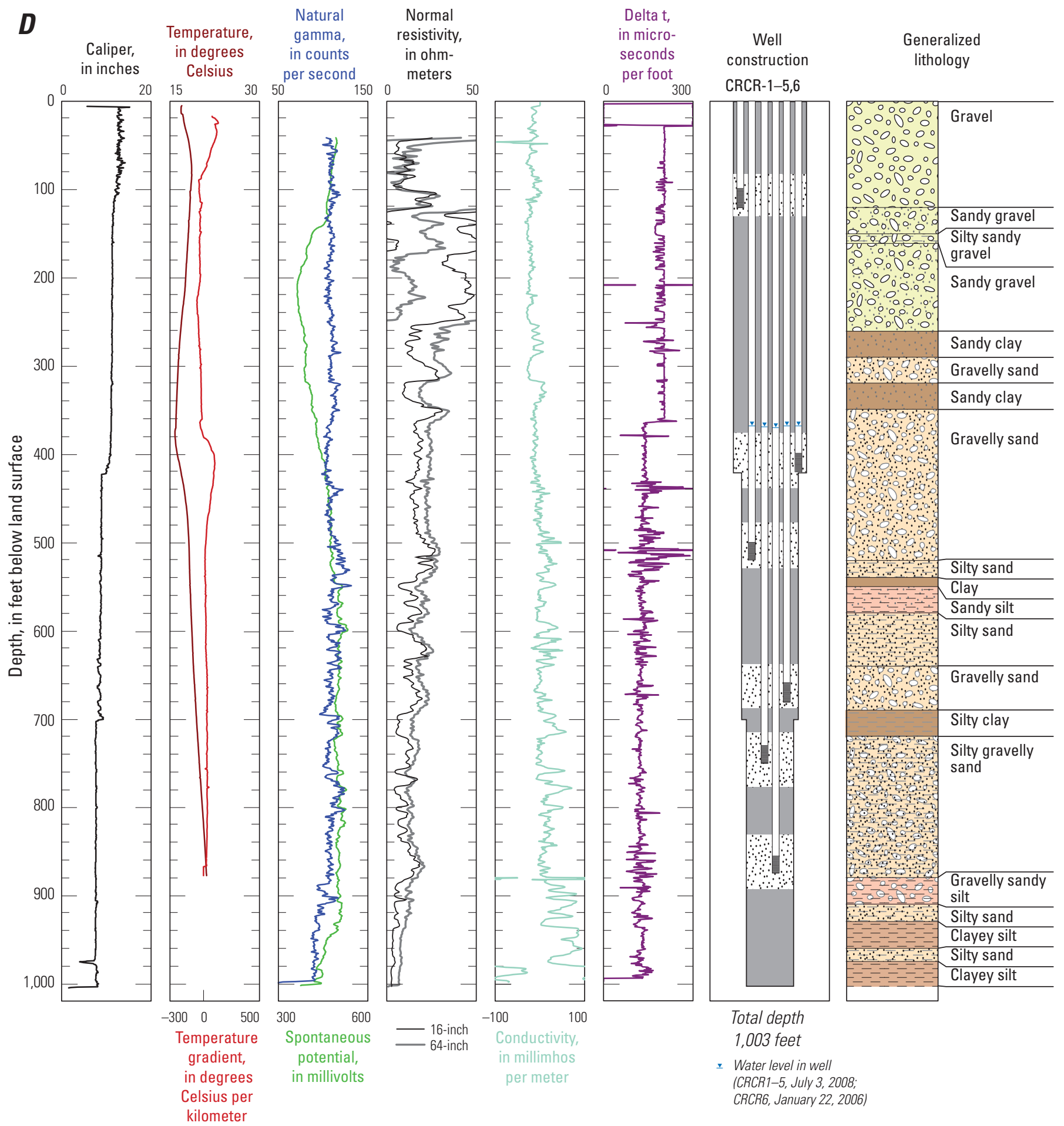

Figure 4. - Continued 


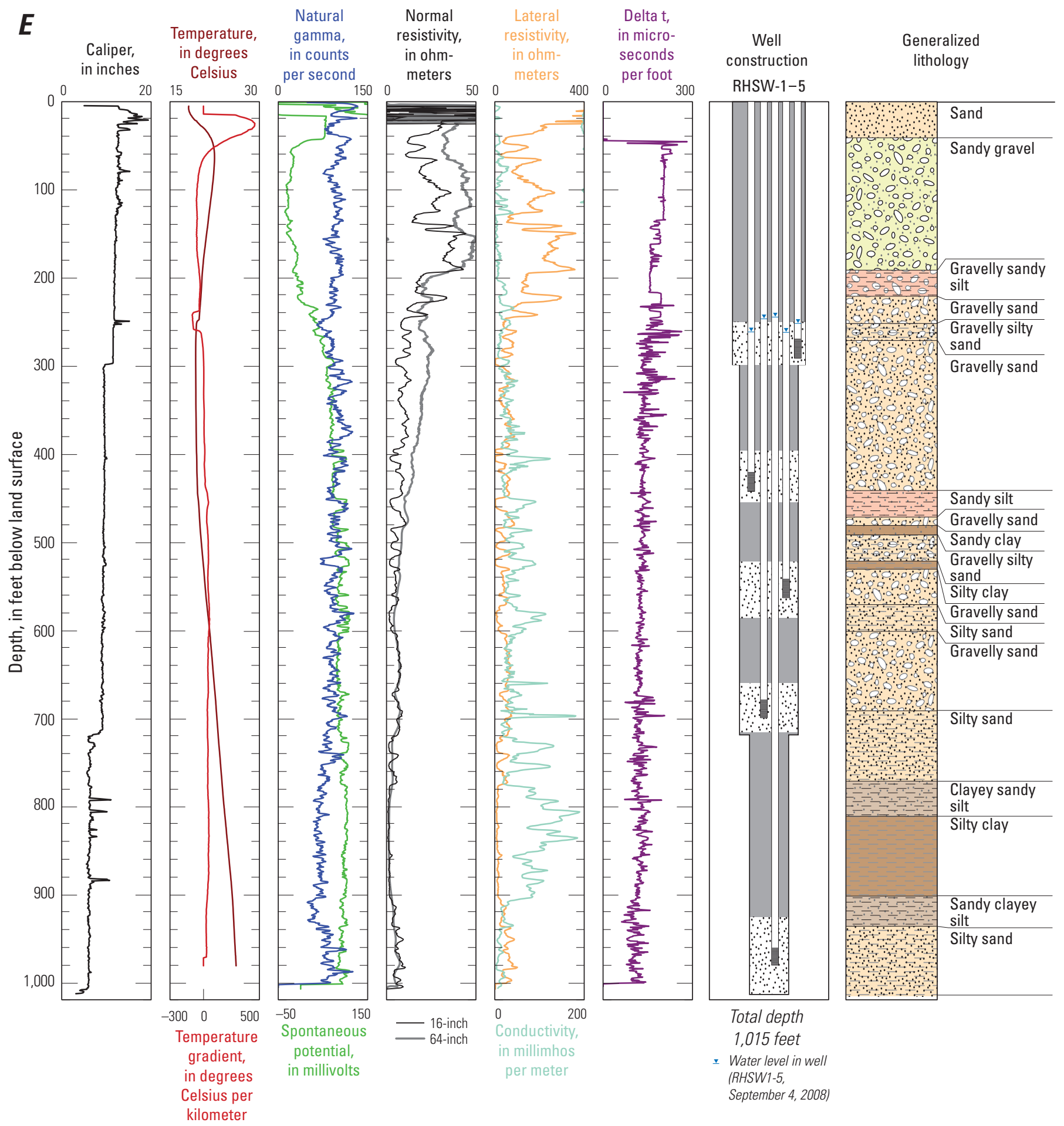

Figure 4. - Continued 
Figures
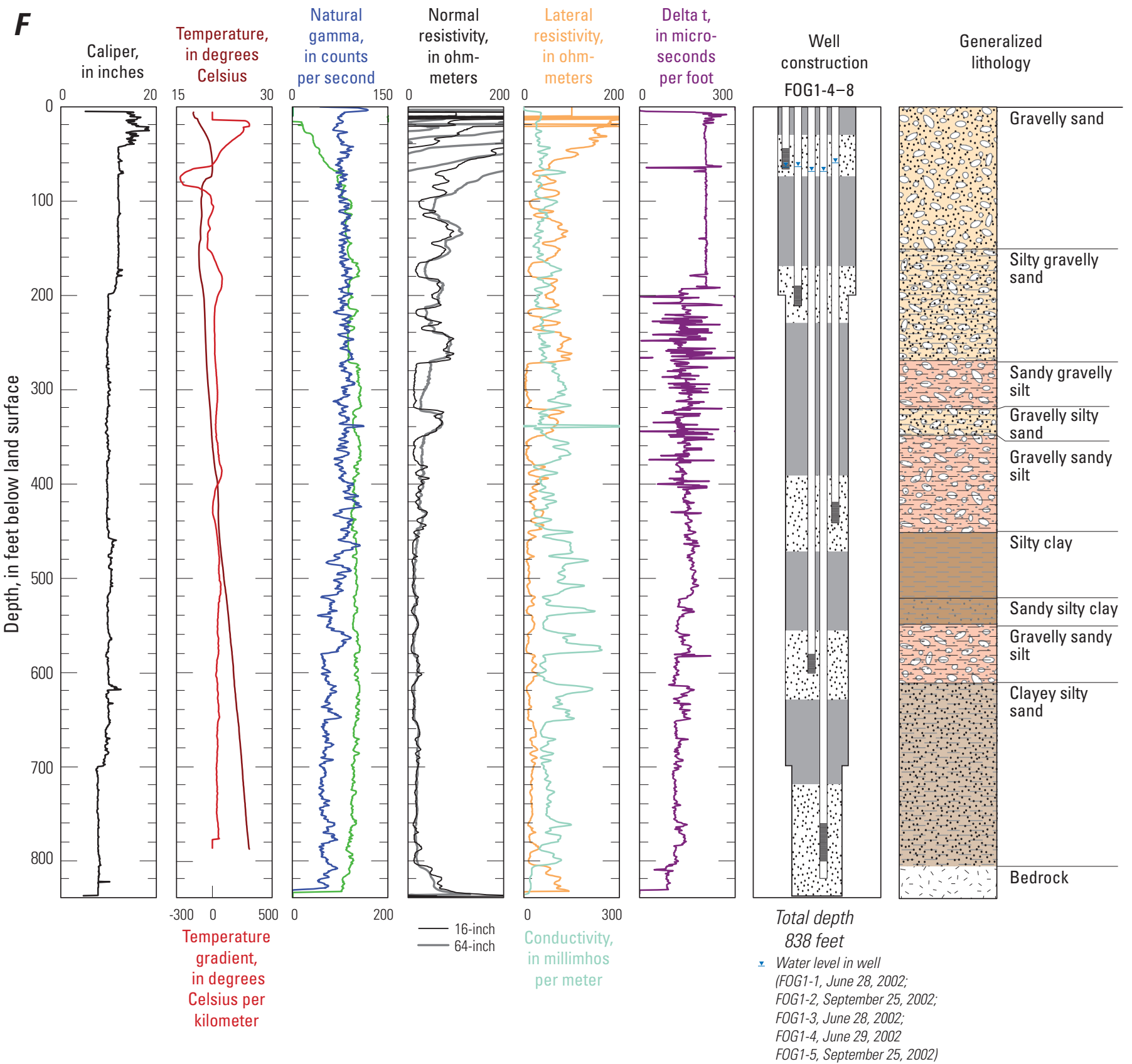

Figure 4. - Continued 


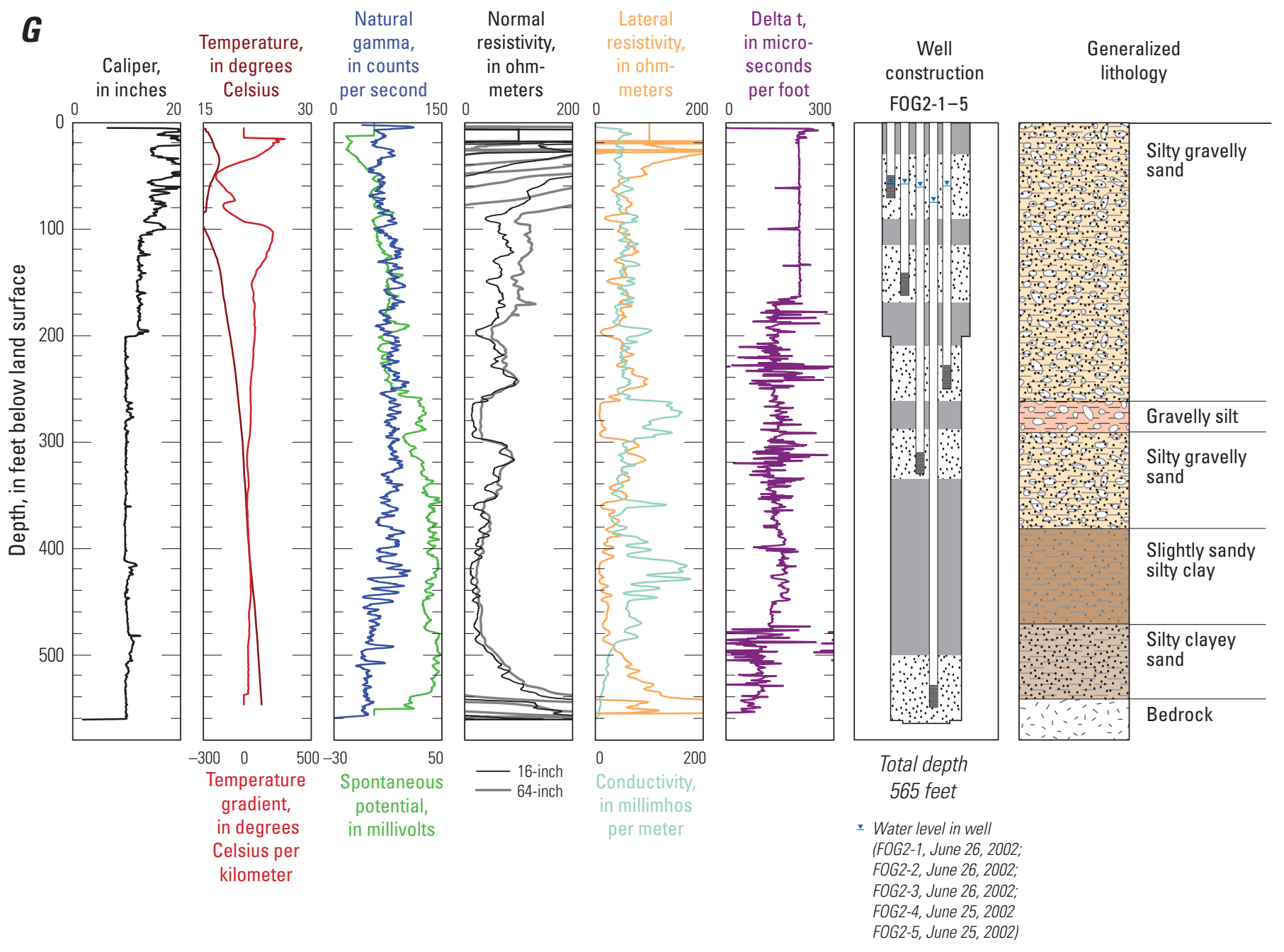

Figure 4. - Continued 

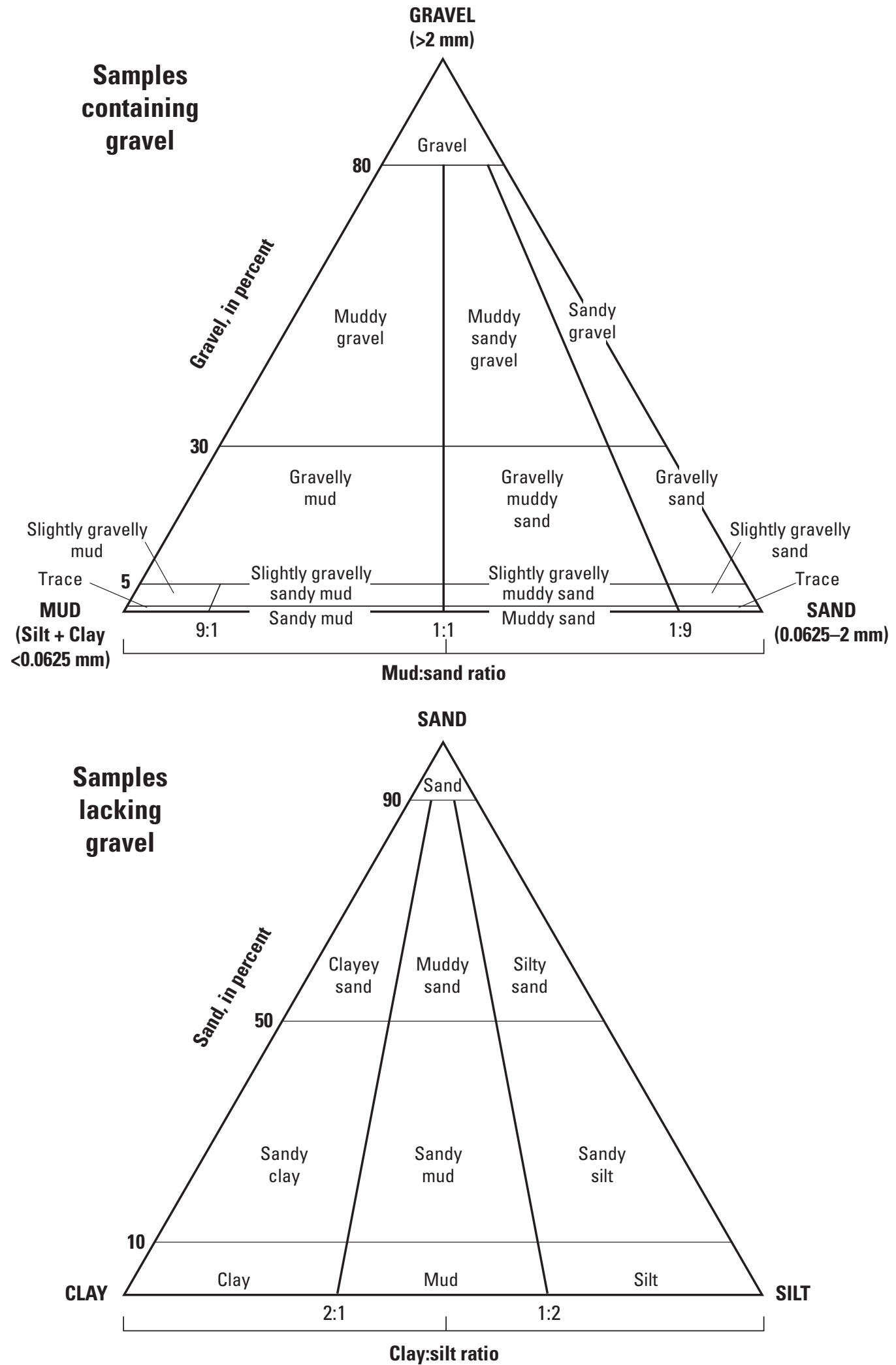

$>$, greater than; <, less than; mm, millimeters

Modified from Lane, 1947

Figure 5. Grain-size classification chart. 


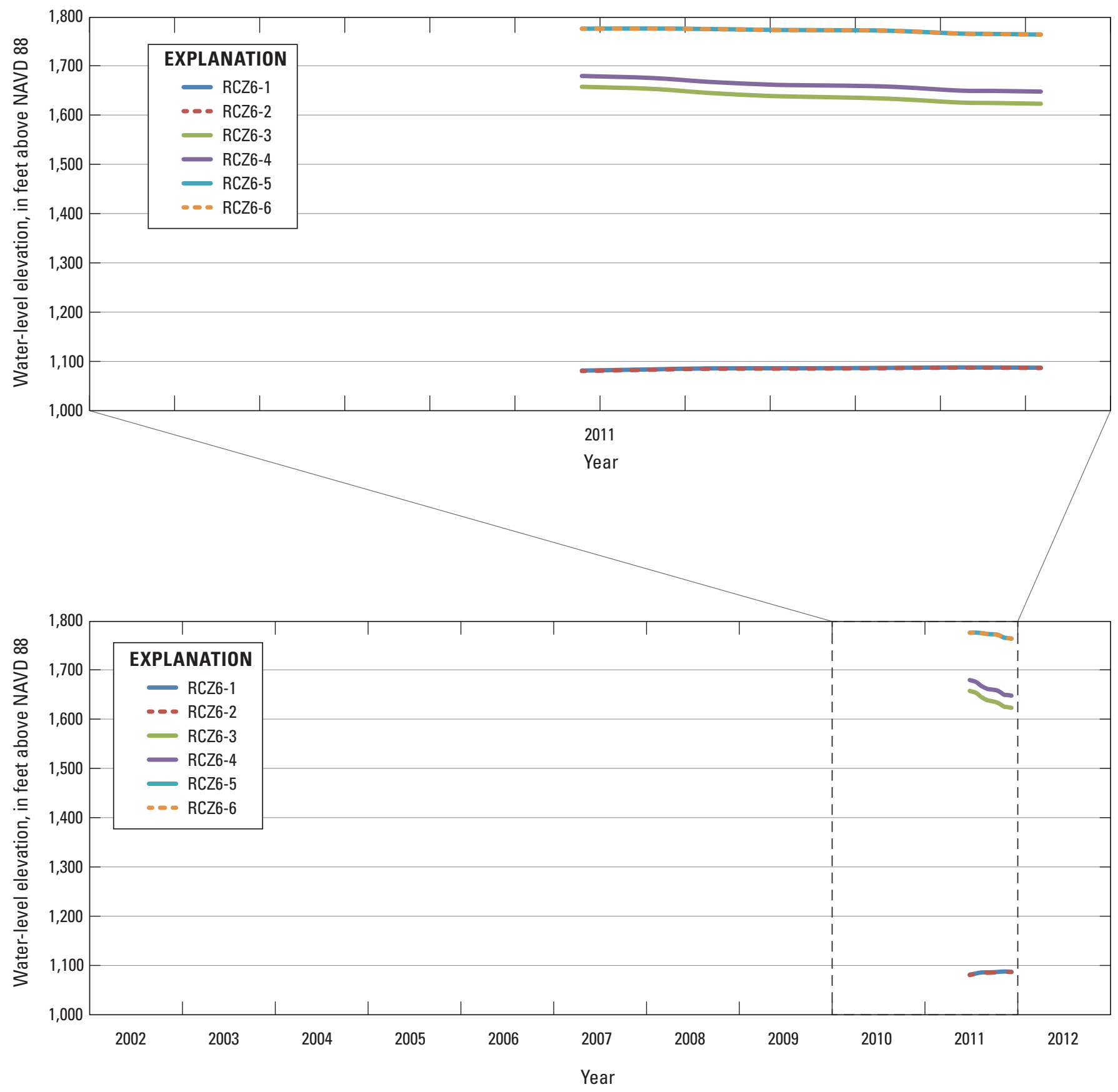

Figure 6. Water-level elevation in multiple-well monitoring site RCZ6 (1N/5W-17L1-6), San Bernardino County, California. 


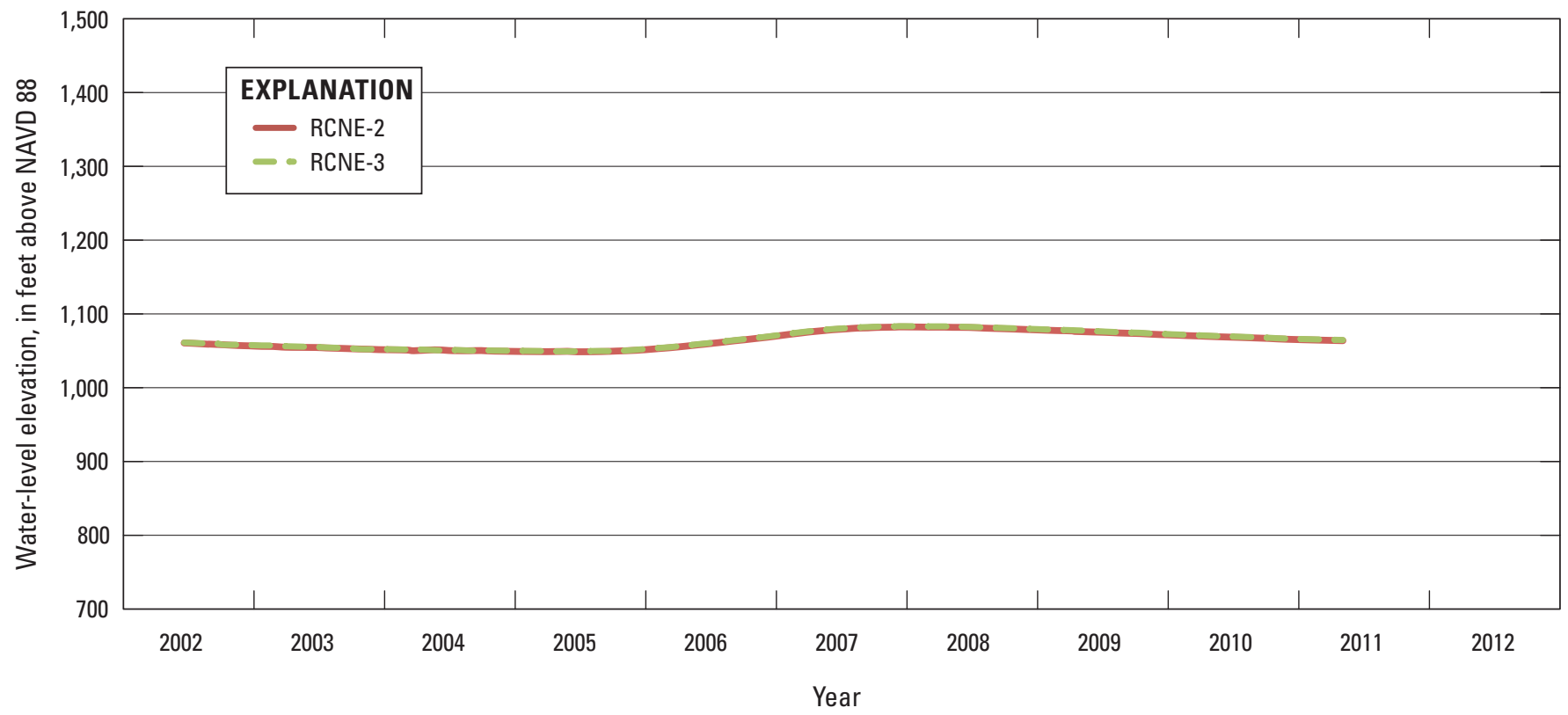

Figure 7. Water-level elevation in multiple-well monitoring site $R C N E(1 N / 6 W-26 A 2-3)$, San Bernardino County, California.

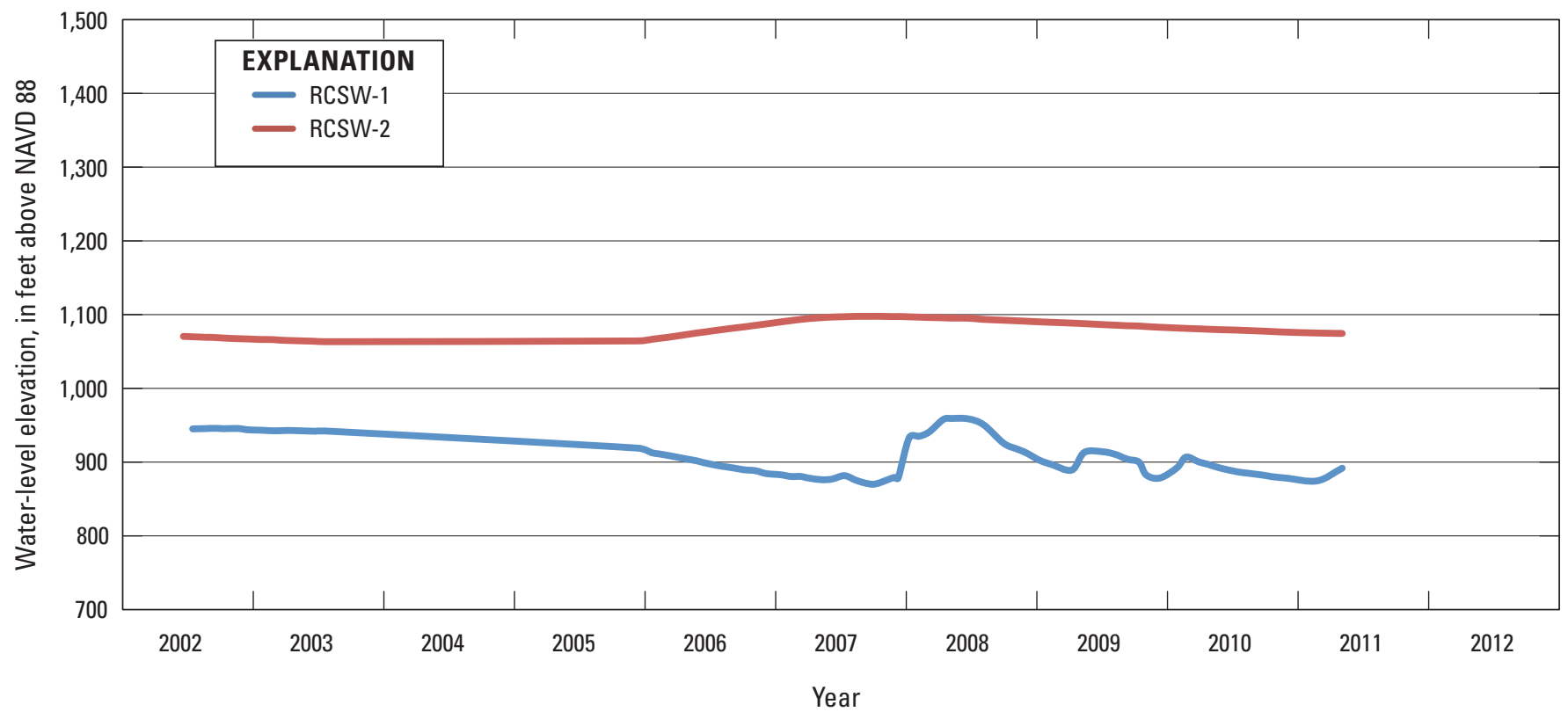

Figure 8. Water-level elevation in multiple-well monitoring site $R C S W(1 N / 6 W-26 K 2-3)$, San Bernardino County, California. 


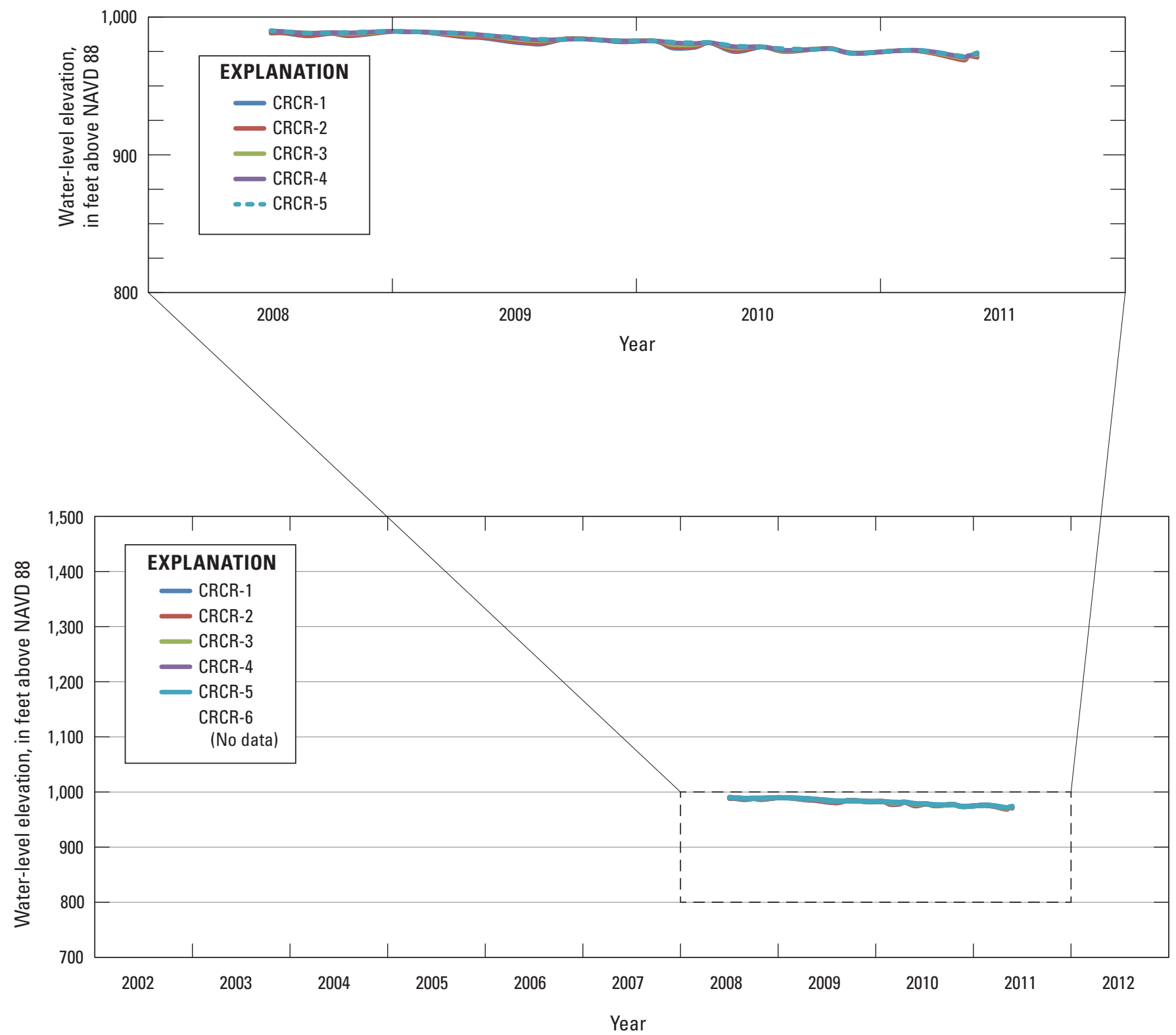

Figure 9. Water-level elevation in multiple-well monitoring site $C R C R(1 S / 5 W-03 A 3-8)$, San Bernardino County, California. 


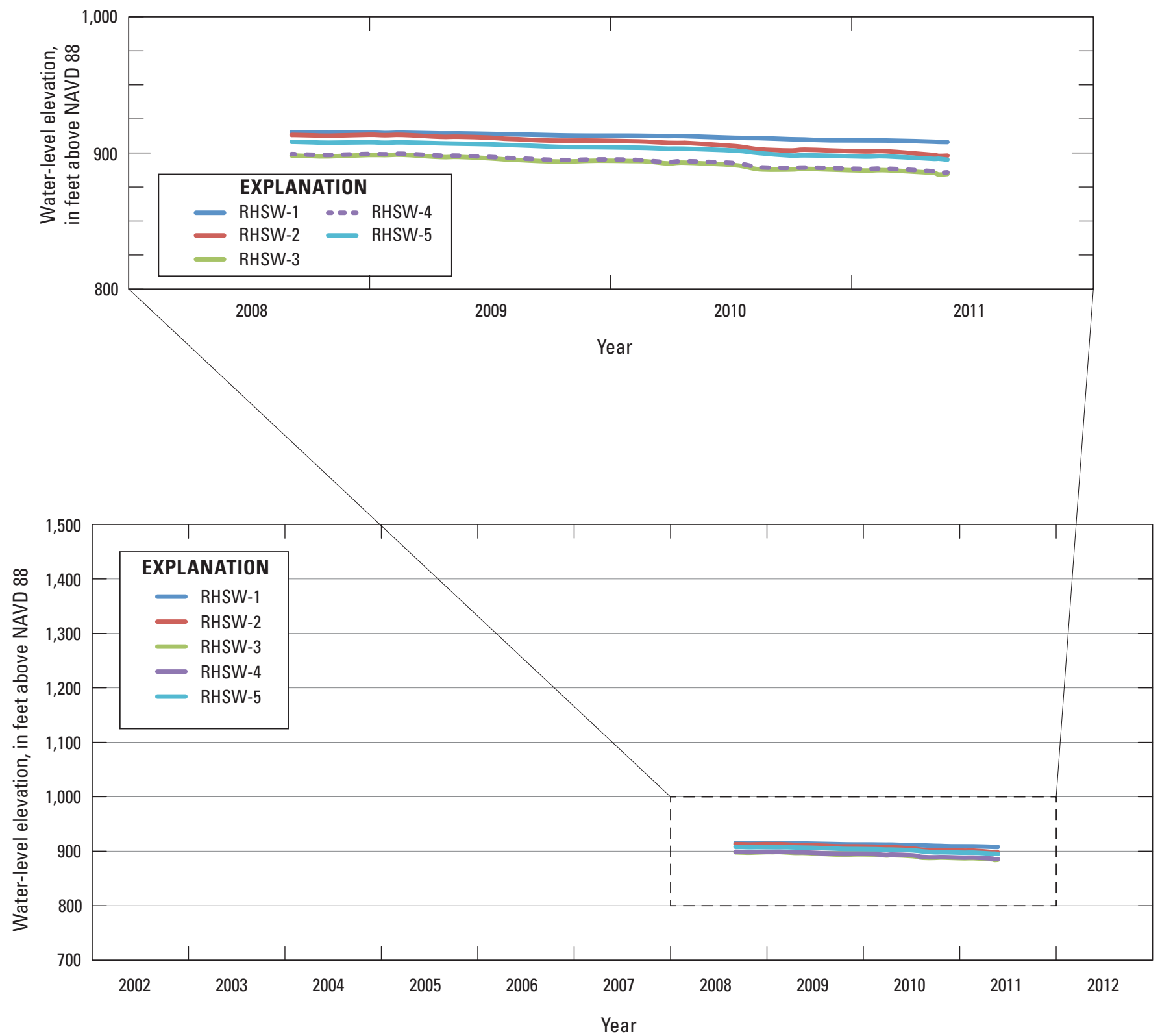

Figure 10. Water-level elevation in multiple-well monitoring site RHSW (1S/5W-13B1-5), San Bernardino County, California. 


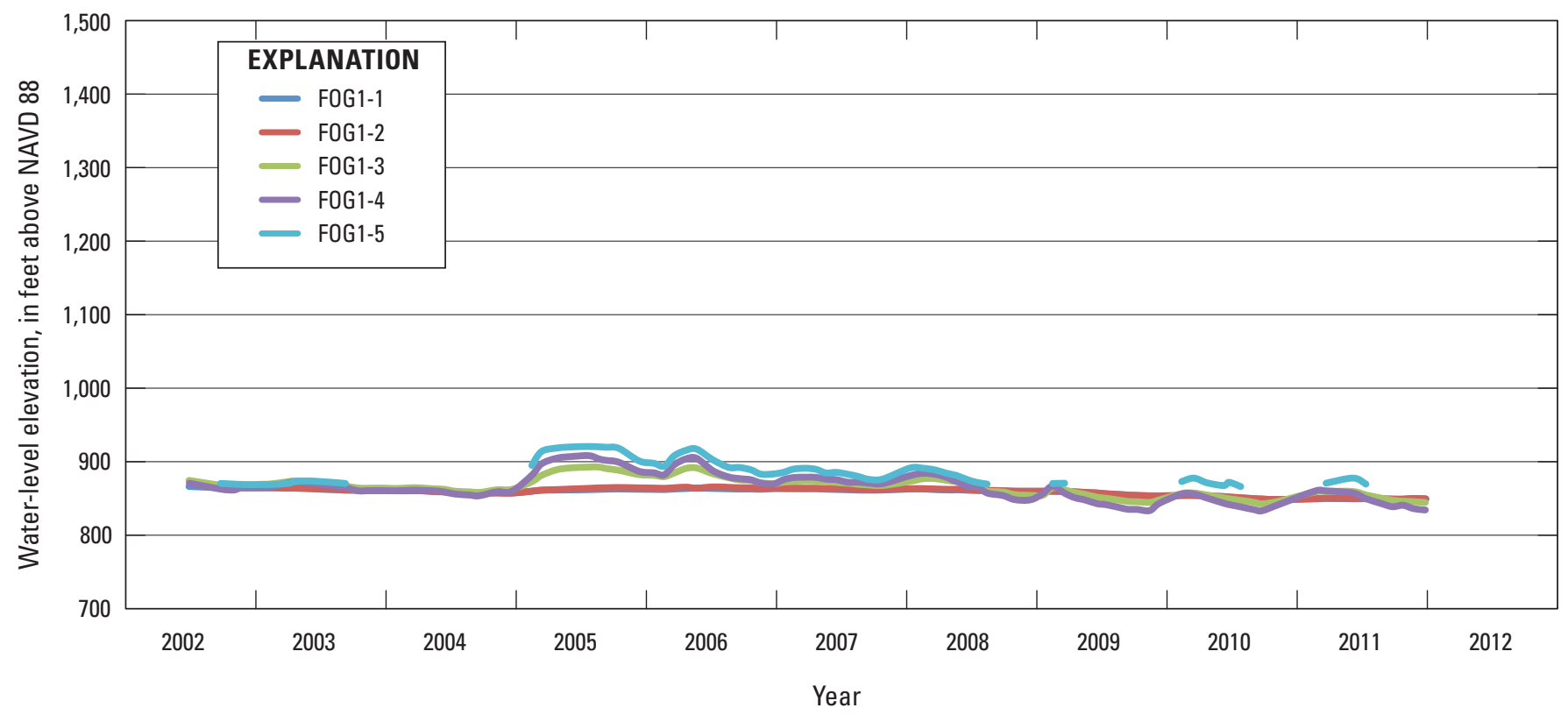

Figure 11. Water-level elevation in multiple-well monitoring site FOG1 (1S/4W-29H4-8), San Bernardino County, California.

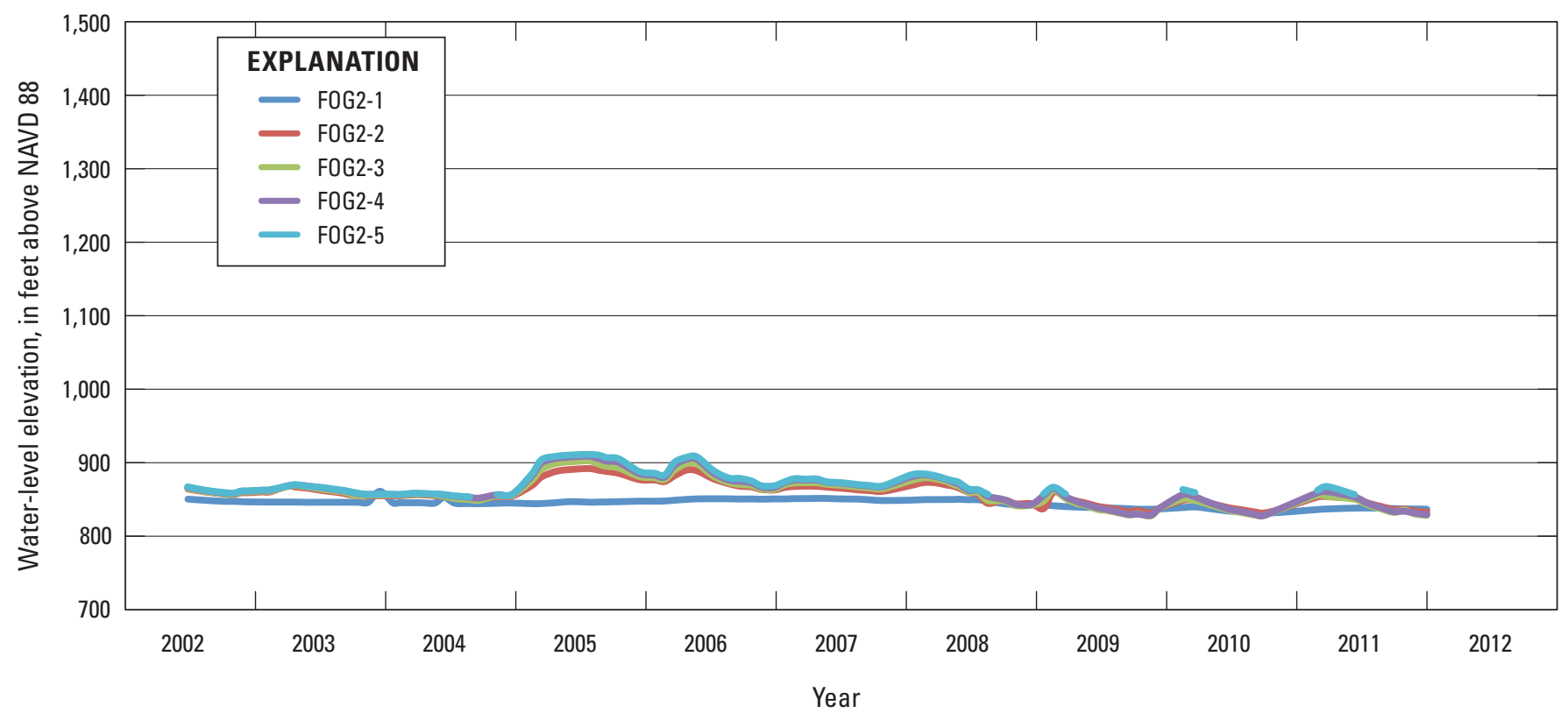

Figure 12. Water-level elevation in multiple-well monitoring site FOG2 (1S/4W-29K1-5), San Bernardino County, California. 


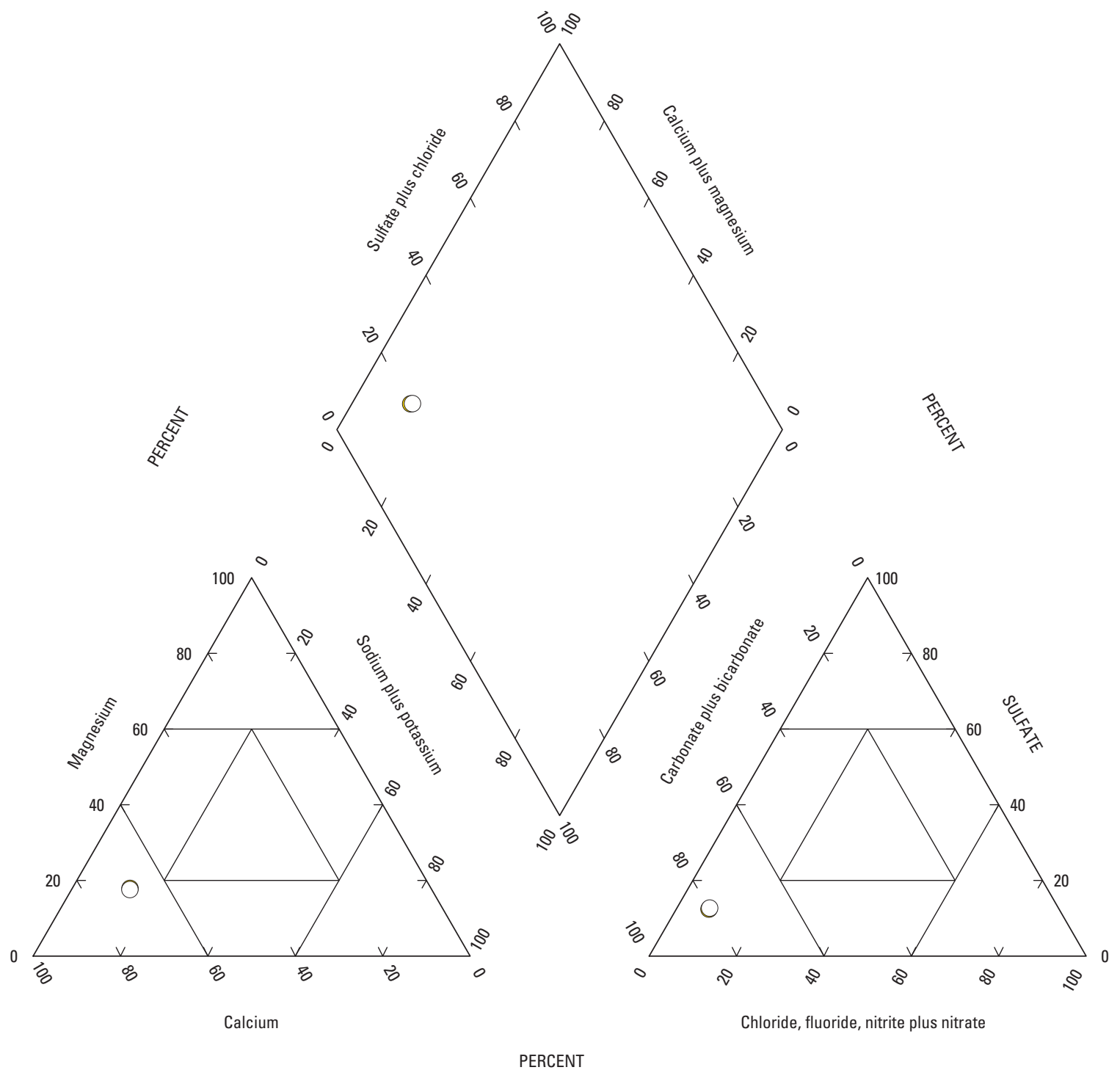

EXPLANATION

Site and well number

RCZ6-6

RCZ6-5

Figure 13. Major-ion chemistry of water from multiple-well monitoring site RCZ6 (1N/5W-17L1-6), San Bernardino County, California, 2011. 


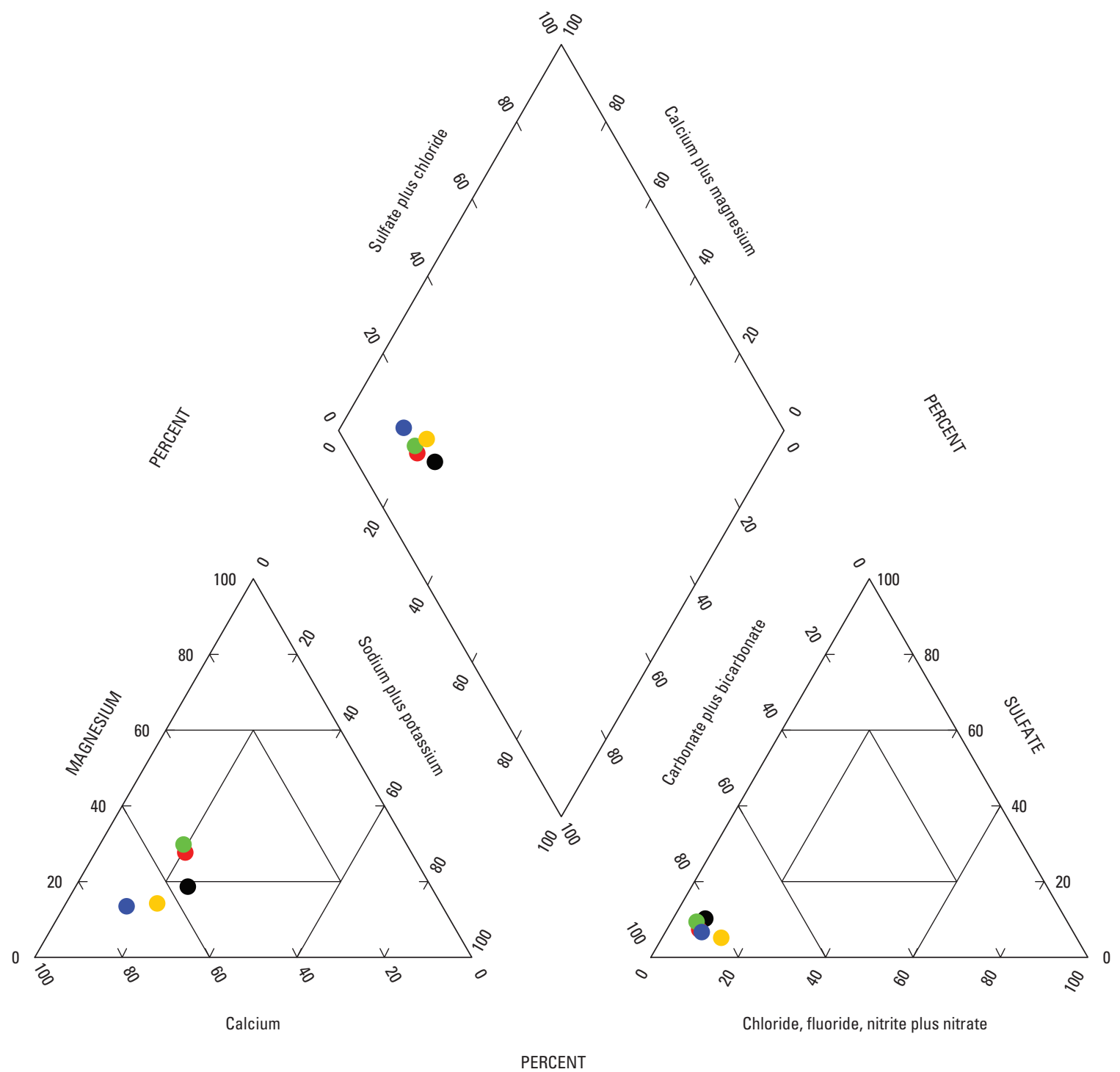

\section{EXPLANATION}

Site and well number

- CRCR-5

- CRCR-4

- CRCR-3

- CRCR-2

- CRCR-1

Figure 14. Major-ion chemistry of water from multiple-well monitoring site CRCR (1S/5W-03A3-8), San Bernardino County, California, 2007. 


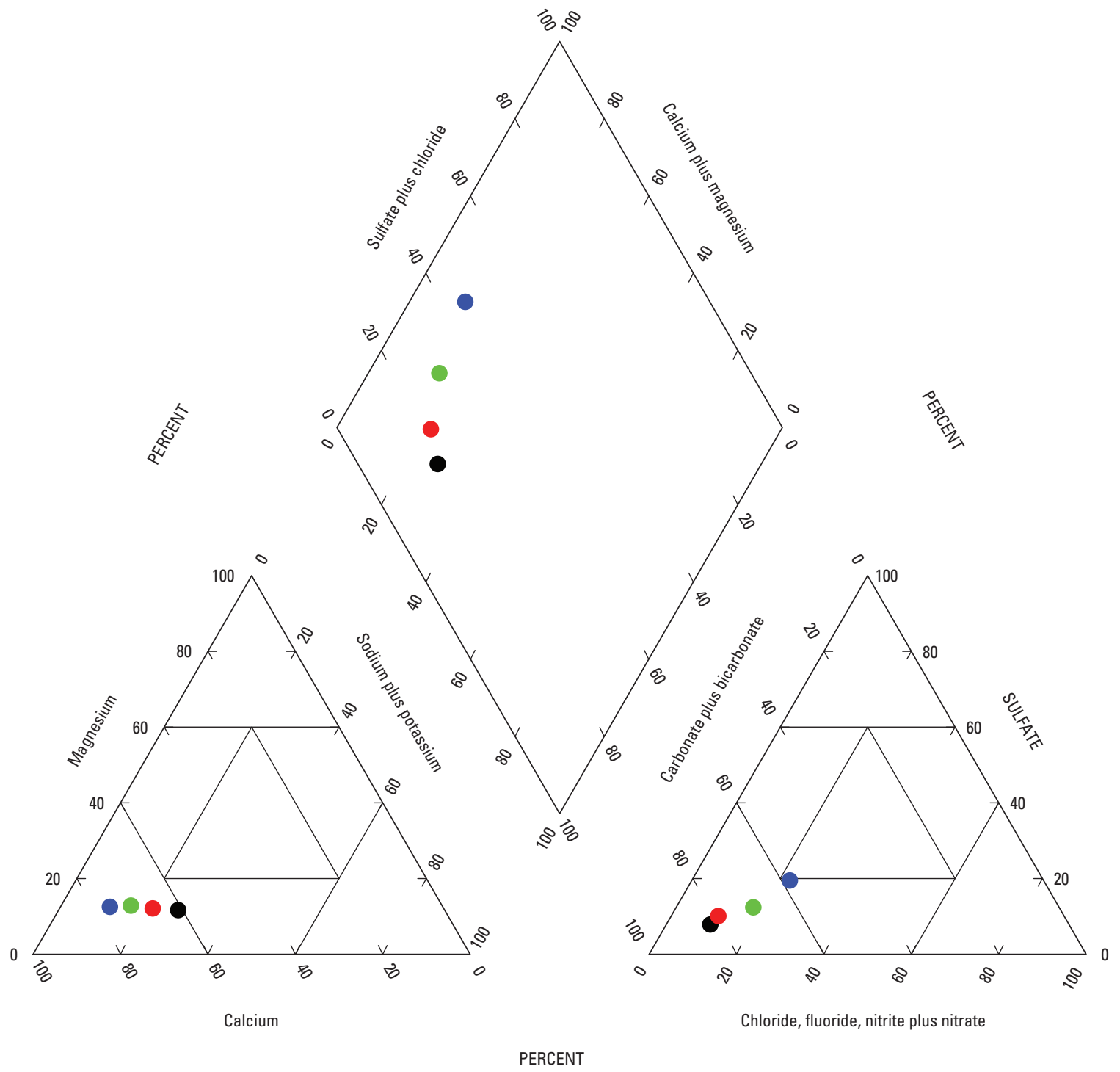

EXPLANATION

Site and well number

- RHSW-5

- RHSW-4

RHSW-3

RHSW-2

Figure 15. Major-ion chemistry of water from multiple-well monitoring site RHSW (1S/5W-13B1-5), San Bernardino County, California, 2007. 


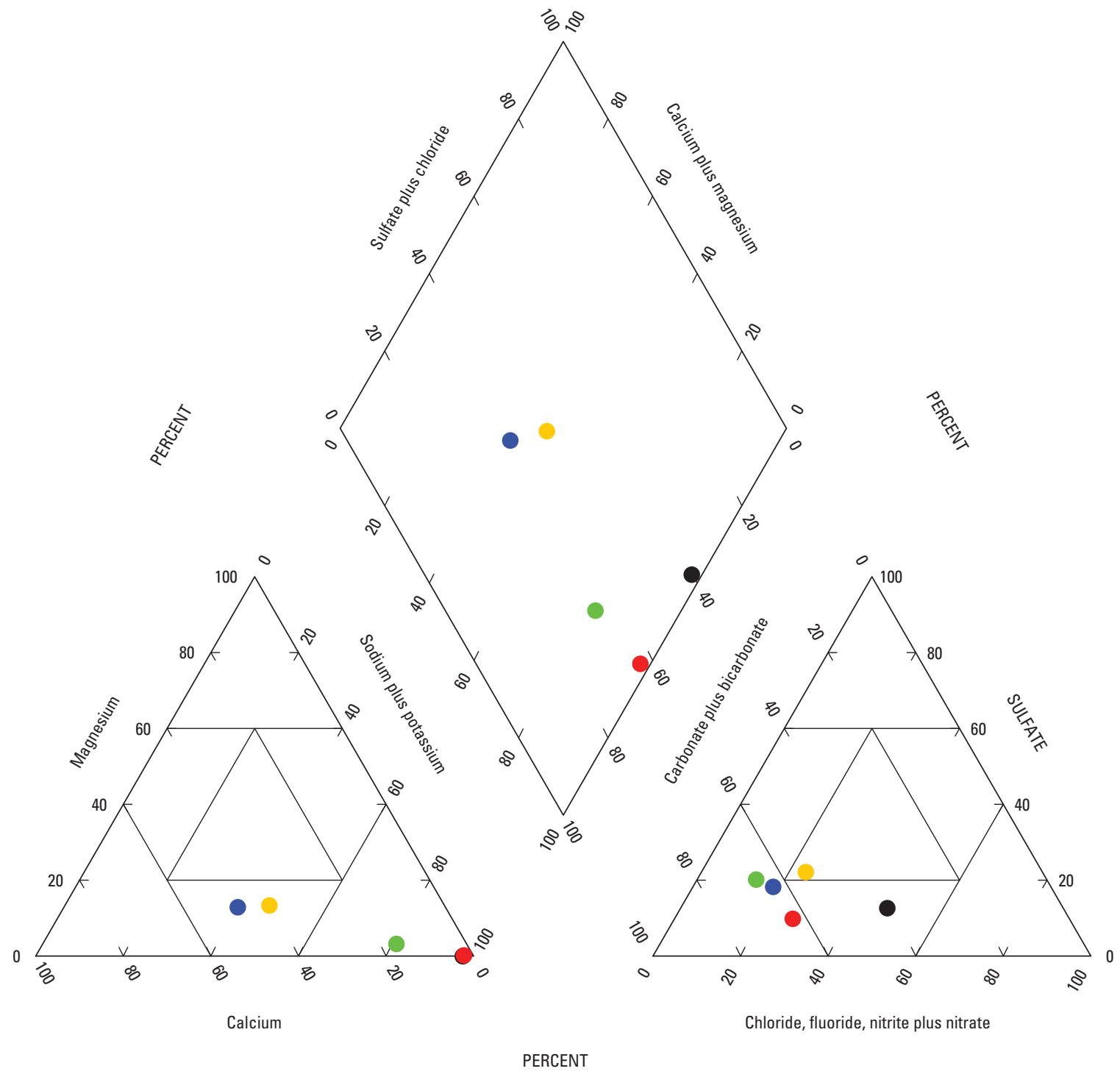

\section{EXPLANATION}

Site and well number

FOG1-5

- FOG1-4

FOG1-3

FOG1-2

- FOG1-1

Figure 16. Major-ion chemistry of water from multiple-well monitoring site F0G1 (1S/4W-29H4-8), San Bernardino County, California, 2007. 


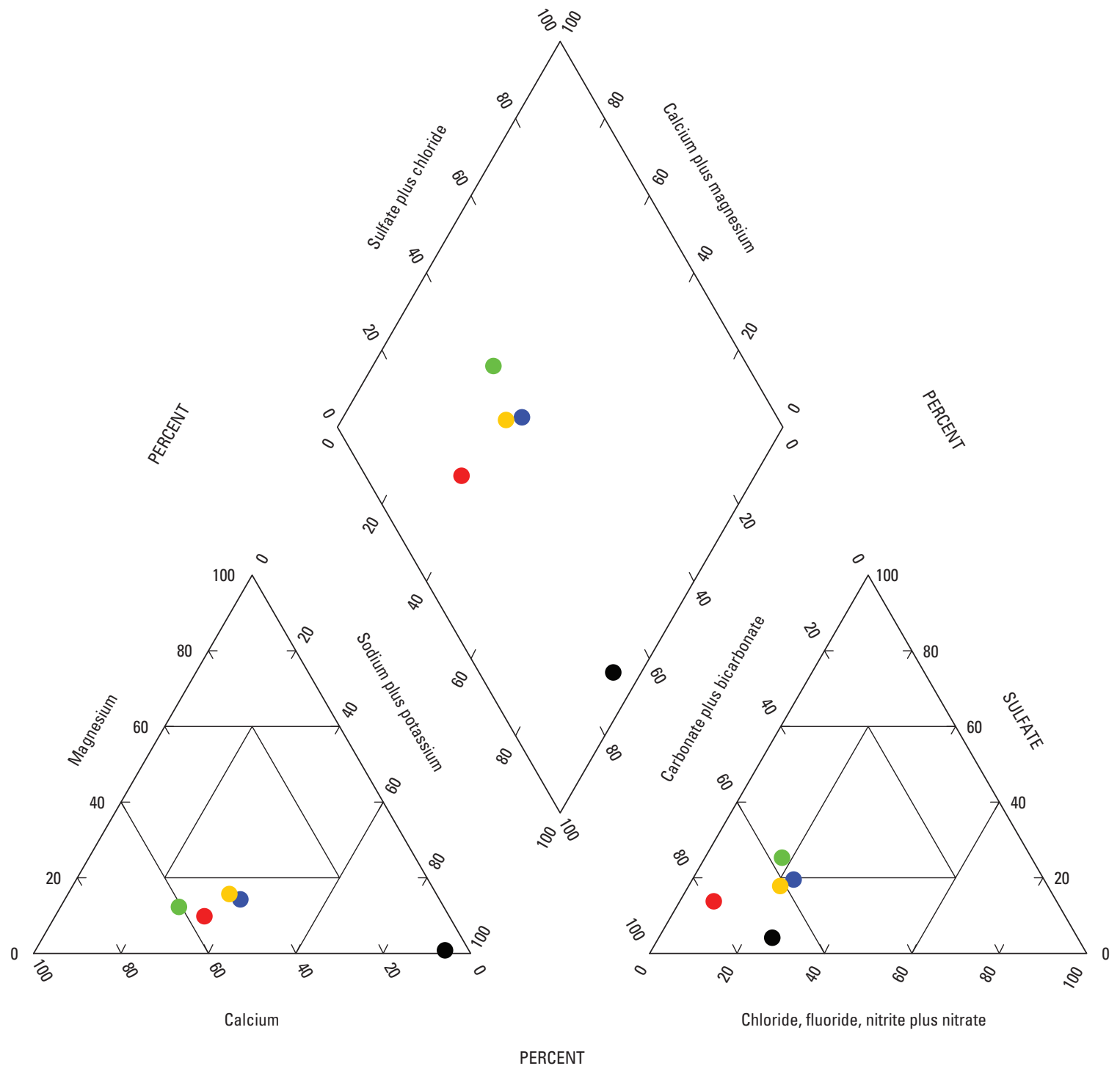

EXPLANATION

Site and well number

FOG2-5

- FOG2-4

- FOG2-3

- FOG2-2

FOG2-1

Figure 17. Major-ion chemistry of water from multiple-well monitoring site F0G2 (1S/4W-29K1-5), San Bernardino County, California, 2007. 


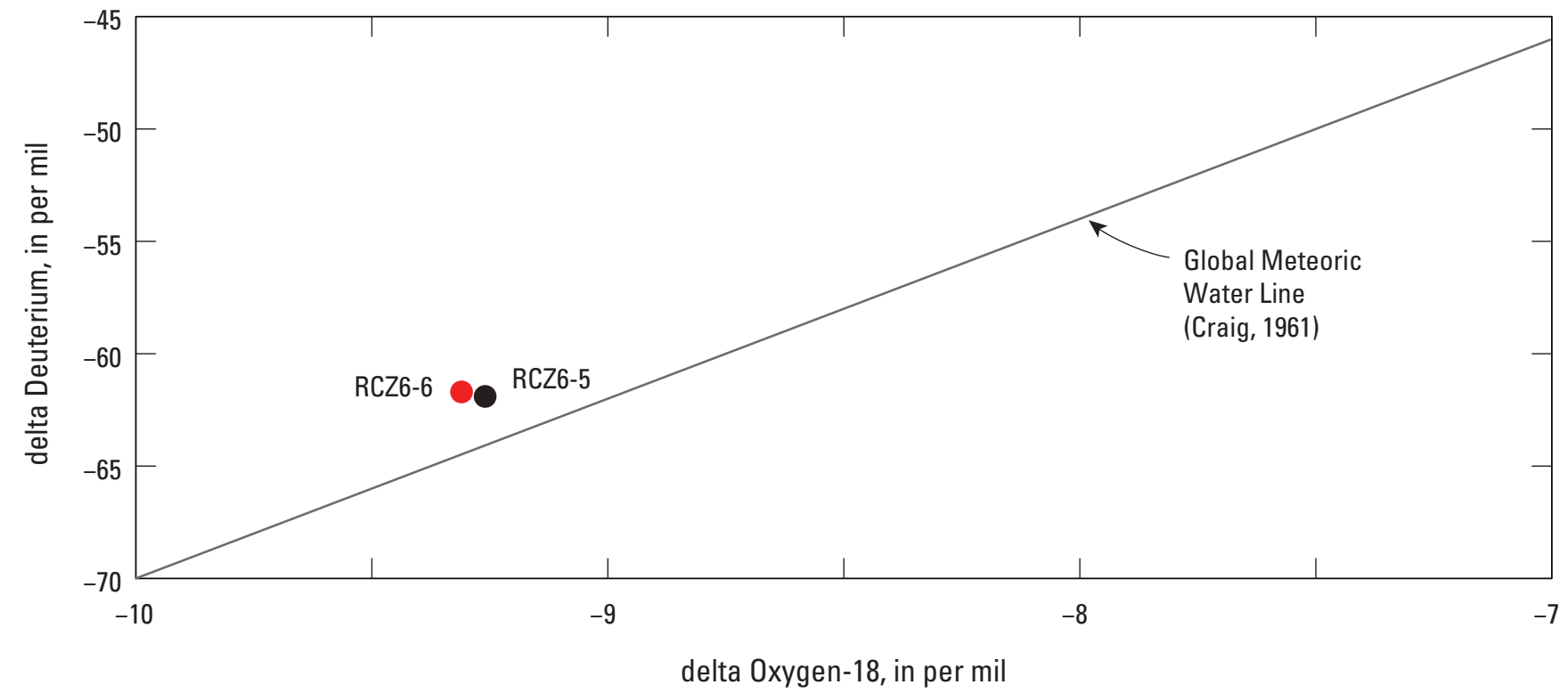

Figure 18. Delta oxygen-18 and delta deuterium composition of water from multiple-well monitoring site RCZ6 (1N/5W-17L1-6), San Bernardino County, California, 2011.

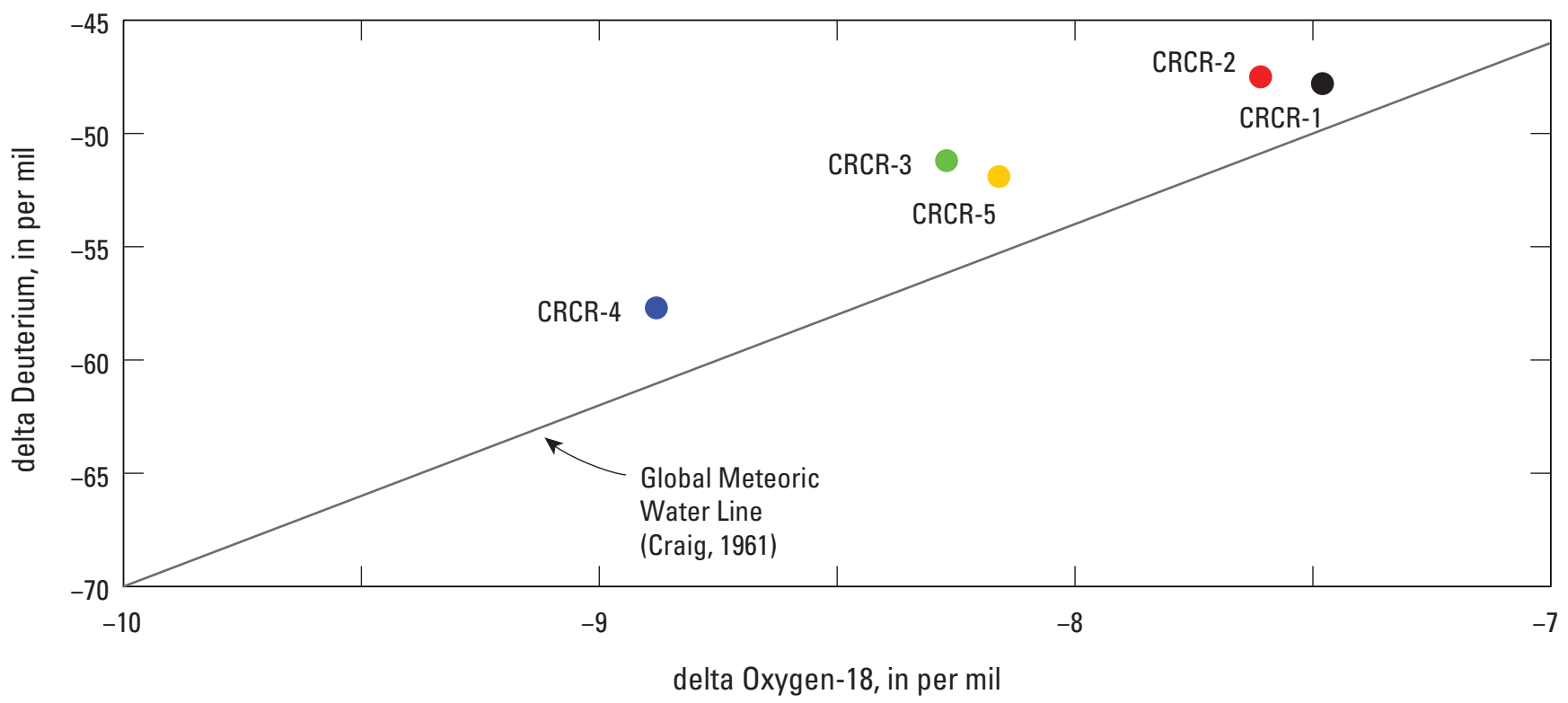

Figure 19. Delta oxygen-18 and delta deuterium composition of water from multiple-well monitoring site CRCR (1S/5W-03A3-8), San Bernardino County, California, 2007. 


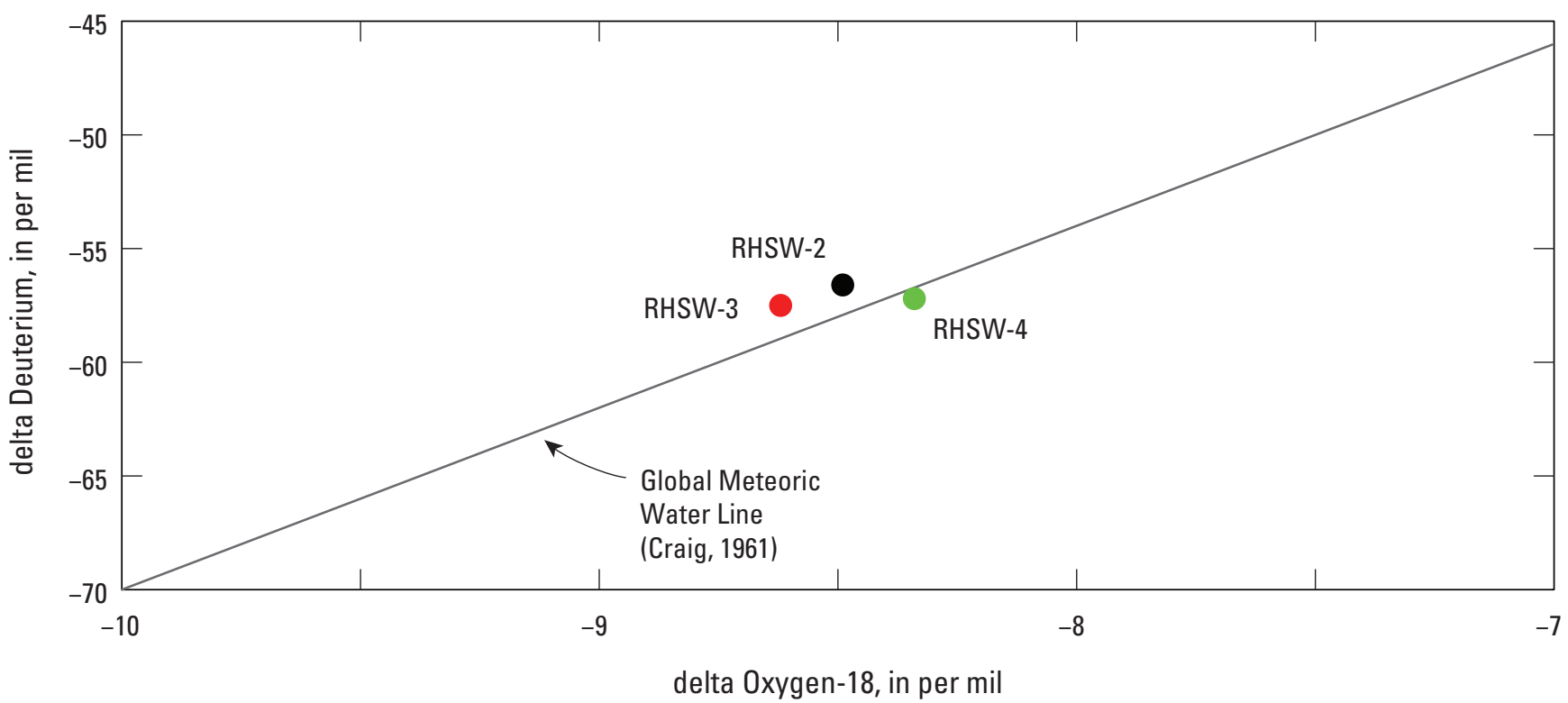

Figure 20. Delta oxygen-18 and delta deuterium composition of water from multiple-well monitoring site RHSW (1S/5W-13B1-5), San Bernardino County, California, 2007.

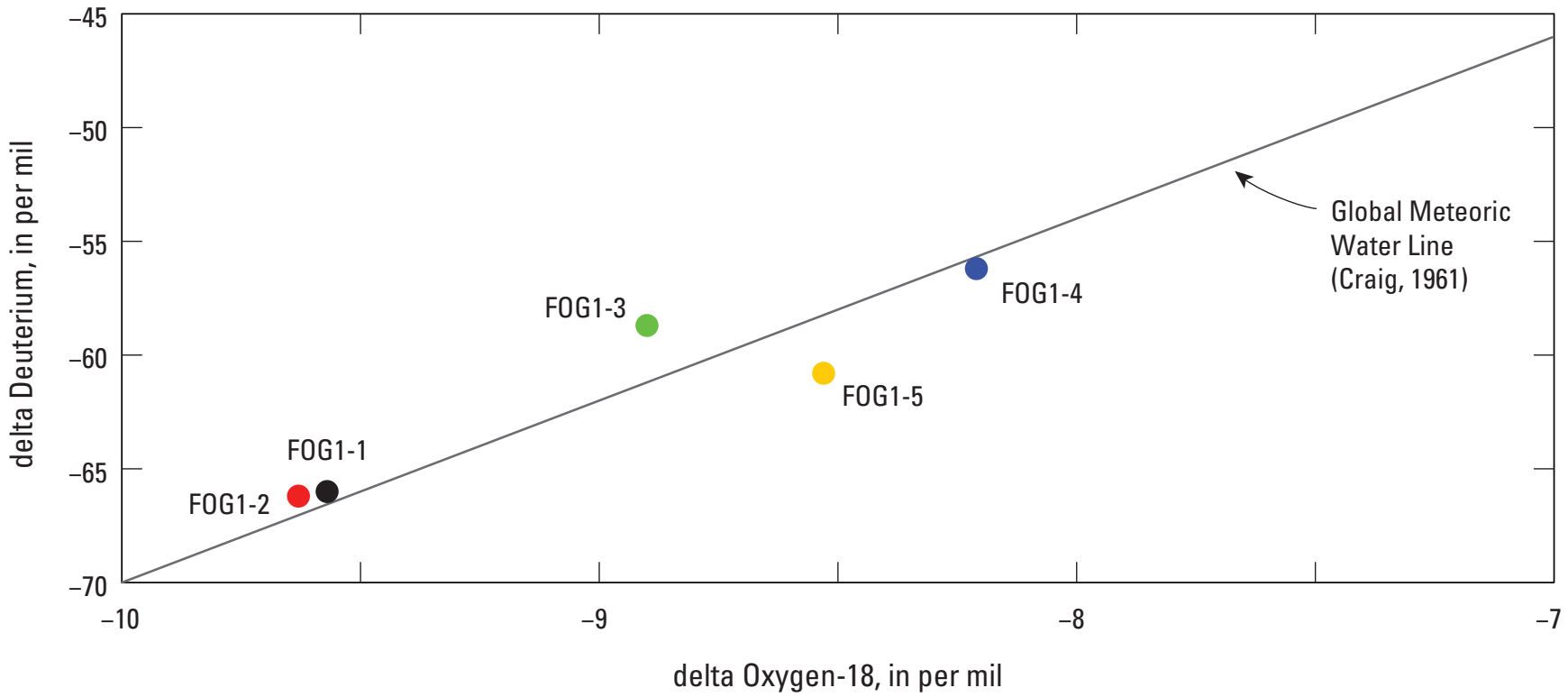

Figure 21. Delta oxygen-18 and delta deuterium composition of water from multiple-well monitoring site F0G1 (1S/4W-29H4-8), San Bernardino County, California, 2007. 


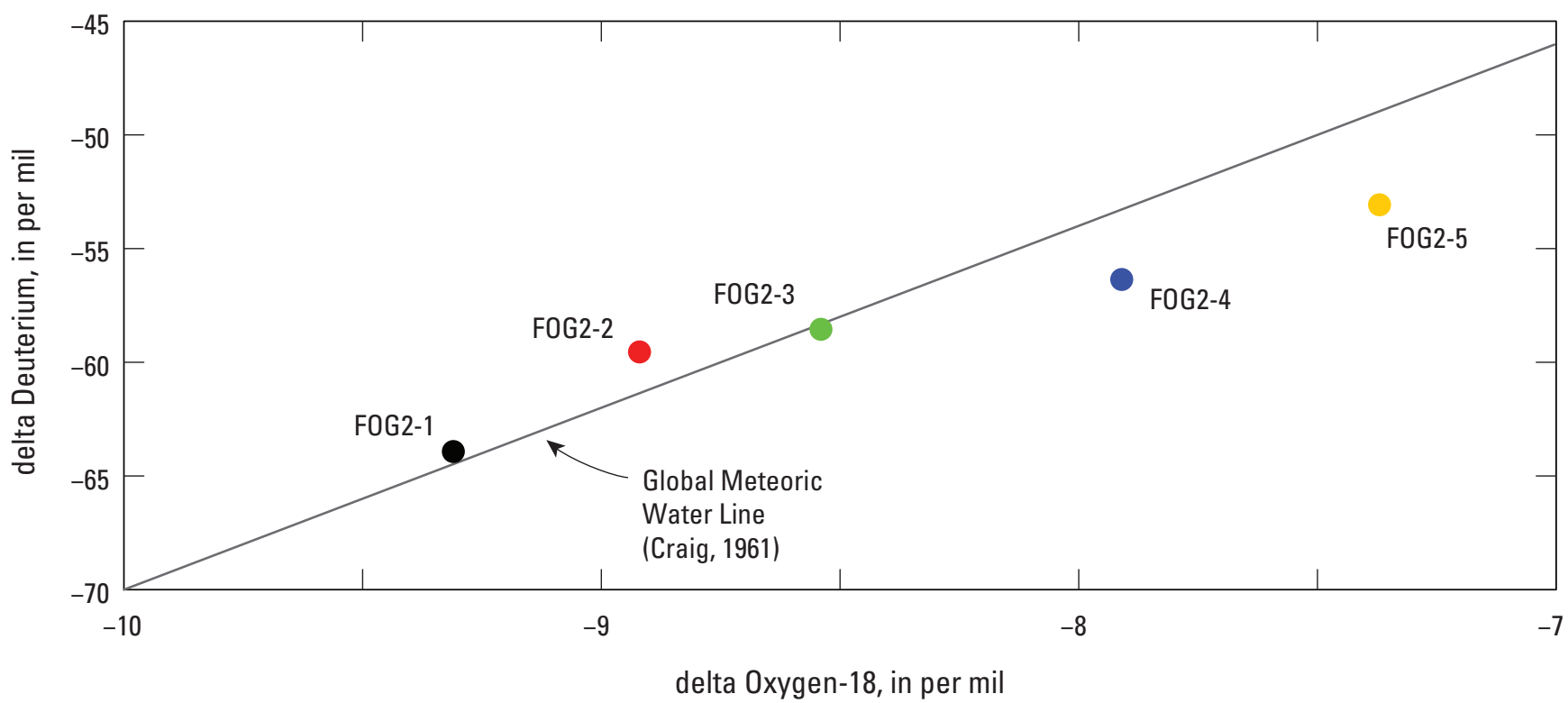

Figure 22. Delta oxygen-18 and delta deuterium composition of water from multiple-well monitoring site F0G2 (1S/4W-29K1-5), San Bernardino County, California, 2007. 


\section{Tables}




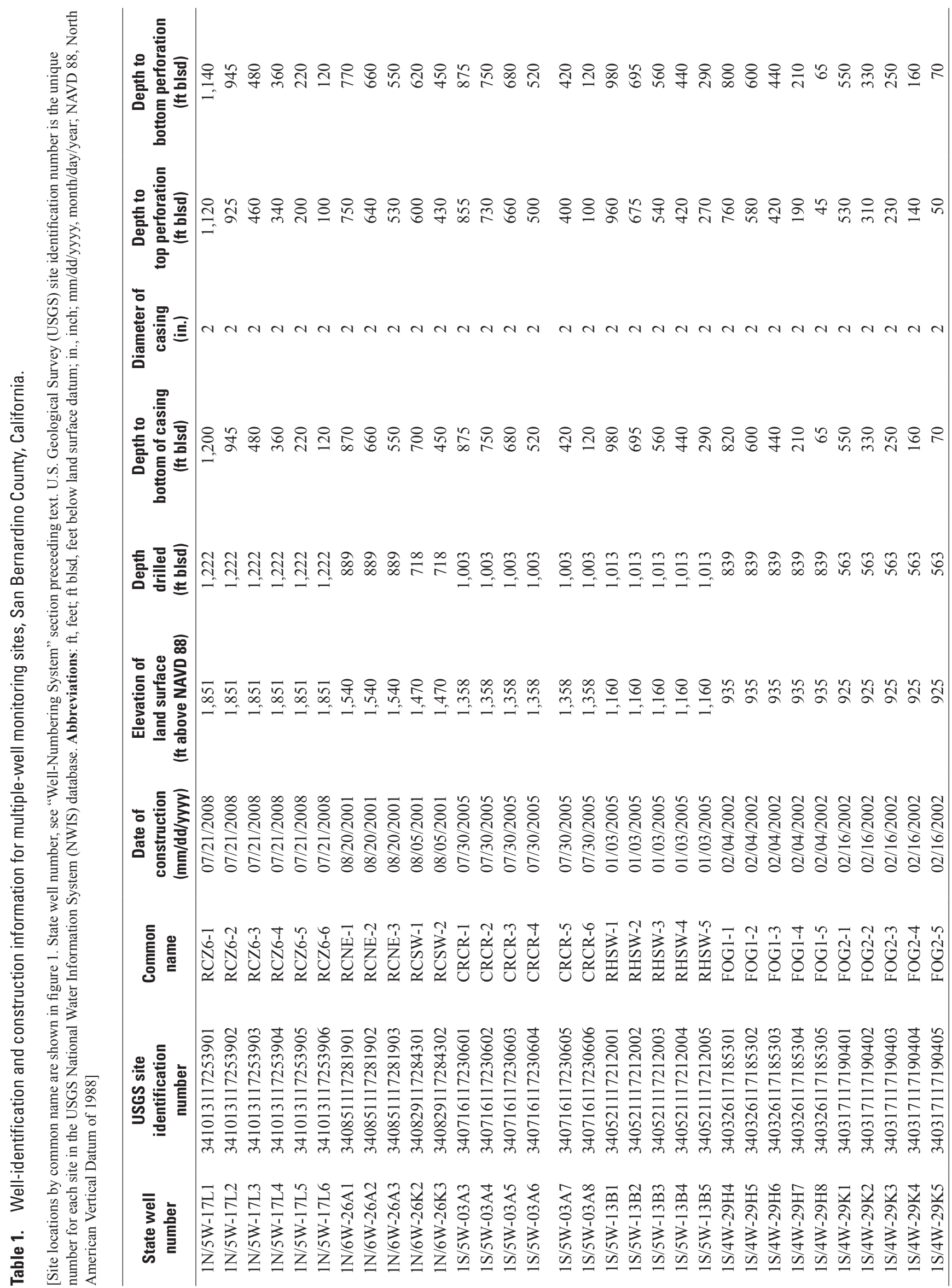


Table 2. Lithologic log from sieved drill cuttings (125- $\mu \mathrm{m}$ screen opening) from multiple-well monitoring site RCZ6 (1N/5W-17L1-6), San Bernardino County, California.

[Abbreviations: ft, feet; $\mu \mathrm{m}$, micrometer]

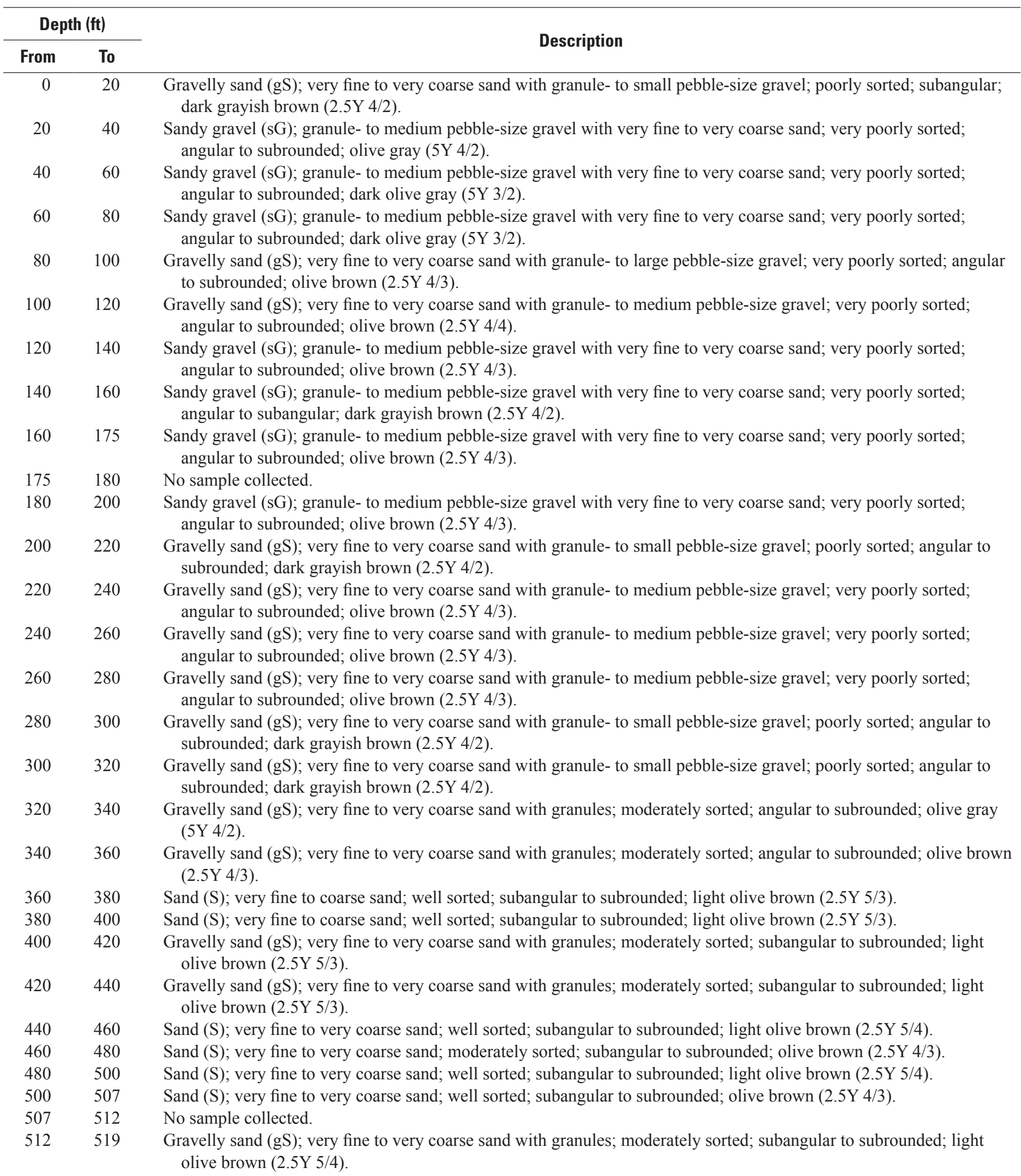


Table 2. Lithologic log from sieved drill cuttings (125- $\mu \mathrm{m}$ screen opening) from multiple-well monitoring site RCZ6 (1N/5W-17L1-6), San Bernardino County, California.-Continued

[Abbreviations: $\mathrm{ft}$, feet; $\mu \mathrm{m}$, micrometer]

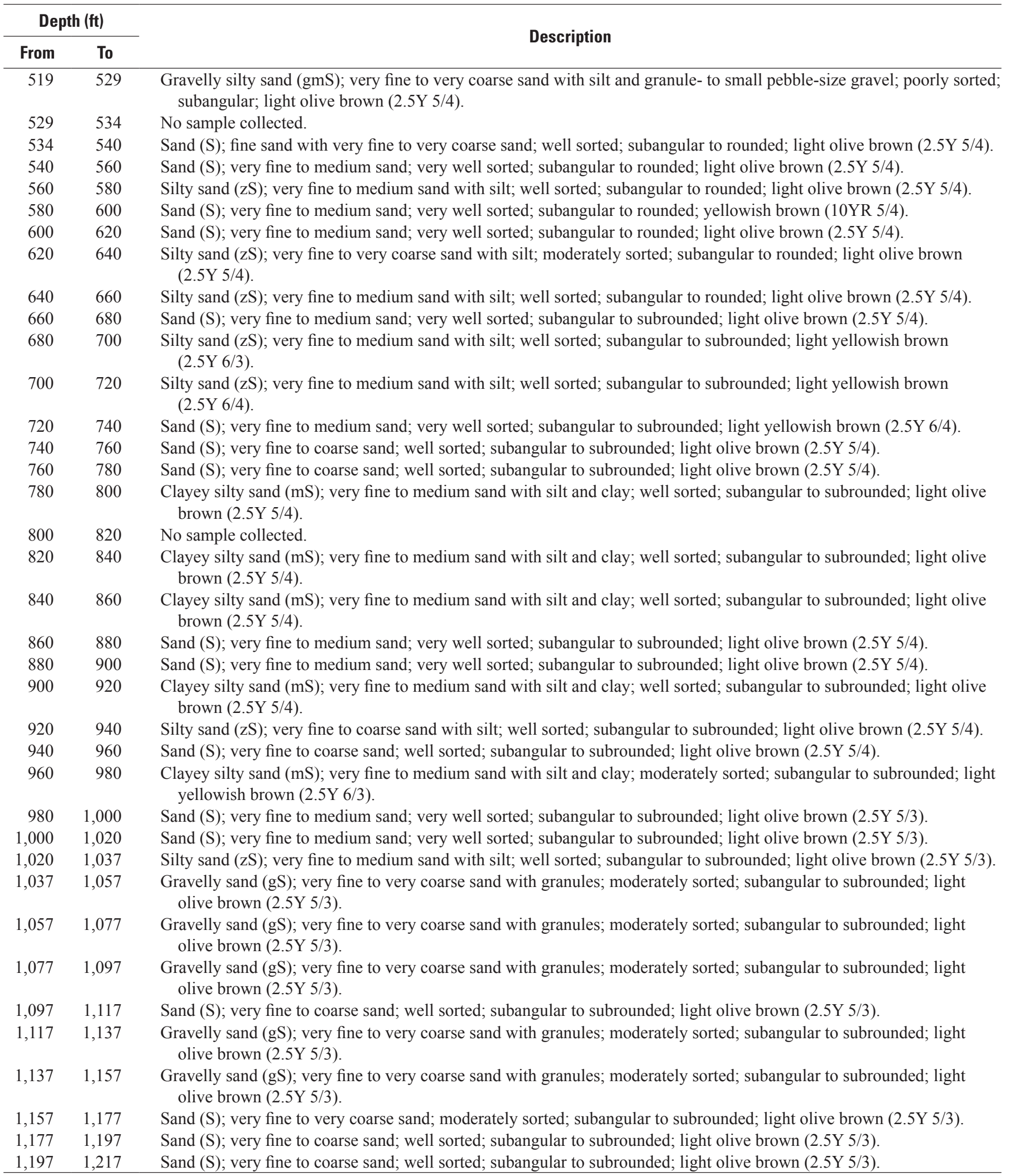


Table 3. Lithologic log from shaker drill cuttings (250- $\mu \mathrm{m}$ screen opening) from multiple-well monitoring site RCZ6 (1N/5W-17L1-6), San Bernardino County, California.

[Abbreviations: ft, feet; $\mu \mathrm{m}$, micrometer]

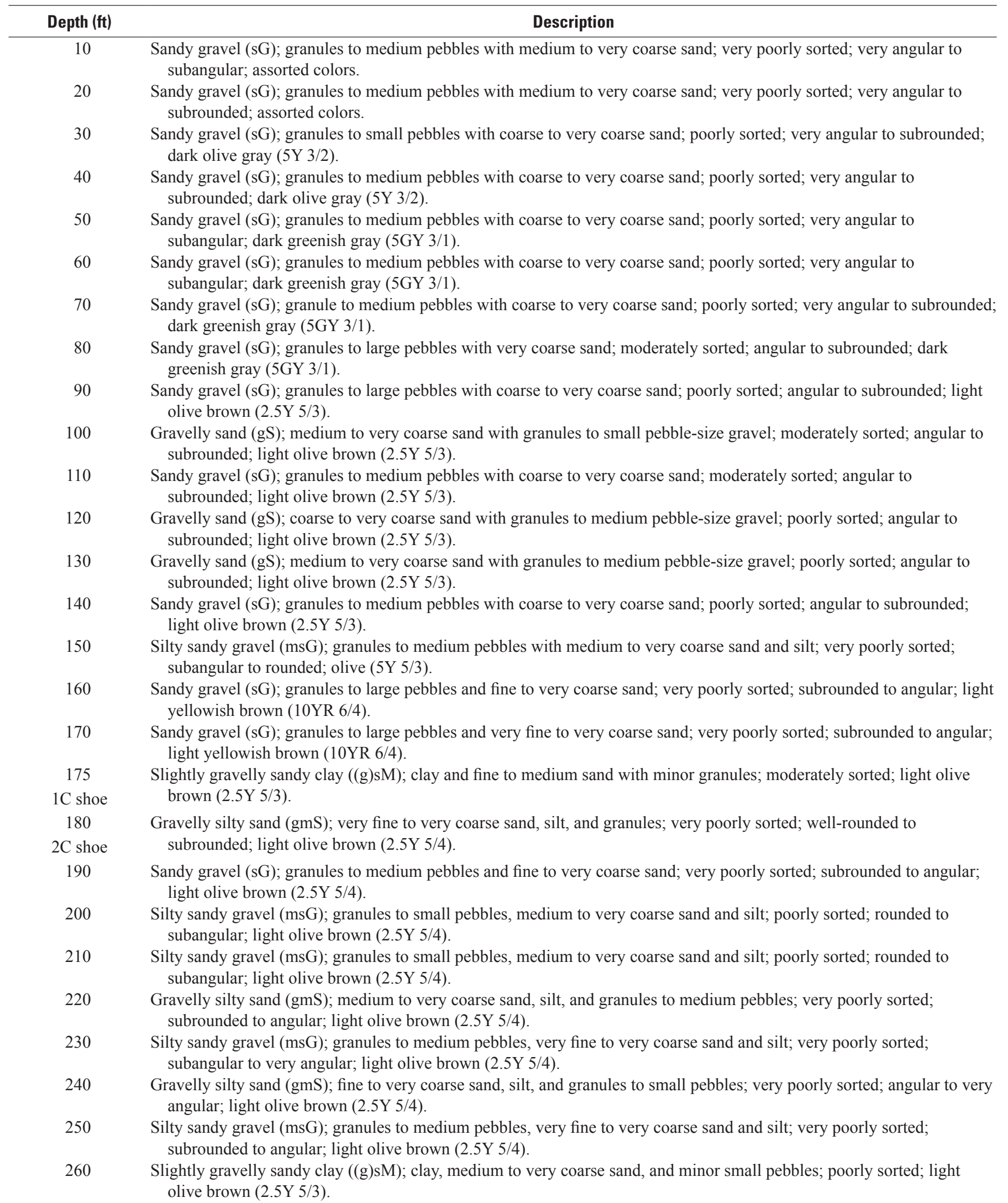


Table 3. Lithologic log from shaker drill cuttings $(250-\mu \mathrm{m}$ screen opening) from multiple-well monitoring site RCZ6 (1N/5W-17L1-6), San Bernardino County, California.-Continued

[Abbreviations: ft, feet; $\mu \mathrm{m}$, micrometer]

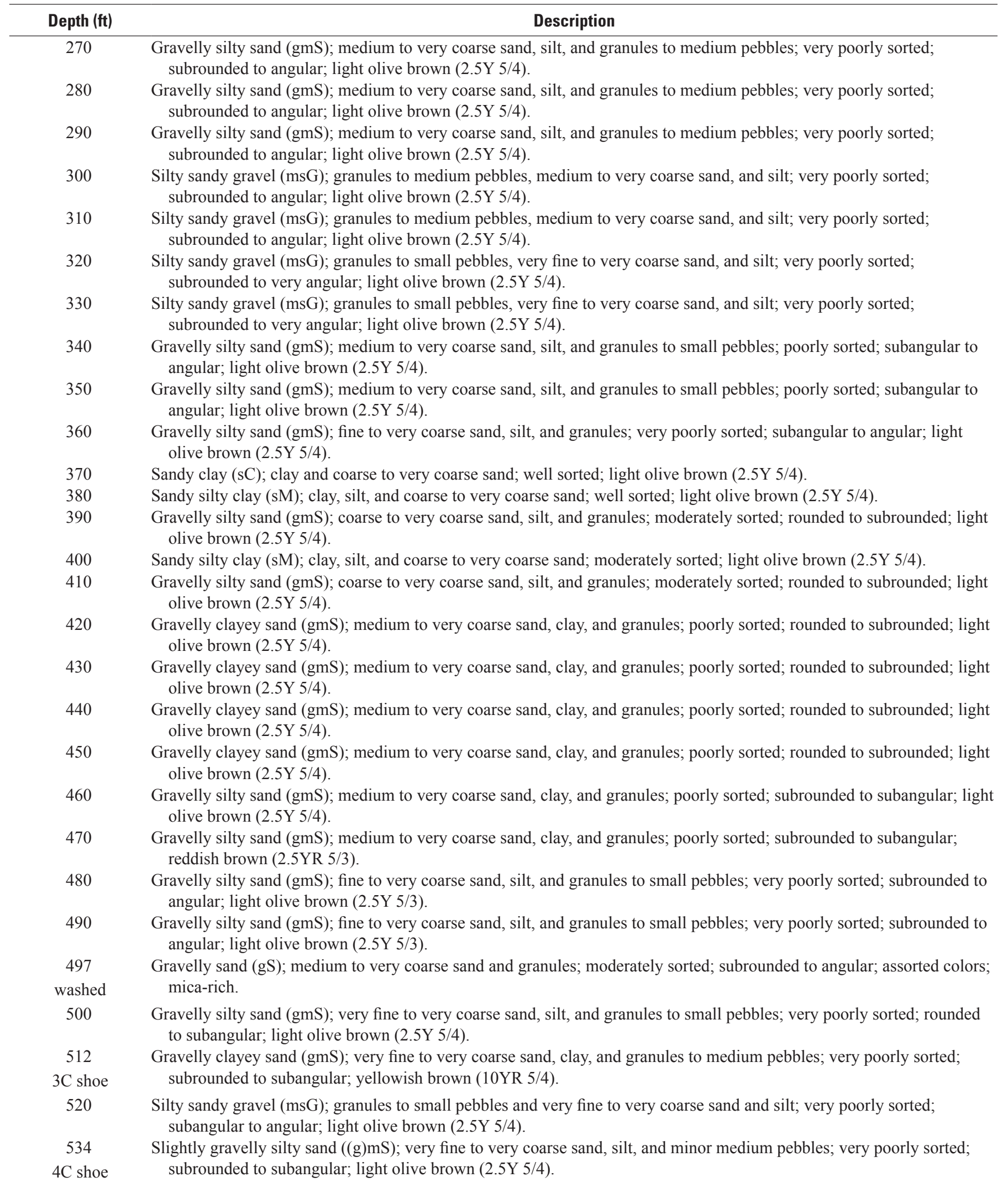


Table 3. Lithologic log from shaker drill cuttings (250- $\mu \mathrm{m}$ screen opening) from multiple-well monitoring site RCZ6 (1N/5W-17L1-6), San Bernardino County, California.-Continued

[Abbreviations: $\mathrm{ft}$, feet; $\mu \mathrm{m}$, micrometer]

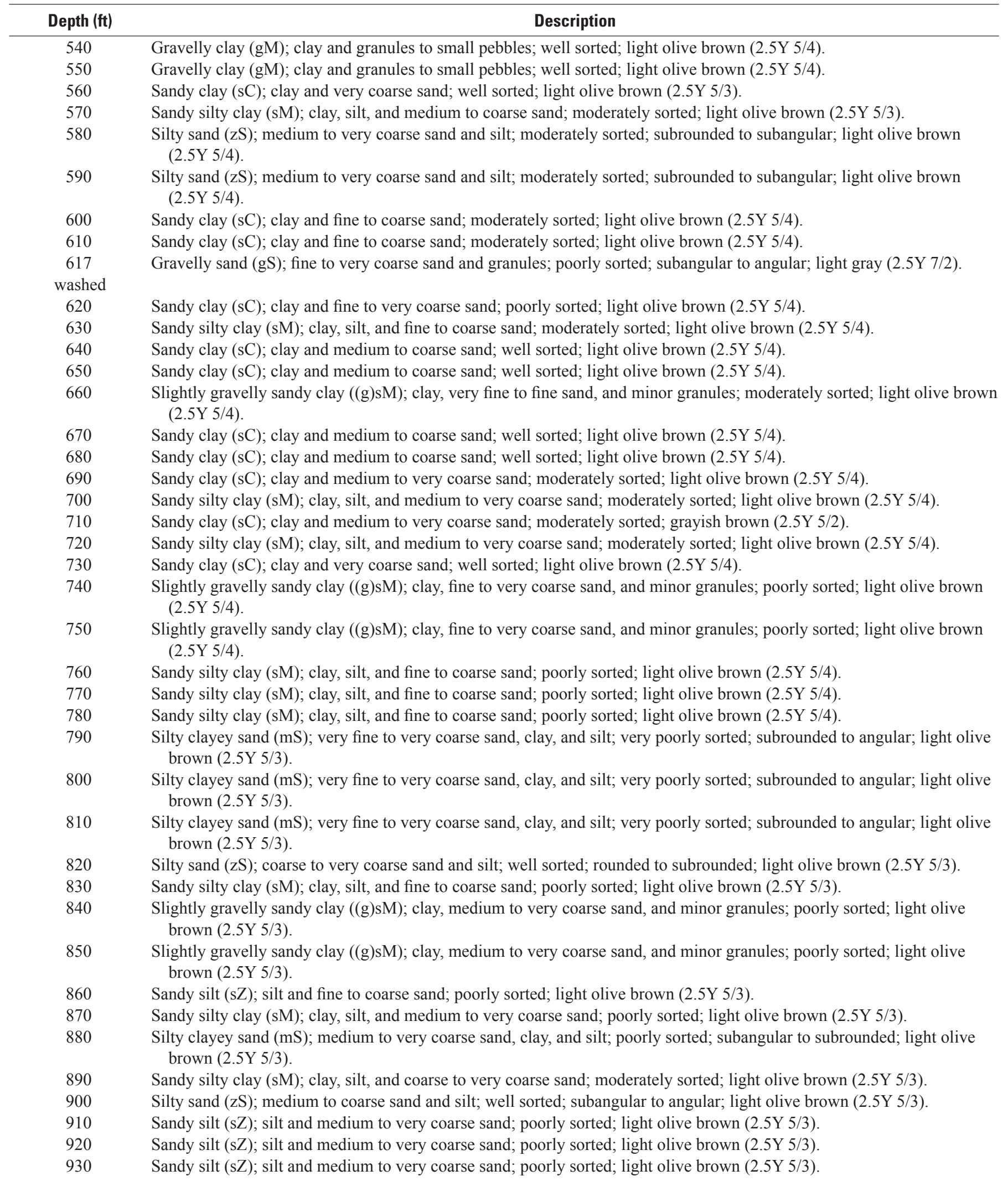


Table 3. Lithologic log from shaker drill cuttings (250- $\mu \mathrm{m}$ screen opening) from multiple-well monitoring site RCZ6 (1N/5W-17L1-6), San Bernardino County, California.-Continued

[Abbreviations: ft, feet; $\mu \mathrm{m}$, micrometer]

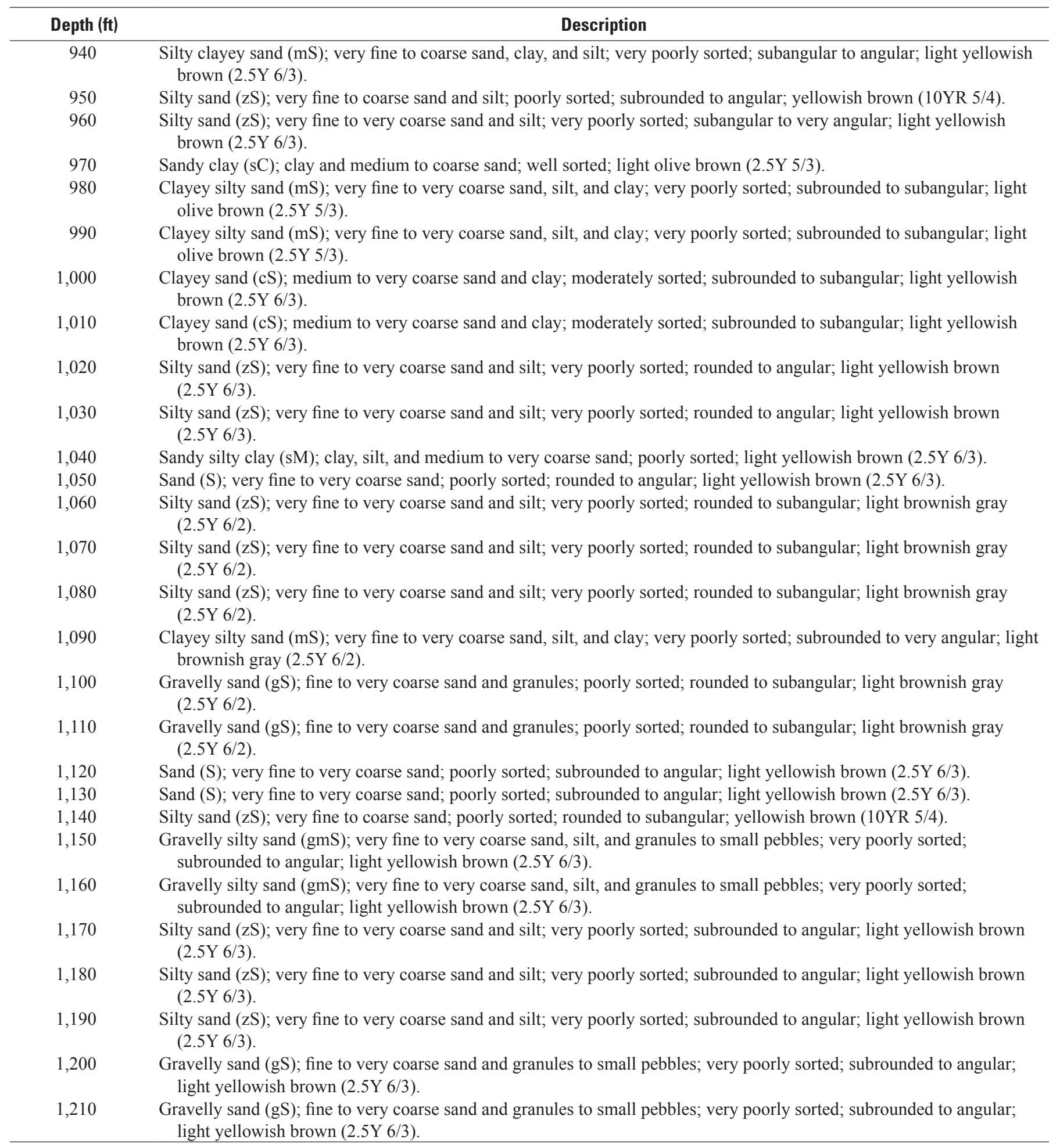


Table 4. Lithologic log from sieved drill cuttings (125- $\mu \mathrm{m}$ screen opening) from multiple-well monitoring site RCNE (1N/6W-26A1-3), San Bernardino County, California.

[Abbreviations: $\mathrm{ft}$, feet; mm, millimeter; $<$, less than; $\mu \mathrm{m}$, micrometer]

\begin{tabular}{|c|c|c|}
\hline \multicolumn{2}{|c|}{ Depth (ft) } & \multirow{2}{*}{ Description } \\
\hline From & To & \\
\hline 0 & 18 & Gravelly sand (gS); medium sand to granules; moderately sorted; angular to subangular; olive (5Y 5/3). \\
\hline 38 & 58 & $\begin{array}{l}\text { Gravelly sand (gS); medium sand to pebbles; moderately sorted; subangular; olive gray (5Y 5/2); pebbles are }<8 \mathrm{~mm} \text { in } \\
\text { diameter. }\end{array}$ \\
\hline 58 & 78 & $\begin{array}{l}\text { Gravelly sand (gS); medium sand to pebbles; moderately sorted; subangular; olive gray (5Y 5/2); pebbles are }<8 \mathrm{~mm} \text { in } \\
\text { diameter. }\end{array}$ \\
\hline 98 & 118 & $\begin{array}{l}\text { Gravelly sand (gS); medium sand to pebbles; moderately sorted; angular to subangular; olive gray (5Y 5/2); pebbles are } \\
<25 \mathrm{~mm} \text { in diameter. }\end{array}$ \\
\hline 118 & 138 & $\begin{array}{l}\text { Gravelly sand (gS); medium sand to pebbles; moderately sorted; angular to subangular; olive gray (5Y 5/2); pebbles are } \\
<12 \mathrm{~mm} \text { in diameter. }\end{array}$ \\
\hline 160 & 170 & Gravelly sand (gS); very fine sand to granules; poorly sorted; angular to subangular; yellowish brown (10YR 5/4). \\
\hline 170 & 190 & $\begin{array}{l}\text { Gravelly sand (gS); fine sand to pebbles; poorly sorted; angular to subangular; light yellowish brown (10YR 6/4); } \\
\text { pebbles are }<10 \mathrm{~mm} \text { in diameter. }\end{array}$ \\
\hline 190 & 210 & $\begin{array}{l}\text { Gravelly sand (gS); medium sand to pebbles; moderately sorted; subangular; light olive brown (2.5Y 5/4); pebbles are } \\
<8 \mathrm{~mm} \text { in diameter. }\end{array}$ \\
\hline 210 & 230 & $\begin{array}{l}\text { Gravelly sand (gS); fine sand to pebbles; poorly sorted; angular to subangular; light olive brown (2.5Y 5/4); pebbles are } \\
\quad<10 \mathrm{~mm} \text { in diameter. }\end{array}$ \\
\hline 230 & 250 & $\begin{array}{l}\text { Gravelly sand (gS); fine sand to pebbles; poorly sorted; angular to subangular; light olive brown (2.5Y } 5 / 3) \text {; pebbles are } \\
<8 \mathrm{~mm} \text { in diameter. }\end{array}$ \\
\hline 250 & 270 & $\begin{array}{l}\text { Slightly gravelly silty clayey sand ((g)mS); very fine to very coarse sand with silt and clay and occasional granules; very } \\
\text { poorly sorted; subangular; yellowish brown (10YR 5/4). }\end{array}$ \\
\hline 270 & 290 & Gravelly sand (gS); fine sand to granules; moderately sorted; subangular; light olive brown (2.5Y 5/4). \\
\hline 290 & 310 & $\begin{array}{l}\text { Gravelly sand (gS); medium sand to pebbles; moderately sorted; subangular; light olive brown (2.5Y 5/4); pebbles are } \\
<15 \mathrm{~mm} \text { in diameter. }\end{array}$ \\
\hline 310 & 318 & Gravelly sand (gS); fine sand to granules; moderately sorted; subangular; yellowish brown (10YR 5/4). \\
\hline 318 & 338 & $\begin{array}{l}\text { Gravelly silty sand (gmS); fine sand to granules with silt; poorly sorted; subangular to subrounded; light yellowish } \\
\text { brown }(2.5 \mathrm{Y} 6 / 4) \text {. }\end{array}$ \\
\hline 338 & 358 & Sand (S); very fine to very coarse sand; moderately sorted; subangular; light yellowish brown (2.5Y 6/4). \\
\hline 358 & 378 & Gravelly sand (gS); very fine sand to granules; poorly sorted; subangular; light yellowish brown (2.5Y 6/4). \\
\hline 378 & 398 & Sand (S); very fine to very coarse sand; moderately sorted; subangular; yellowish brown (10YR 5/4). \\
\hline 398 & 418 & Sand (S); very fine to coarse sand; moderately sorted; subangular; light yellowish brown (2.5Y 6/4). \\
\hline 418 & 438 & Sand (S); very fine to coarse sand; moderately sorted; subangular; light yellowish brown (2.5Y 6/4). \\
\hline 438 & 458 & Sand (S); very fine to coarse sand; moderately sorted; subangular; light yellowish brown (2.5Y 6/4). \\
\hline 458 & 498 & No sample collected. \\
\hline 498 & 518 & Silty sand (zS); silt to very coarse sand; poorly sorted; subangular; light yellowish brown (2.5Y 6/4). \\
\hline 518 & 538 & Sand (S); very fine to very coarse sand; moderately sorted; subangular to subrounded; light yellowish brown (2.5Y $6 / 4)$. \\
\hline 538 & 558 & Sand (S); very fine to very coarse sand; moderately sorted; subangular to subrounded; light yellowish brown (2.5Y 6/4). \\
\hline 558 & 578 & Sand (S); very fine to very coarse sand; moderately sorted; subangular to subrounded; light yellowish brown (2.5Y 6/4). \\
\hline 578 & 598 & Sand (S); very fine to very coarse sand; moderately sorted; subangular to subrounded; light yellowish brown (2.5Y 6/4). \\
\hline 598 & 618 & Sand (S); very fine to very coarse sand; moderately sorted; subangular to subrounded; light yellowish brown (2.5Y 6/4). \\
\hline 618 & 638 & Sand (S); very fine to very coarse sand; moderately sorted; subangular to subrounded; light yellowish brown (2.5Y $6 / 4)$. \\
\hline 638 & 658 & Sand (S); fine to coarse sand; moderately sorted; subangular; light olive brown (2.5Y 5/4). \\
\hline 658 & 670 & No sample collected. \\
\hline 670 & 690 & Sand (S); fine to very coarse sand; moderately sorted; subangular; light olive brown (2.5Y 5/4). \\
\hline 690 & 710 & Sand (S); fine to very coarse sand; moderately sorted; subangular; light olive brown (2.5Y 5/4). \\
\hline 710 & 730 & Sand (S); fine to very coarse sand; moderately sorted; subangular to subrounded; light olive brown (2.5Y 5/4). \\
\hline 730 & 750 & Sand (S); very fine to very coarse sand; moderately sorted; subangular; light yellowish brown (2.5Y 6/4). \\
\hline
\end{tabular}




\section{Geohydrologic and Water-Quality Data in the Vicinity of the Rialto-Colton Fault, San Bernardino, California}

Table 4. Lithologic log from sieved drill cuttings (125- $\mu$ m screen opening) from multiple-well monitoring site RCNE (1N/6W-26A1-3), San Bernardino County, California._-Continued

[Abbreviations: $\mathrm{ft}$, feet; $\mathrm{mm}$, millimeter; <, less than; $\mu \mathrm{m}$, micrometer]

\begin{tabular}{|c|c|c|}
\hline \multicolumn{2}{|c|}{ Depth (ft) } & Description \\
\hline 750 & 770 & Sand (S); fine to very coarse sand; moderately sorted; subangular; light olive brown (2.5Y 5/4). \\
\hline 786 & 797 & $\begin{array}{l}\text { Silty clayey sand (mS); medium to coarse sand with silt and clay; moderately sorted; subangular; light olive brown } \\
\text { (2.5Y 5/4). }\end{array}$ \\
\hline 797 & 817 & $\begin{array}{l}\text { Silty clayey sand (mS); medium to coarse sand with silt and clay; moderately sorted; subangular; light olive brown } \\
\text { ( } 2.5 \mathrm{Y} 5 / 4) \text {. }\end{array}$ \\
\hline 817 & 837 & $\begin{array}{l}\text { Silty clayey sand }(\mathrm{mS}) \text {; medium to coarse sand with some silt and clay; moderately sorted; subangular; light olive } \\
\text { brown }(2.5 \mathrm{Y} 5 / 4) \text {. }\end{array}$ \\
\hline
\end{tabular}


Table 5. Lithologic log from shaker drill cuttings (250- $\mu \mathrm{m}$ screen opening) from multiple-well monitoring site RCNE (1N/6W-26A1-3), San Bernardino County, California.

[Abbreviations: $\mathrm{ft}$, feet; $\mathrm{mm}$, millimeter; $<$, less than; $\mu \mathrm{m}$, micrometer]

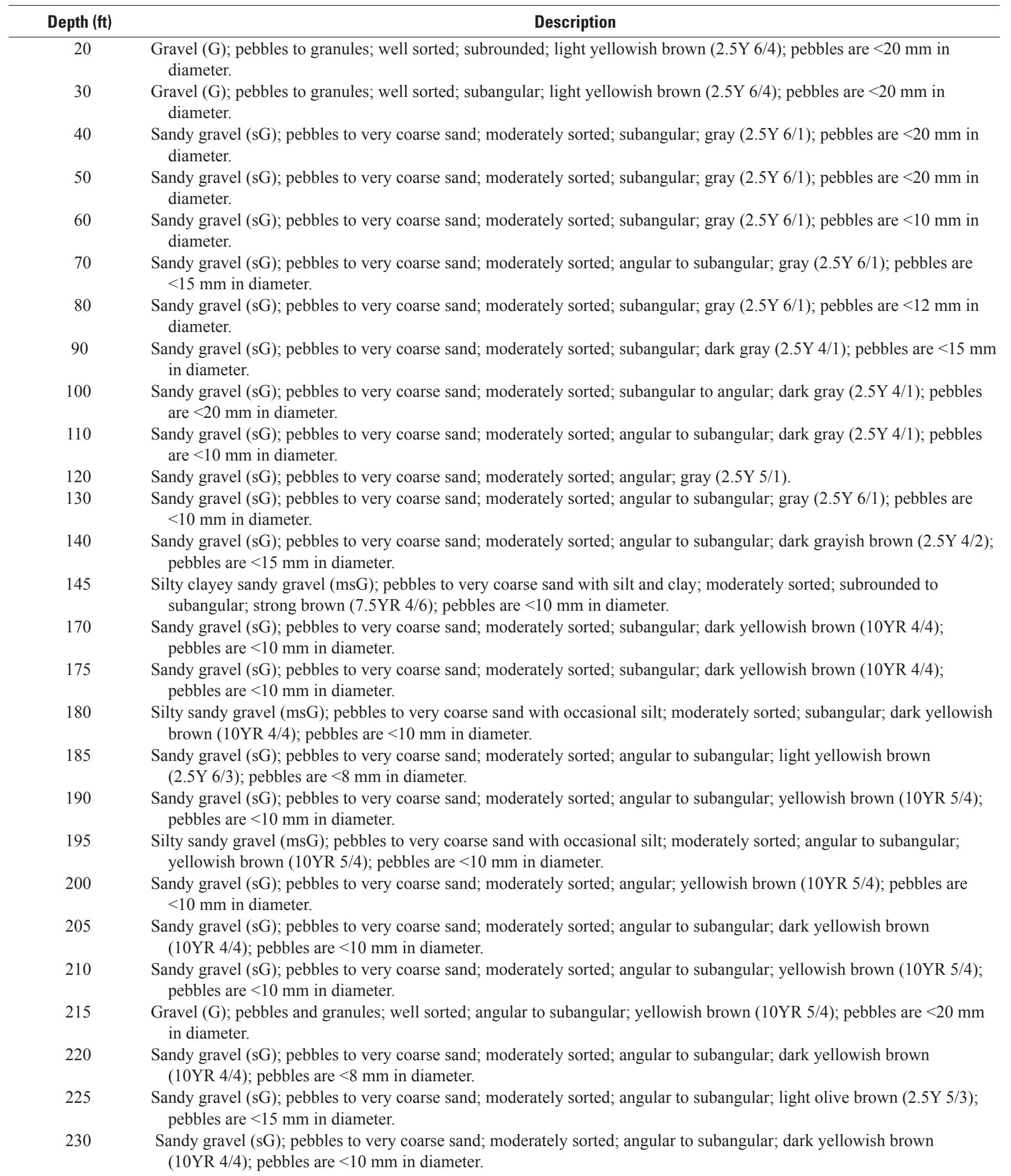


Table 5. Lithologic log from shaker drill cuttings (250- $\mu$ m screen opening) from multiple-well monitoring site RCNE (1N/6W-26A1-3), San Bernardino County, California.-Continued

[Abbreviations: ft, feet; mm, millimeter; $<$, less than; $\mu \mathrm{m}$, micrometer]

\begin{tabular}{|c|c|}
\hline Depth (ft) & Description \\
\hline 240 & $\begin{array}{l}\text { Sandy gravel (sG); pebbles to very coarse sand; moderately sorted; angular to subangular; light olive brown (2.5Y 5/3); } \\
\text { pebbles are }<10 \mathrm{~mm} \text { in diameter. }\end{array}$ \\
\hline 250 & $\begin{array}{l}\text { Sandy gravel (sG); pebbles to very coarse sand; moderately sorted; subangular; light yellowish brown (10YR 6/4); } \\
\text { pebbles are }<10 \mathrm{~mm} \text { in diameter. }\end{array}$ \\
\hline 255 & $\begin{array}{l}\text { Sandy gravel (sG); pebbles to very coarse sand; moderately sorted; subangular; light yellowish brown (10YR 6/4); } \\
\text { pebbles are }<15 \mathrm{~mm} \text { in diameter. }\end{array}$ \\
\hline 265 & $\begin{array}{l}\text { Silty sandy gravel (msG); pebbles to very coarse sand with some silt; moderately sorted; subangular; yellowish brown } \\
(10 \mathrm{YR} 5 / 6) \text {; pebbles are }<10 \mathrm{~mm} \text { in diameter. }\end{array}$ \\
\hline 270 & $\begin{array}{l}\text { Sandy gravel (sG); pebbles to very coarse sand; moderately sorted; angular; dark yellowish brown (10YR 4/4); pebbles } \\
\text { are }<10 \mathrm{~mm} \text { in diameter. }\end{array}$ \\
\hline 280 & $\begin{array}{l}\text { Sandy gravel (sG); pebbles to very coarse sand; moderately sorted; angular to subangular; dark yellowish brown } \\
\text { (10YR 4/4); pebbles are }<10 \mathrm{~mm} \text { in diameter. }\end{array}$ \\
\hline 300 & $\begin{array}{l}\text { Gravelly sand (gS); very coarse sand to pebbles; moderately sorted; angular; light olive brown (2.5Y 5/3); pebbles are } \\
\quad<10 \mathrm{~mm} \text { in diameter. }\end{array}$ \\
\hline 305 & $\begin{array}{l}\text { Sandy gravel }(\mathrm{sG}) \text {; pebbles to very coarse sand; moderately sorted; angular to subangular; light olive brown }(2.5 \mathrm{Y} 5 / 3) \text {; } \\
\text { pebbles are }<15 \mathrm{~mm} \text { in diameter. }\end{array}$ \\
\hline 310 & $\begin{array}{l}\text { Sandy gravel (sG); pebbles to very coarse sand; moderately sorted; subangular; light olive brown (2.5Y 5/3); pebbles are } \\
\quad<10 \mathrm{~mm} \text { in diameter. }\end{array}$ \\
\hline 320 & $\begin{array}{l}\text { Sandy gravel (sG); pebbles to very coarse sand; moderately sorted; angular; light olive brown (2.5Y 5/3); pebbles are } \\
<15 \mathrm{~mm} \text { in diameter. }\end{array}$ \\
\hline 325 & $\begin{array}{l}\text { Gravelly silty sand (gmS); coarse sand to pebbles with silt to very fine sand; poorly sorted; subangular to subrounded; } \\
\text { dark yellowish brown (10YR 4/4); pebbles are }<15 \mathrm{~mm} \text { in diameter. }\end{array}$ \\
\hline 330 & $\begin{array}{l}\text { Gravelly silty sand (gmS); coarse sand to pebbles with silt to very fine sand; poorly sorted; subangular to subrounded; } \\
\text { light yellowish brown }(2.5 \mathrm{Y} 6 / 4) \text {; pebbles are }<10 \mathrm{~mm} \text { in diameter. }\end{array}$ \\
\hline 350 & $\begin{array}{l}\text { Gravelly sand (gS); very coarse sand to pebbles; moderately sorted; subangular to subrounded; light yellowish brown } \\
(2.5 \mathrm{Y} 6 / 4) \text {; pebbles are }<10 \mathrm{~mm} \text { in diameter. }\end{array}$ \\
\hline 355 & $\begin{array}{l}\text { Gravelly sand (gS); very coarse sand to pebbles; moderately sorted; subangular to subrounded; light yellowish brown } \\
\quad(2.5 \mathrm{Y} 6 / 4) \text {; pebbles are }<10 \mathrm{~mm} \text { in diameter. }\end{array}$ \\
\hline 365 & $\begin{array}{l}\text { Gravelly sand (gS); coarse sand to pebbles; moderately sorted; subangular; light yellowish brown }(2.5 \mathrm{Y} 6 / 4) \text {; pebbles are } \\
\quad<10 \mathrm{~mm} \text { in diameter. }\end{array}$ \\
\hline 370 & Gravelly silty sand (gmS); coarse sand to granules with some silt; moderately sorted; subangular; olive brown (2.5Y 4/4). \\
\hline 380 & $\begin{array}{l}\text { Gravelly silty sand (gmS); very coarse sand to granules with some silt; moderately sorted; subangular; olive brown } \\
(2.5 \mathrm{Y} 4 / 4) \text {. }\end{array}$ \\
\hline 390 & $\begin{array}{l}\text { Gravelly clayey silty sand (gmS); very coarse sand to granules with silt and clay; moderately sorted; subangular; dark } \\
\text { yellowish brown (10YR 4/4). }\end{array}$ \\
\hline 395 & $\begin{array}{l}\text { Silty clayey sand (mS); coarse to very coarse sand with silt and clay; moderately sorted; subangular to subrounded; dark } \\
\text { yellowish brown (10YR 4/4). }\end{array}$ \\
\hline 400 & $\begin{array}{l}\text { Gravelly silty sand (gmS); very coarse sand to pebbles with silt; moderately sorted; subangular; dark yellowish brown } \\
\quad(10 \mathrm{YR} 4 / 4) \text {; pebbles are }<10 \mathrm{~mm} \text { in diameter. }\end{array}$ \\
\hline 405 & $\begin{array}{l}\text { Gravelly silty clayey sand (gmS); very coarse sand to pebbles with silt and clay; moderately sorted; subangular; dark } \\
\text { yellowish brown (10YR 4/4); pebbles are }<10 \mathrm{~mm} \text { in diameter. }\end{array}$ \\
\hline 410 & Silty sand (zS); coarse to very coarse sand with silt; moderately sorted; subangular; light olive brown (2.5Y 5/4). \\
\hline
\end{tabular}


Table 5. Lithologic log from shaker drill cuttings (250- $\mu \mathrm{m}$ screen opening) from multiple-well monitoring site RCNE (1N/6W-26A1-3), San Bernardino County, California.-Continued

[Abbreviations: $\mathrm{ft}$, feet; $\mathrm{mm}$, millimeter; $<$, less than; $\mu \mathrm{m}$, micrometer]

\begin{tabular}{|c|c|}
\hline Depth (ft) & Description \\
\hline 415 & $\begin{array}{l}\text { Gravelly silty sand (gmS); very coarse sand and granules with silt; moderately sorted; subangular; light olive brown } \\
\quad(2.5 \mathrm{Y} 5 / 4) \text {. }\end{array}$ \\
\hline 420 & $\begin{array}{l}\text { Gravelly silty sand (gmS); very coarse sand and granules with silt; moderately sorted; subangular; light olive brown } \\
(2.5 \mathrm{Y} 5 / 4) \text {. }\end{array}$ \\
\hline 435 & $\begin{array}{l}\text { Gravelly silty sand (gmS); very coarse sand and granules with silt; moderately sorted; subangular to subrounded; light } \\
\text { olive brown }(2.5 \mathrm{Y} 5 / 4) \text {. }\end{array}$ \\
\hline 445 & Silty sand (zS); coarse to very coarse sand with some silt; moderately sorted; subangular; light olive brown (2.5Y 5/4). \\
\hline 455 & $\begin{array}{l}\text { Gravelly silty sand (gmS); coarse sand to granules with some silt; moderately sorted; subangular; light olive brown } \\
(2.5 \mathrm{Y} 5 / 4) \text {. }\end{array}$ \\
\hline 460 & Gravelly sand (gS); very coarse sand to granules; well sorted; subangular to subrounded; brown (10YR 4/3). \\
\hline 480 & $\begin{array}{l}\text { Gravelly sand (gS); very coarse sand to granules with occasional pebbles; moderately sorted; subangular to subrounded; } \\
\text { brown }(10 \mathrm{YR} 4 / 3) \text {. }\end{array}$ \\
\hline 490 & Gravelly sand (gS); very coarse sand to granules; well sorted; subangular to subrounded; brown (10YR 4/3). \\
\hline 500 & Gravelly sand (gS); very coarse sand to granules; well sorted; subangular to subrounded; brown (10YR 4/3). \\
\hline 510 & $\begin{array}{l}\text { Gravelly silty sand (gmS); coarse sand to granules with silt; moderately sorted; subrounded to subangular; dark yellowish } \\
\text { brown (10YR 4/4). }\end{array}$ \\
\hline 520 & Gravelly sand (gS); coarse sand to granules; moderately sorted; subangular; light yellowish brown (2.5Y 6/4). \\
\hline 530 & $\begin{array}{l}\text { Gravelly sand (gS); coarse sand to granules with occasional pebbles; moderately sorted; subangular; light yellowish } \\
\text { brown }(2.5 \mathrm{Y} 6 / 4) \text {. }\end{array}$ \\
\hline 540 & $\begin{array}{l}\text { Gravelly sand (gS); very coarse sand to pebbles; moderately sorted; subangular; light yellowish brown (2.5Y 6/4); pebbles } \\
\text { are }<15 \mathrm{~mm} \text { in diameter. }\end{array}$ \\
\hline 550 & $\begin{array}{l}\text { Gravelly sand (gS); coarse sand to pebbles; moderately sorted; subangular; light yellowish brown (2.5Y 6/4); pebbles are } \\
\quad<10 \mathrm{~mm} \text { in diameter. }\end{array}$ \\
\hline 560 & $\begin{array}{l}\text { Gravelly sand }(\mathrm{gS}) \text {; coarse sand to pebbles; moderately sorted; subangular; light yellowish brown (2.5Y 6/4); pebbles are } \\
\quad<10 \mathrm{~mm} \text { in diameter. }\end{array}$ \\
\hline 570 & $\begin{array}{l}\text { Gravelly sand (gS); coarse sand to pebbles; moderately sorted; subangular; light yellowish brown }(2.5 \mathrm{Y} 6 / 4) \text {; pebbles are } \\
<10 \mathrm{~mm} \text { in diameter. }\end{array}$ \\
\hline 580 & Gravelly sand (gS); coarse sand to granules; moderately sorted; subangular; light yellowish brown (2.5Y 6/4). \\
\hline 600 & $\begin{array}{l}\text { Gravelly silty sand (gmS); coarse sand to granules with some silt; moderately sorted; subangular; dark yellowish brown } \\
\text { (10YR 4/4). }\end{array}$ \\
\hline 620 & $\begin{array}{l}\text { Gravelly silty sand (gmS); coarse sand to granules with some silt; moderately sorted; subangular; dark yellowish brown } \\
\text { (10YR 4/4). }\end{array}$ \\
\hline 630 & $\begin{array}{l}\text { Gravelly silty sand (gmS); coarse sand to granules with occasional silt; moderately sorted; subangular; light yellowish } \\
\text { brown }(2.5 \mathrm{Y} 6 / 4) \text {. }\end{array}$ \\
\hline 640 & Gravelly sand (gS); coarse sand to granules; moderately sorted; subangular; light yellowish brown (2.5Y 6/4). \\
\hline 650 & $\begin{array}{l}\text { Gravelly silty sand (gmS); coarse sand to granules with occasional silt; moderately sorted; subangular; light olive brown } \\
\text { (2.5Y 5/4). }\end{array}$ \\
\hline 670 & Gravelly silty sand (gmS); coarse sand to granules with silt; moderately sorted; subangular; light olive brown (2.5Y 5/4). \\
\hline 680 & Gravelly silty sand (gmS); coarse sand to granules with silt; moderately sorted; subangular; light olive brown (2.5Y 5/4). \\
\hline 690 & $\begin{array}{l}\text { Gravelly silty sand (gmS); coarse sand to pebbles with silt; moderately sorted; subangular; light olive brown }(2.5 \mathrm{Y} 5 / 4) \text {; } \\
\text { pebbles are }<10 \mathrm{~mm} \text { in diameter. }\end{array}$ \\
\hline 700 & $\begin{array}{l}\text { Gravelly silty sand (gmS); coarse sand to pebbles with silt; moderately sorted; subangular; light yellowish brown } \\
(2.5 \mathrm{Y} 6 / 4) \text {; pebbles are }<10 \mathrm{~mm} \text { in diameter. }\end{array}$ \\
\hline 710 & $\begin{array}{l}\text { Gravelly silty sand (gmS); coarse sand to pebbles with occasional silt; moderately sorted; subangular; light olive brown } \\
(2.5 \mathrm{Y} 5 / 4) \text {; pebbles are }<10 \mathrm{~mm} \text { in diameter. }\end{array}$ \\
\hline 720 & $\begin{array}{l}\text { Gravelly silty sand (gmS); coarse sand to granules with some silt; moderately sorted; subangular; light olive brown } \\
(2.5 \mathrm{Y} 5 / 4) \text {. }\end{array}$ \\
\hline 730 & $\begin{array}{l}\text { Gravelly silty sand (gmS); very coarse sand to pebbles with silt; moderately sorted; angular to subangular; light yellowish } \\
\text { brown }(2.5 \mathrm{Y} 6 / 4) \text {; pebbles are }<10 \mathrm{~mm} \text { in diameter. }\end{array}$ \\
\hline 740 & $\begin{array}{l}\text { Gravelly silty sand (gmS); coarse sand to granules with silt; moderately sorted; subangular; light yellowish brown } \\
(2.5 \mathrm{Y} 6 / 4) \text {. }\end{array}$ \\
\hline
\end{tabular}


Table 5. Lithologic log from shaker drill cuttings (250- $\mu$ m screen opening) from multiple-well monitoring site RCNE (1N/6W-26A1-3), San Bernardino County, California.-Continued

[Abbreviations: ft, feet; mm, millimeter; <, less than; $\mu \mathrm{m}$, micrometer]

\begin{tabular}{|c|c|}
\hline Depth (ft) & Description \\
\hline 750 & $\begin{array}{l}\text { Gravelly silty sand (gmS); coarse sand to pebbles with silt; moderately sorted; angular to subangular; light yellowish } \\
\text { brown }(2.5 \mathrm{Y} 6 / 4) \text {; pebbles are }<10 \mathrm{~mm} \text { in diameter. }\end{array}$ \\
\hline 760 & $\begin{array}{l}\text { Gravelly silty sand (gmS); coarse sand to granules with silt; moderately sorted; subangular; light yellowish brown } \\
(2.5 \mathrm{Y} 6 / 4) \text {. }\end{array}$ \\
\hline 770 & $\begin{array}{l}\text { Gravelly silty sand (gmS); coarse sand to granules with silt; moderately sorted; subangular; light yellowish brown } \\
\quad(2.5 \mathrm{Y} 6 / 4) \text {. }\end{array}$ \\
\hline 800 & $\begin{array}{l}\text { Gravelly silty sand (gmS); coarse sand to pebbles with silt; moderately sorted; subangular; light olive brown (2.5Y 5/4); } \\
\text { pebbles are }<10 \mathrm{~mm} \text { in diameter. }\end{array}$ \\
\hline 810 & Gravelly silty sand (gmS); coarse sand to granules with silt; moderately sorted; subangular; light olive brown (2.5Y 5/4). \\
\hline 820 & Gravelly silty sand (gmS); coarse sand to granules with silt; moderately sorted; subangular; light olive brown (2.5Y 5/4). \\
\hline 830 & $\begin{array}{l}\text { Gravelly silty clayey sand (gmS); coarse sand to granules with silt and clay; moderately sorted; subangular; light olive } \\
\text { brown }(2.5 \mathrm{Y} 5 / 4) \text {. }\end{array}$ \\
\hline
\end{tabular}


Table 6. Lithologic log from sieved drill cuttings (125- $\mu \mathrm{m}$ screen opening) from multiple-well monitoring site RCSW (1N/6W-26K2-3), San Bernardino County, California.

[Abbreviations: ft, feet; mm, millimeter; <, less than; $\mu \mathrm{m}$, micrometer]

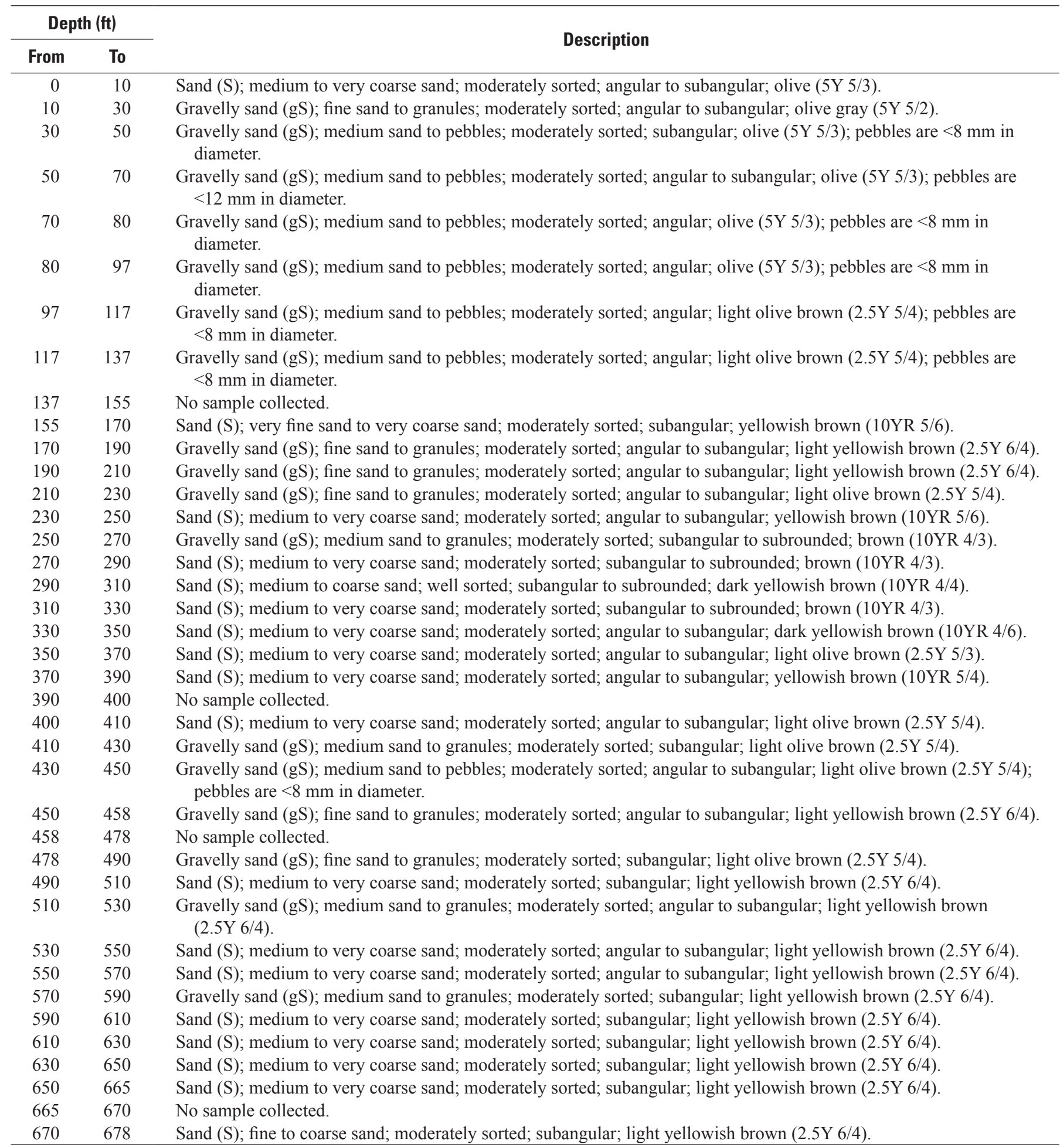


Table 7. Lithologic log from shaker drill cuttings (250- $\mu \mathrm{m}$ screen opening) from multiple-well monitoring site RCSW (1N/6W-26K2-3), San Bernardino County, California.

[Abbreviations: ft, feet; mm, millimeter; <, less than; $\mu \mathrm{m}$, micrometer]

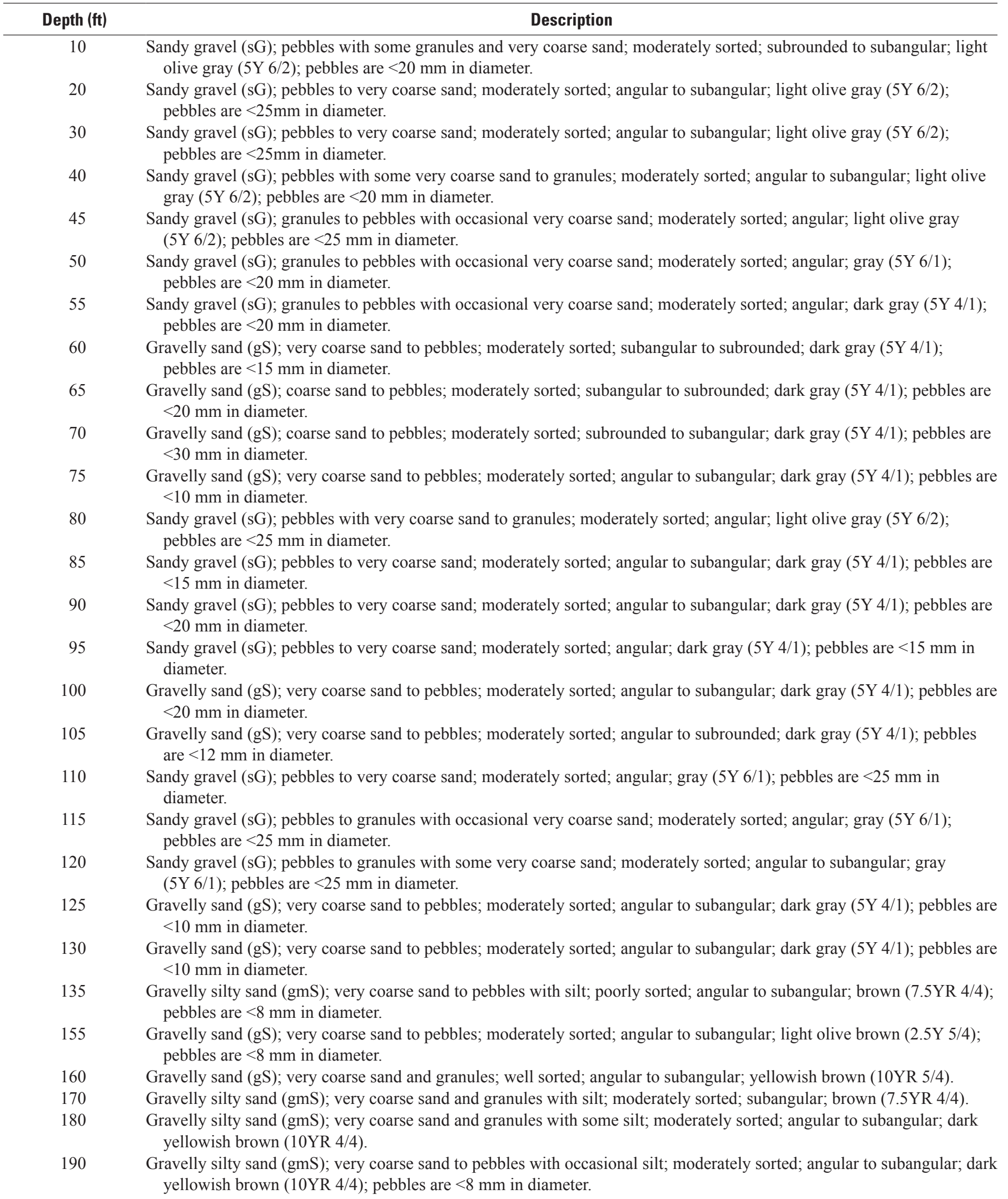


Table 7. Lithologic log from shaker drill cuttings (250- $\mu \mathrm{m}$ screen opening) from multiple-well monitoring site RCSW (1N/6W-26K2-3), San Bernardino County, California.-Continued

[Abbreviations: $\mathrm{ft}$, feet; $\mathrm{mm}$, millimeter; $<$, less than; $\mu \mathrm{m}$, micrometer]

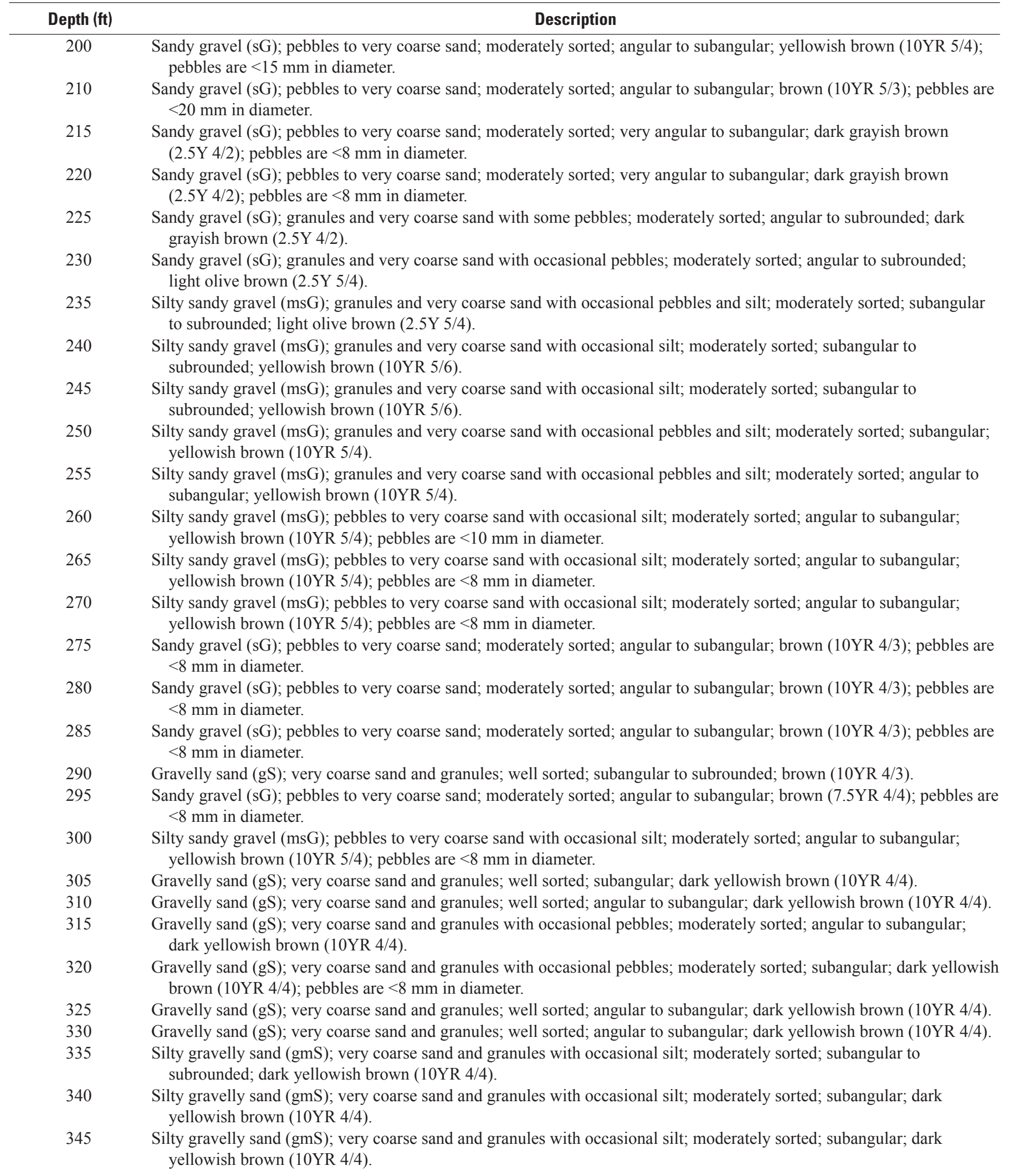


Table 7. Lithologic log from shaker drill cuttings (250- $\mu$ m screen opening) from multiple-well monitoring site RCSW (1N/6W-26K2-3), San Bernardino County, California.-Continued

[Abbreviations: ft, feet; mm, millimeter; <, less than; $\mu \mathrm{m}$, micrometer]

\begin{tabular}{|c|c|}
\hline Depth (ft) & Description \\
\hline 350 & $\begin{array}{l}\text { Silty gravelly sand (gmS); very coarse sand and granules with occasional silt; moderately sorted; subangular; dark } \\
\text { yellowish brown (10YR 4/4). }\end{array}$ \\
\hline 355 & Gravelly sand (gS); very coarse sand and granules; well sorted; subangular; dark yellowish brown (10YR 4/4). \\
\hline 360 & Gravelly sand (gS); very coarse sand and granules; well sorted; subangular; dark yellowish brown (10YR 4/4). \\
\hline 370 & Gravelly sand (gS); very coarse sand and granules; well sorted; subangular; dark yellowish brown (10YR 4/4). \\
\hline 375 & Gravelly sand (gS); very coarse sand and granules; well sorted; subangular; dark yellowish brown (10YR 4/4). \\
\hline 390 & Gravelly sand (gS); very coarse sand and granules; well sorted; subangular; dark yellowish brown (10YR 4/4). \\
\hline 410 & Gravelly sand (gS); very coarse sand and granules; well sorted; subangular; dark yellowish brown (10YR 4/4). \\
\hline 415 & $\begin{array}{l}\text { Gravelly sand (gS); very coarse sand and granules with occasional pebbles; moderately sorted; subangular; dark yellowish } \\
\text { brown (10YR 4/4); pebbles are }<10 \mathrm{~mm} \text { in diameter. }\end{array}$ \\
\hline 420 & $\begin{array}{l}\text { Gravelly sand (gS); very coarse sand and granules with occasional pebbles; moderately sorted; subangular; dark yellowish } \\
\text { brown (10YR 4/4); pebbles are }<10 \mathrm{~mm} \text { in diameter. }\end{array}$ \\
\hline 440 & Sandy gravel (sG); granules and very coarse sand; well sorted; subangular; dark yellowish brown (10YR 4/4). \\
\hline 445 & $\begin{array}{l}\text { Gravelly sand (gS); very coarse sand and granules with occasional pebbles; moderately sorted; angular to subangular; } \\
\text { olive brown }(2.5 \mathrm{Y} 4 / 3) \text {. }\end{array}$ \\
\hline 450 & $\begin{array}{l}\text { Gravelly sand (gS); very coarse sand to pebbles; moderately sorted; subangular; olive brown (2.5Y 4/3); pebbles are } \\
\quad<10 \mathrm{~mm} \text { in diameter. }\end{array}$ \\
\hline 475 & Gravelly sand (gS); very coarse sand and granules; well sorted; subangular; dark yellowish brown (10YR 4/4). \\
\hline 480 & $\begin{array}{l}\text { Gravelly silty sand (gmS); very coarse sand and granules with occasional silt and pebbles; moderately sorted; subangular } \\
\text { to subrounded; light olive brown }(2.5 \mathrm{Y} 5 / 4) \text {. }\end{array}$ \\
\hline 490 & $\begin{array}{l}\text { Gravelly silty sand (gmS); very coarse sand and granules with some silt and pebbles; moderately sorted; subangular to } \\
\text { subrounded; yellowish brown (10YR 5/4). }\end{array}$ \\
\hline 510 & $\begin{array}{l}\text { Silty sandy gravel (msG); pebbles to very coarse sand with some silt; moderately sorted; subangular to subrounded; light } \\
\text { olive brown }(2.5 \mathrm{Y} 5 / 4) \text {. }\end{array}$ \\
\hline 520 & $\begin{array}{l}\text { Gravelly silty sand (gmS); very coarse sand and granules with some silt; moderately sorted; subrounded; light olive brown } \\
(2.5 \mathrm{Y} 5 / 4) \text {. }\end{array}$ \\
\hline 530 & $\begin{array}{l}\text { Gravelly silty sand (gmS); very coarse sand and granules with some silt; moderately sorted; subangular to subrounded; } \\
\text { light olive brown }(2.5 \mathrm{Y} 5 / 4) \text {. }\end{array}$ \\
\hline 540 & $\begin{array}{l}\text { Silty sandy gravel (msG); pebbles to very coarse sand with occasional silt; moderately sorted; subrounded; light olive } \\
\text { brown }(2.5 \mathrm{Y} 5 / 4) \text {. }\end{array}$ \\
\hline 545 & $\begin{array}{l}\text { Silty sandy gravel (msG); pebbles to very coarse sand with some silt; moderately sorted; subrounded; yellowish brown } \\
\text { (10YR 5/4); pebbles are }<10 \mathrm{~mm} \text { in diameter. }\end{array}$ \\
\hline 550 & $\begin{array}{l}\text { Silty sandy gravel (msG); pebbles to very coarse sand with some silt; moderately sorted; subangular to subrounded; } \\
\text { yellowish brown (10YR 5/4); pebbles are }<10 \mathrm{~mm} \text { in diameter. }\end{array}$ \\
\hline 555 & $\begin{array}{l}\text { Silty sandy gravel (msG); pebbles to very coarse sand with some silt; moderately sorted; subangular to subrounded; } \\
\text { yellowish brown (10YR 5/4); pebbles are }<10 \mathrm{~mm} \text { in diameter. }\end{array}$ \\
\hline 560 & $\begin{array}{l}\text { Silty sandy gravel ( } \mathrm{msG}) \text {; pebbles to very coarse sand with some silt; moderately sorted; subangular to subrounded; } \\
\text { yellowish brown (10YR 5/4); pebbles are }<10 \mathrm{~mm} \text { in diameter. }\end{array}$ \\
\hline 570 & $\begin{array}{l}\text { Silty sandy gravel (msG); pebbles to very coarse sand with some silt; moderately sorted; subangular to subrounded; } \\
\text { yellowish brown (10YR 5/4); pebbles are }<10 \mathrm{~mm} \text { in diameter. }\end{array}$ \\
\hline 575 & $\begin{array}{l}\text { Sandy gravel (sG); pebbles to very coarse sand; moderately sorted; subangular; yellowish brown (10YR 5/4); pebbles are } \\
\quad<10 \mathrm{~mm} \text { in diameter. }\end{array}$ \\
\hline
\end{tabular}


Table 7. Lithologic log from shaker drill cuttings (250- $\mu \mathrm{m}$ screen opening) from multiple-well monitoring site RCSW (1N/6W-26K2-3), San Bernardino County, California.-Continued

[Abbreviations: $\mathrm{ft}$, feet; $\mathrm{mm}$, millimeter; $<$, less than; $\mu \mathrm{m}$, micrometer]

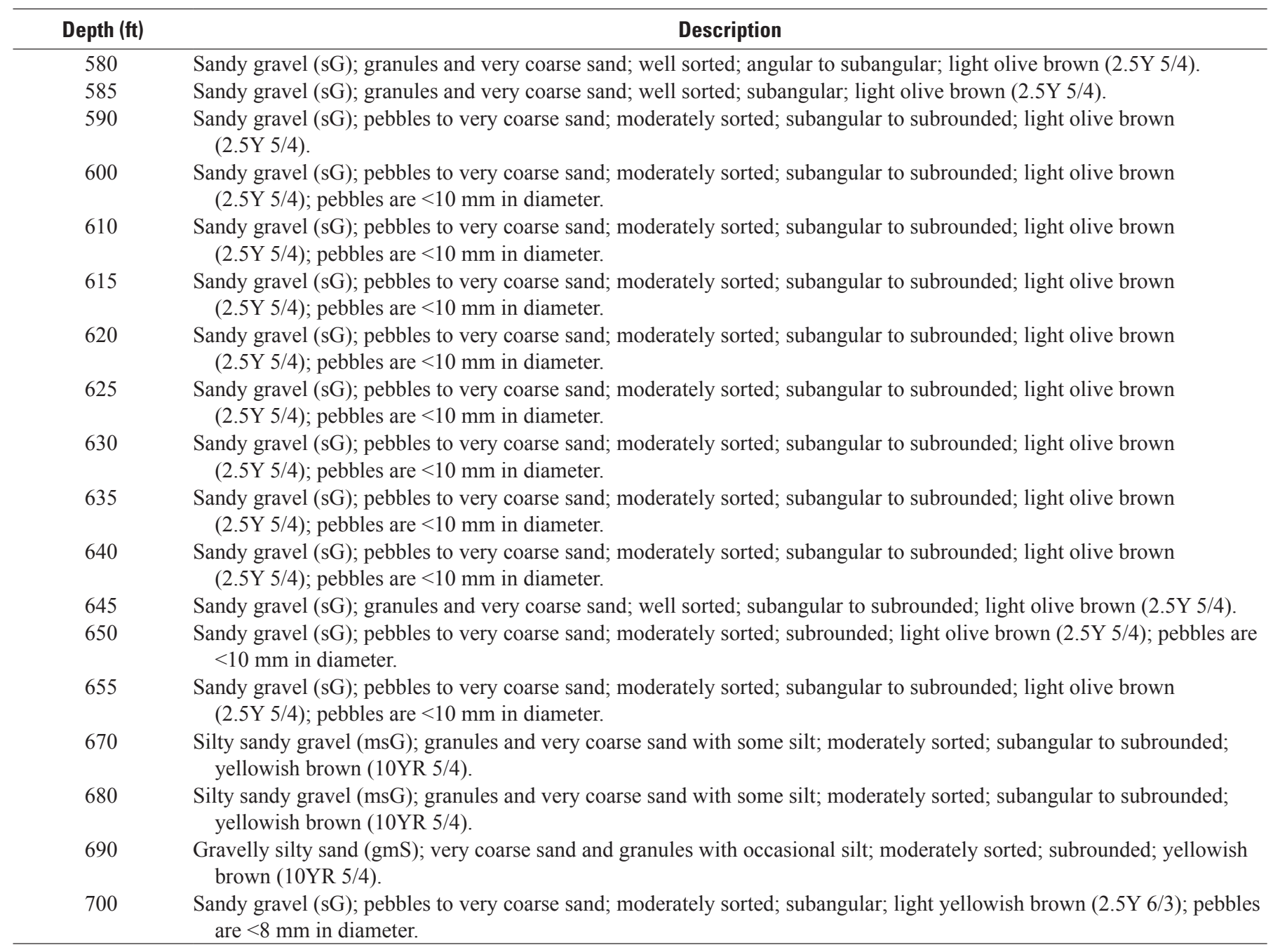


Table 8. Lithologic log from sieved drill cuttings (125- $\mu \mathrm{m}$ screen opening) from multiple-well monitoring site CRCR (1S/5W-03A3-8), San Bernardino County, California.

[Abbreviations: ft, feet; $\mu \mathrm{m}$, micrometer]

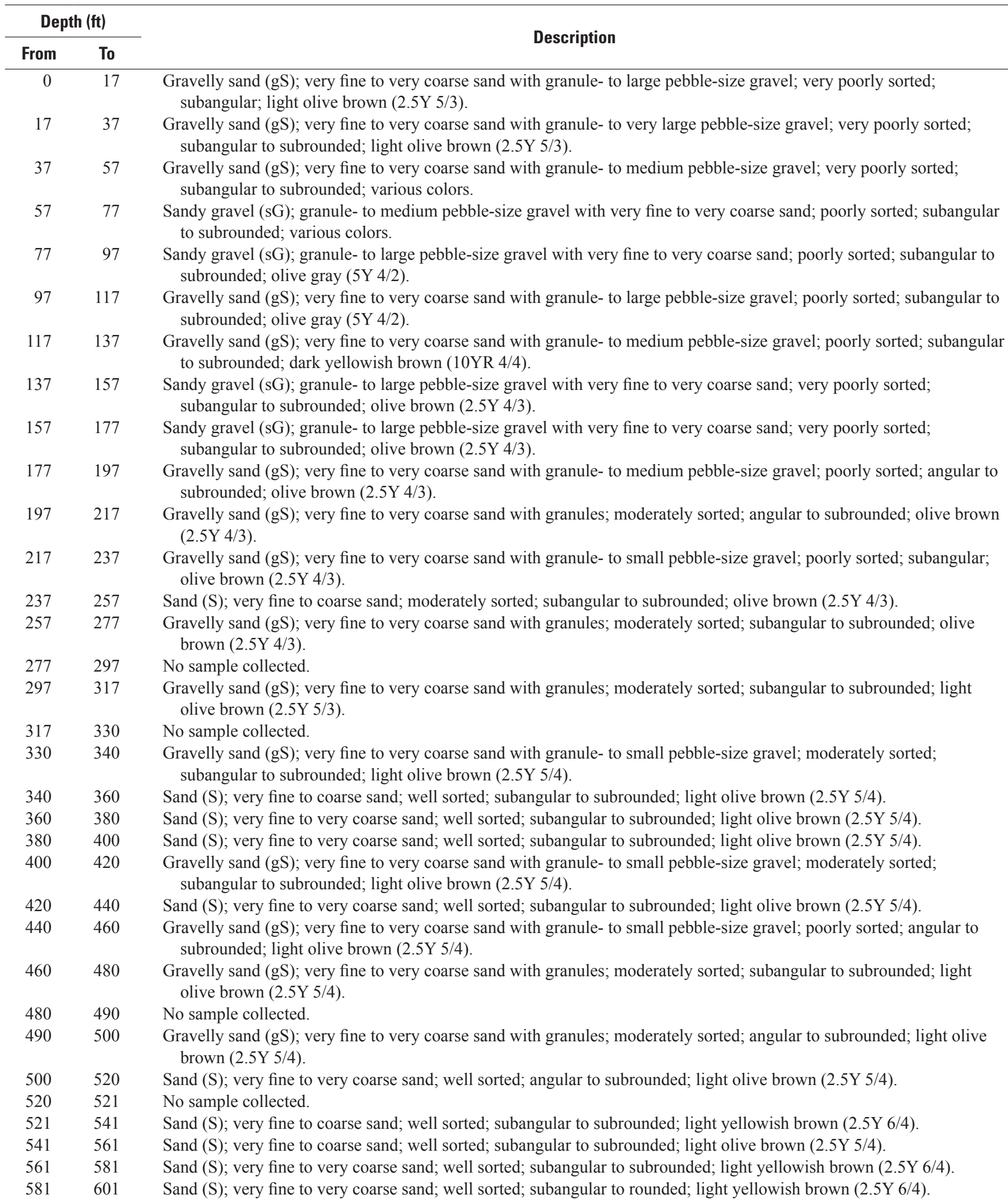


Table 8. Lithologic log from sieved drill cuttings (125- $\mu \mathrm{m}$ screen opening) from multiple-well monitoring site CRCR (1S/5W-03A3-8), San Bernardino County, California.-Continued

[Abbreviations: $\mathrm{ft}$, feet; $\mu \mathrm{m}$, micrometer]

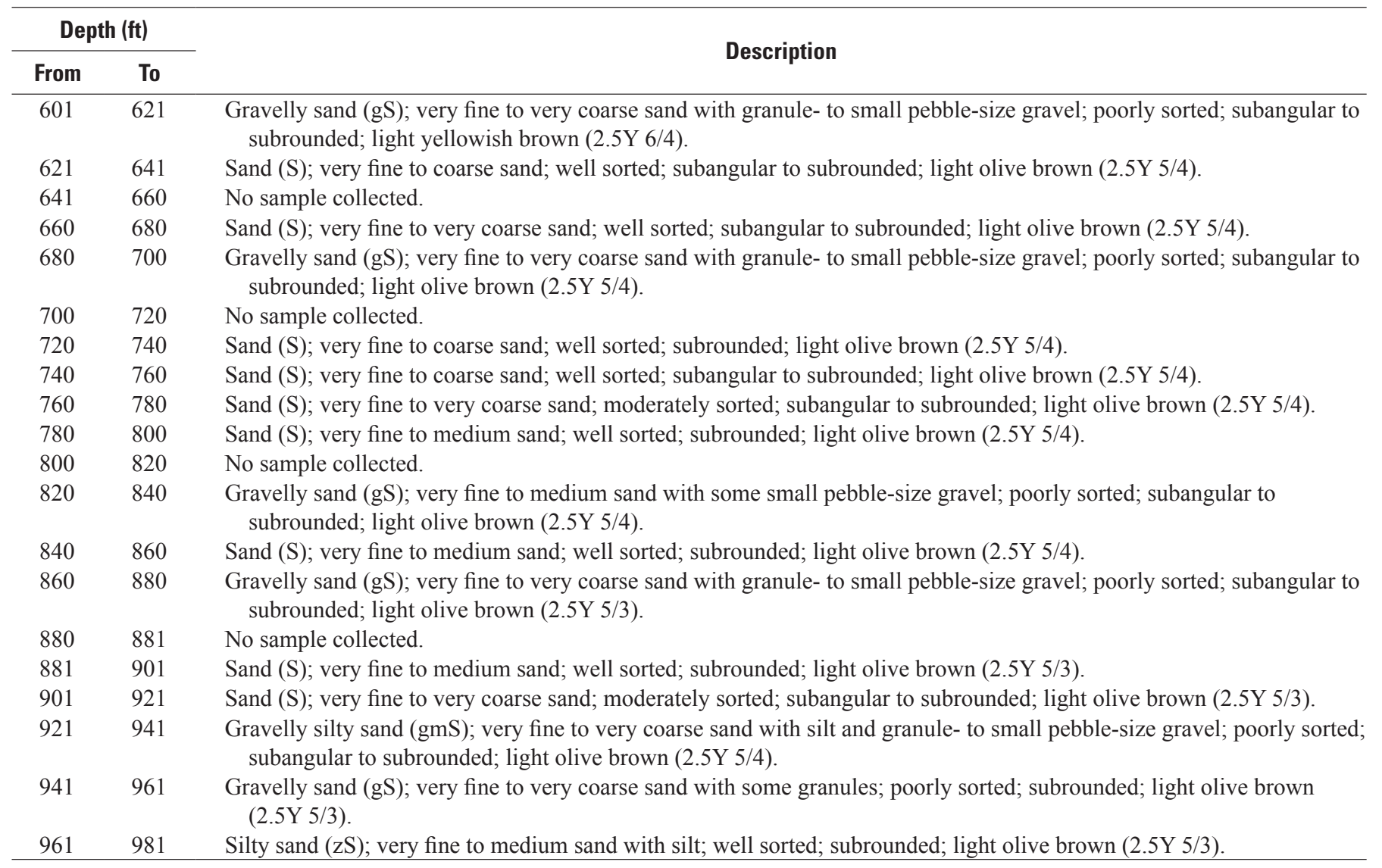


Table 9. Lithologic log from shaker drill cuttings (250- $\mu \mathrm{m}$ screen opening) from multiple-well monitoring site CRCR (1S/5W-03A3-8), San Bernardino County, California.

[Abbreviations: ft, feet; $\mu \mathrm{m}$, micrometer]

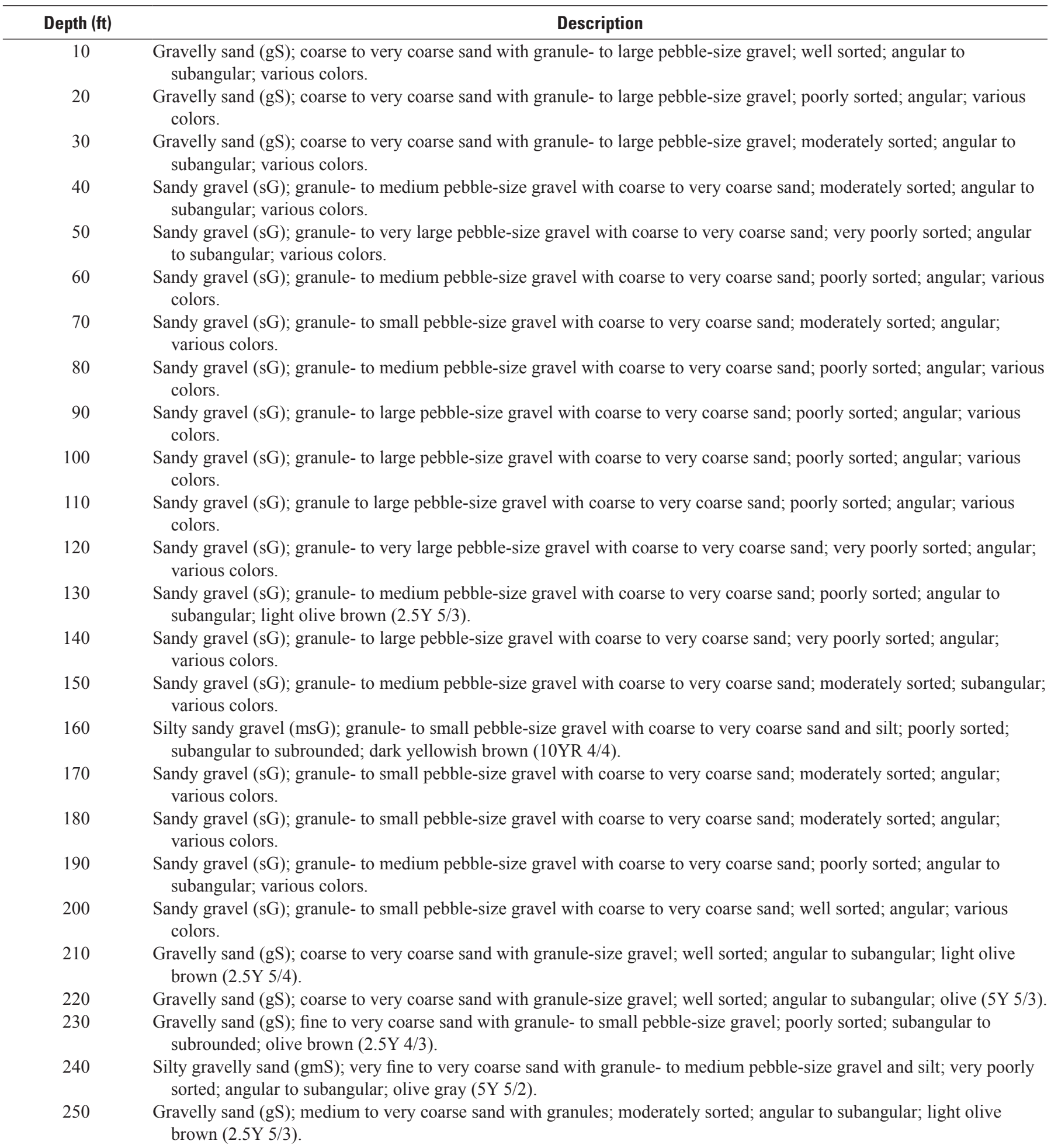


Table 9. Lithologic log from shaker drill cuttings (250- $\mu \mathrm{m}$ screen opening) from multiple-well monitoring site CRCR (1S/5W-03A3-8), San Bernardino County, California.-Continued

[Abbreviations: $\mathrm{ft}$, feet; $\mu \mathrm{m}$, micrometer]

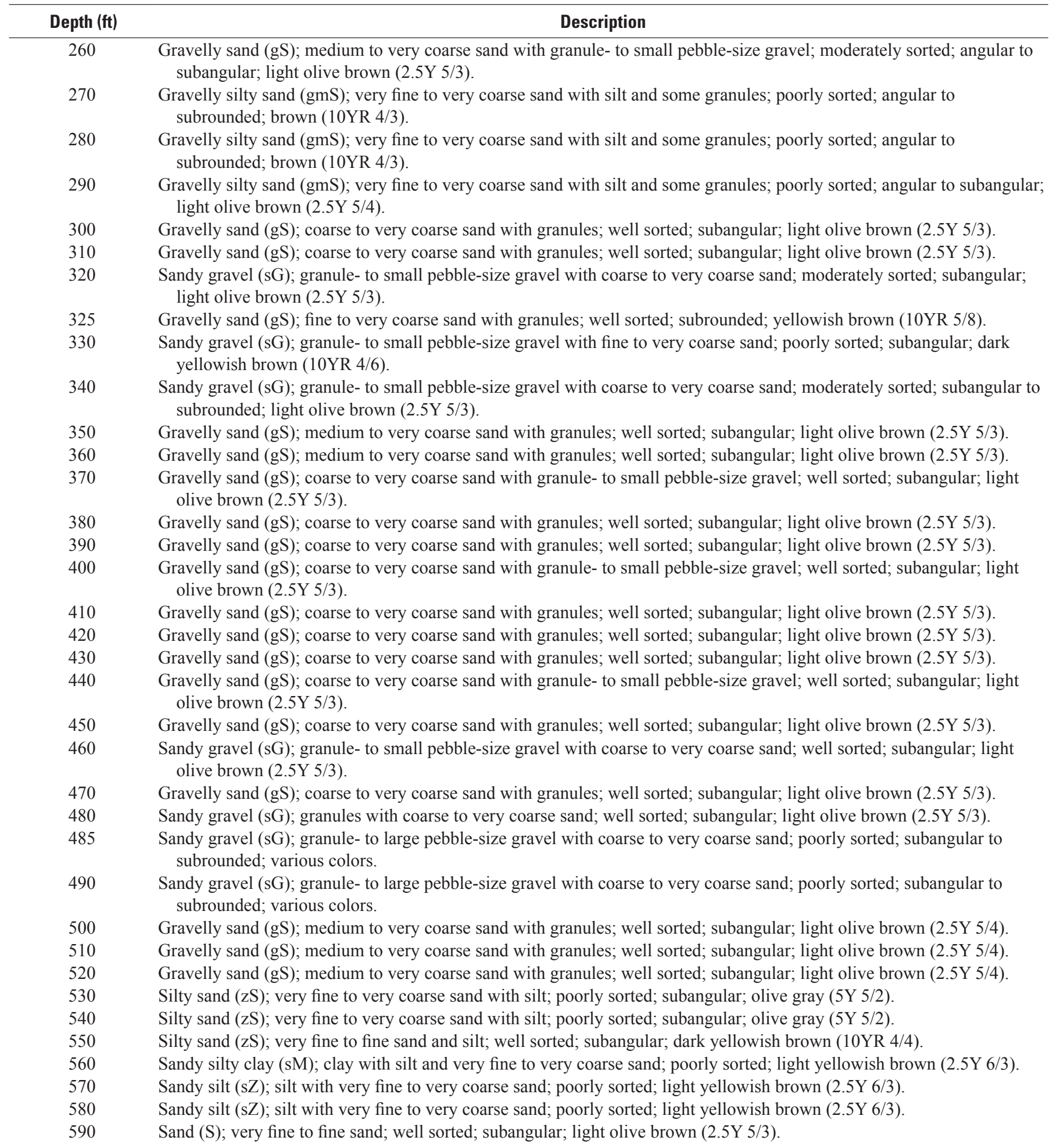


Table 9. Lithologic log from shaker drill cuttings (250- $\mu \mathrm{m}$ screen opening) from multiple-well monitoring site CRCR (1S/5W-03A3-8), San Bernardino County, California.-Continued

[Abbreviations: ft, feet; $\mu \mathrm{m}$, micrometer]

\begin{tabular}{|c|c|}
\hline Depth (ft) & Description \\
\hline 600 & $\begin{array}{l}\text { Sand (S); very fine to fine sand with some medium to very coarse sand; moderately sorted; subangular; light olive brown } \\
(2.5 \mathrm{Y} 5 / 3) \text {. }\end{array}$ \\
\hline 610 & Silty sand (zS); very fine to very coarse sand with silt; poorly sorted; subangular; light olive brown (2.5Y 5/3). \\
\hline 620 & Silty sand (zS); very fine to very coarse sand with silt; poorly sorted; subangular; light olive brown (2.5Y 5/3). \\
\hline 630 & Silty sand (zS); very fine to very coarse sand with silt; poorly sorted; subangular; light olive brown (2.5Y 5/3). \\
\hline 640 & Silty sand (zS); very fine to very coarse sand with silt; poorly sorted; subangular; light olive brown (2.5Y 5/3). \\
\hline 651 & Sand (S); very fine to medium sand; well sorted; subangular; various colors. \\
\hline 660 & $\begin{array}{l}\text { Gravelly sand (gS); very fine to very coarse sand with granules; poorly sorted; subangular to subrounded; light olive } \\
\text { brown }(2.5 \mathrm{Y} 5 / 3) \text {. }\end{array}$ \\
\hline 670 & Gravelly sand (gS); fine to very coarse sand with granules; poorly sorted; subangular; light olive brown (2.5Y 5/3). \\
\hline 680 & $\begin{array}{l}\text { Gravelly sand }(\mathrm{gS}) \text {; medium to very coarse sand with granules; moderately sorted; angular to subangular; light olive } \\
\text { brown }(2.5 \mathrm{Y} 5 / 3) \text {. }\end{array}$ \\
\hline 690 & $\begin{array}{l}\text { Gravelly sand (gS); medium to very coarse sand with granule- to small pebble-size gravel; moderately sorted; angular to } \\
\text { subangular; light olive brown }(2.5 \mathrm{Y} 5 / 3) \text {. }\end{array}$ \\
\hline 700 & Sandy silt (sZ); silt with very fine to very coarse sand; poorly sorted; brown (10YR 4/3). \\
\hline 705 & $\begin{array}{l}\text { Gravelly sand }(\mathrm{gS}) \text {; very fine to very coarse sand with granule- to small pebble-size gravel; poorly sorted; subangular; } \\
\text { brown }(10 \mathrm{YR} 5 / 3) \text {. }\end{array}$ \\
\hline 710 & Sand (S); very fine to fine sand; well sorted; subangular; light olive brown (2.5Y 5/4). \\
\hline 720 & Silty sand (zS); very fine to very coarse sand with silt; poorly sorted; subangular; light olive brown (2.5Y 5/3). \\
\hline 730 & Gravelly sand (gS); medium to very coarse sand with granules; well sorted; subangular; light olive brown (2.5Y 5/4). \\
\hline 740 & $\begin{array}{l}\text { Gravelly silty sand (gmS); medium to very coarse sand with silt and granules; poorly sorted; subangular; light olive } \\
\text { brown }(2.5 \mathrm{Y} 5 / 4) \text {. }\end{array}$ \\
\hline 750 & $\begin{array}{l}\text { Gravelly silty sand (gmS); medium to very coarse sand with silt and granules; poorly sorted; subrounded; light olive } \\
\text { brown }(2.5 \mathrm{Y} 5 / 4) \text {. }\end{array}$ \\
\hline 760 & Silty sand (zS); medium to very coarse sand with silt; moderately sorted; subrounded; light olive brown (2.5Y 5/3). \\
\hline 770 & Gravelly sand (gS); medium to very coarse sand with granules; well sorted; subrounded; light olive brown (2.5Y 5/4). \\
\hline 780 & $\begin{array}{l}\text { Gravelly sand (gS); very fine to very coarse sand with granules; poorly sorted; subrounded; light yellowish brown } \\
(2.5 \mathrm{Y} 6 / 4) \text {. }\end{array}$ \\
\hline 790 & Silty sand (zS); very fine to very coarse sand with silt; poorly sorted; subrounded; light yellowish brown (2.5Y 6/4). \\
\hline 800 & $\begin{array}{l}\text { Gravelly silty sand (gmS); very fine to very coarse sand with silt and granules; poorly sorted; subrounded; light olive } \\
\text { brown }(2.5 \mathrm{Y} 5 / 4) \text {. }\end{array}$ \\
\hline 805 & Gravel $(G)$; small to large pebble-size gravel; well sorted; angular; various colors. \\
\hline 810 & Gravel $(G)$; granule- to very large pebble-size gravel; moderately sorted; angular to rounded; various colors. \\
\hline 820 & Silty sand (zS); very fine to very coarse sand with silt; poorly sorted; subangular; light olive brown (2.5Y 5/3). \\
\hline 830 & $\begin{array}{l}\text { Gravelly silty sand (gmS); fine to very coarse sand with silt and granules; poorly sorted; subangular to subrounded; light } \\
\text { olive brown }(2.5 \mathrm{Y} 5 / 3) \text {. }\end{array}$ \\
\hline 840 & $\begin{array}{l}\text { Gravelly silty sand (gmS); very fine to very coarse sand with silt and granules; poorly sorted; subangular to subrounded; } \\
\text { light olive brown }(2.5 \mathrm{Y} 5 / 3) \text {. }\end{array}$ \\
\hline 850 & $\begin{array}{l}\text { Silty sand (zS); medium to very coarse sand with silt; moderately sorted; subangular to subrounded; light olive brown } \\
(2.5 \mathrm{Y} 5 / 3) \text {. }\end{array}$ \\
\hline 860 & $\begin{array}{l}\text { Gravelly sand (gS); fine to very coarse sand with granules; moderately sorted; subangular to subrounded; light olive } \\
\text { brown }(2.5 \mathrm{Y} 5 / 3) \text {. }\end{array}$ \\
\hline 870 & $\begin{array}{l}\text { Gravelly sand }(\mathrm{gS}) \text {; medium to very coarse sand with granule- to small pebble-size gravel; moderately sorted; subangular } \\
\text { to subrounded; light olive brown }(2.5 \mathrm{Y} 5 / 3) \text {. }\end{array}$ \\
\hline 880 & $\begin{array}{l}\text { Gravelly sand (gS); fine to very coarse sand with granule- to small pebble-size gravel; moderately sorted; subangular to } \\
\text { subrounded; light olive brown }(2.5 \mathrm{Y} 5 / 3) \text {. }\end{array}$ \\
\hline 890 & Silty sand (zS); very fine to fine sand with silt; well sorted; subrounded; light olive brown (2.5Y 5/4). \\
\hline
\end{tabular}


Table 9. Lithologic log from shaker drill cuttings (250- $\mu \mathrm{m}$ screen opening) from multiple-well monitoring site CRCR (1S/5W-03A3-8), San Bernardino County, California.-Continued

[Abbreviations: $\mathrm{ft}$, feet; $\mu \mathrm{m}$, micrometer]

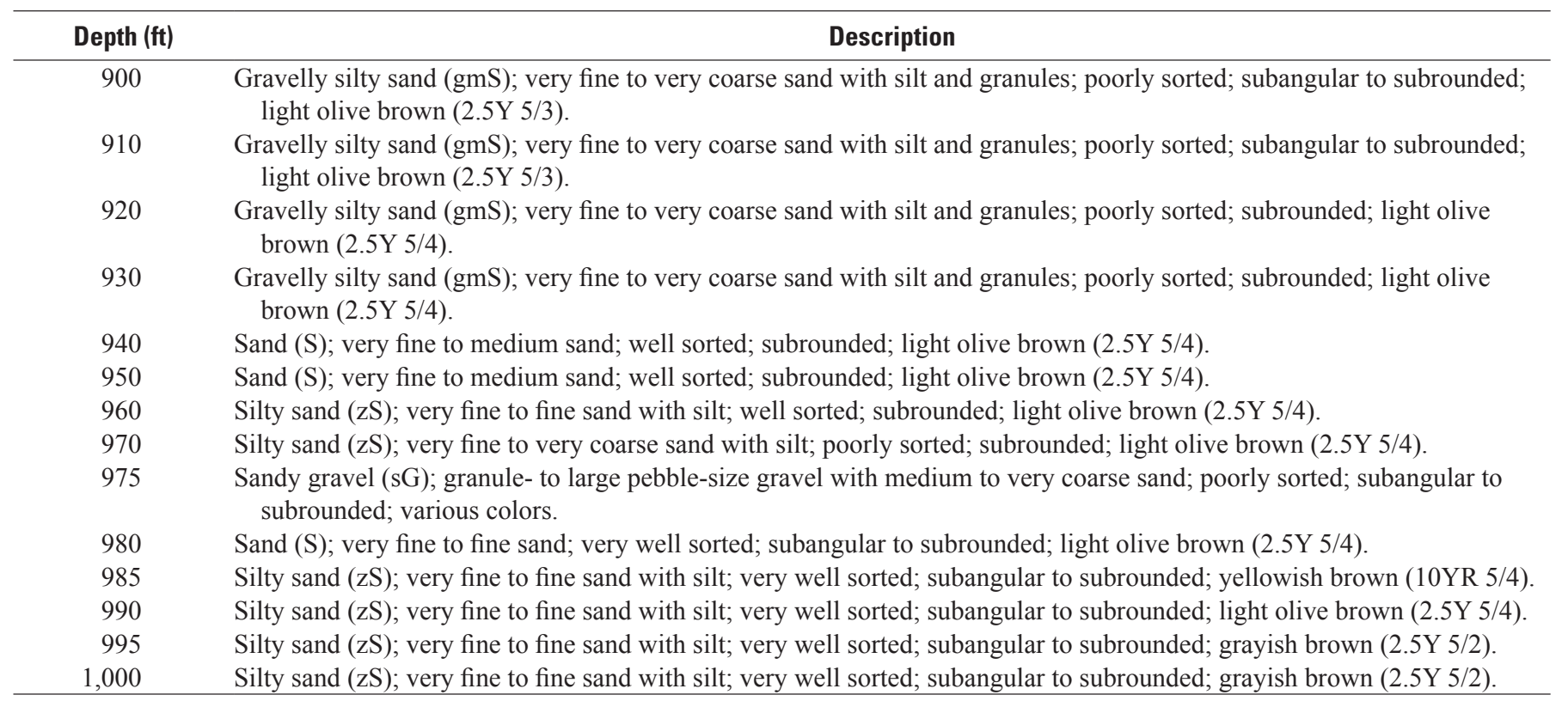


Table 10. Lithologic log from sieved drill cuttings (125- $\mu \mathrm{m}$ screen opening) from multiple-well monitoring site RHSW (1S/5W-13B1-5), San Bernardino County, California.

[Abbreviations: ft, feet; $\mu \mathrm{m}$, micrometer]

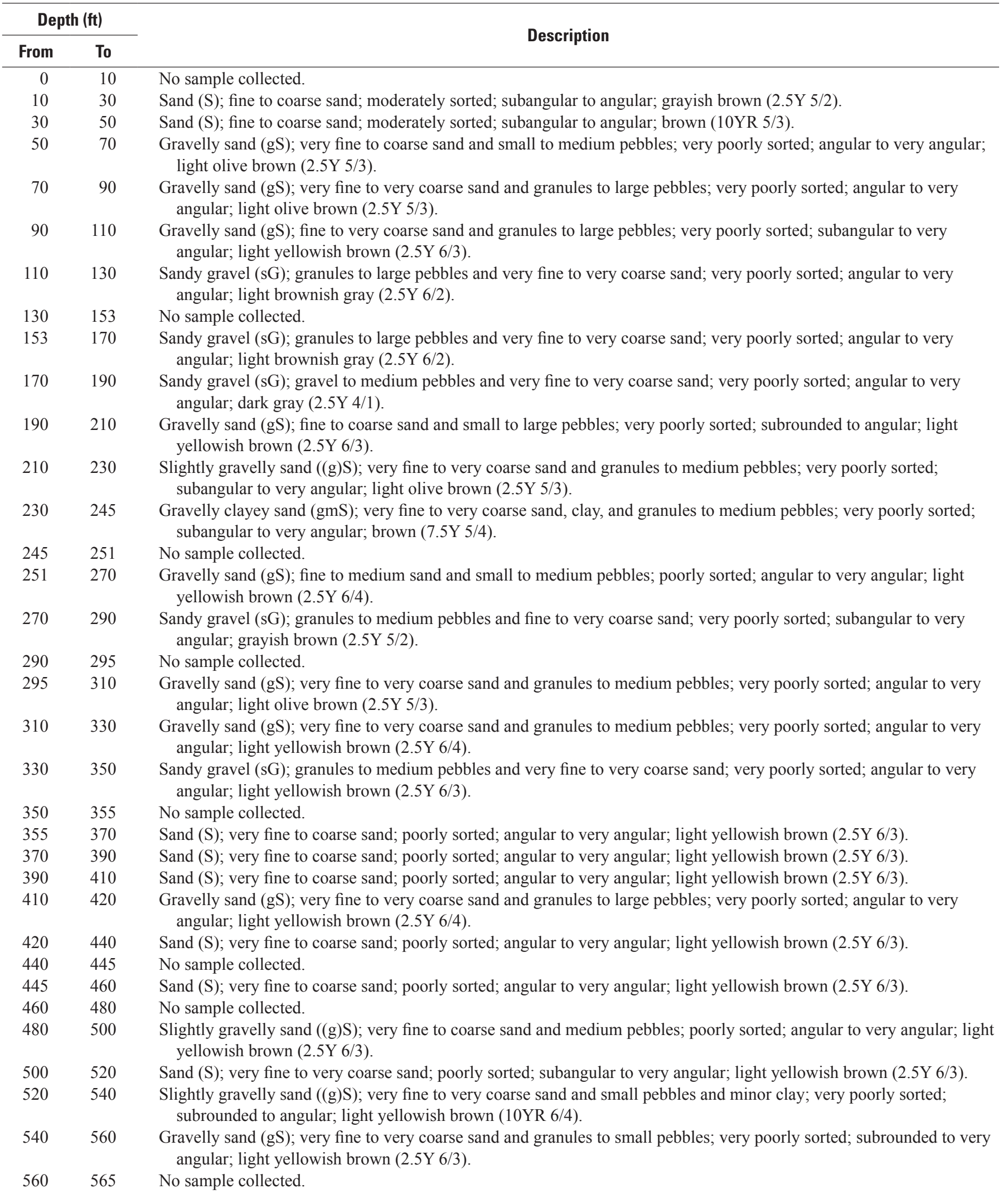


Table 10. Lithologic log from sieved drill cuttings (125- $\mu \mathrm{m}$ screen opening) from multiple-well monitoring site RHSW (1S/5W-13B1-5), San Bernardino County, California.-Continued

[Abbreviations: $\mathrm{ft}$, feet; $\mu \mathrm{m}$, micrometer]

\begin{tabular}{|c|c|c|}
\hline \multicolumn{2}{|c|}{ Depth (ft) } & \multirow[b]{2}{*}{ Description } \\
\hline From & To & \\
\hline 565 & 580 & $\begin{array}{l}\text { Slightly gravelly sand }((\mathrm{g}) \mathrm{S}) \text {; very fine to coarse sand and medium pebbles; poorly sorted; subangular to angular; light } \\
\text { yellowish brown }(2.5 \mathrm{Y} 6 / 3) \text {. }\end{array}$ \\
\hline 580 & 600 & Sand (S); very fine to coarse sand; poorly sorted; angular; light yellowish brown (2.5Y 6/3). \\
\hline 600 & 620 & $\begin{array}{l}\text { Slightly gravelly sand }((\mathrm{g}) \mathrm{S}) \text {; very fine to very coarse sand and granules; very poorly sorted; angular to very angular; } \\
\text { light yellowish brown }(2.5 \mathrm{Y} 6 / 3) \text {. }\end{array}$ \\
\hline 640 & 660 & $\begin{array}{l}\text { Slightly gravelly sand }((\mathrm{g}) \mathrm{S}) \text {; very fine to very coarse sand and small pebbles; very poorly sorted; angular to very } \\
\text { angular; light yellowish brown }(2.5 \mathrm{Y} 6 / 3) \text {. }\end{array}$ \\
\hline 660 & 663 & No sample collected. \\
\hline 663 & 680 & $\begin{array}{l}\text { Slightly gravelly sand }((\mathrm{g}) \mathrm{S}) \text {; very fine to very coarse sand and granules to small pebbles; very poorly sorted; angular to } \\
\text { very angular; light yellowish brown }(2.5 \mathrm{Y} 6 / 3) \text {. }\end{array}$ \\
\hline 720 & 740 & $\begin{array}{l}\text { Silty sand (zS); very fine to very coarse sand and silt; very poorly sorted; subrounded to angular; light yellowish brown } \\
\quad(2.5 \mathrm{Y} 6 / 3) \text {. }\end{array}$ \\
\hline 740 & 760 & $\begin{array}{l}\text { Slightly gravelly sand }((\mathrm{g}) \mathrm{S}) \text {; very fine to very coarse sand and granules; very poorly sorted; subangular to very angular; } \\
\text { light yellowish brown }(2.5 \mathrm{Y} 6 / 3) \text {. }\end{array}$ \\
\hline 760 & 780 & Sand (S); very fine to very coarse sand; poorly sorted; angular to very angular; light yellowish brown (2.5Y 6/3). \\
\hline 780 & 800 & Sand (S); very fine to medium sand; well to moderately sorted; subangular to angular; light yellowish brown (2.5Y 6/4). \\
\hline 800 & 820 & Sand (S); very fine to medium sand; well to moderately sorted; subangular to angular; light yellowish brown (2.5Y 6/4). \\
\hline 820 & 840 & Sand (S); very fine to medium sand; well to moderately sorted; subangular to angular; light yellowish brown (2.5Y 6/4). \\
\hline 840 & 878 & No sample collected. \\
\hline 878 & 898 & $\begin{array}{l}\text { Sand (S); very fine to medium sand and minor silt; moderately sorted; subangular to angular; light olive brown } \\
(2.5 \mathrm{Y} 5 / 3) \text {. }\end{array}$ \\
\hline
\end{tabular}


Table 11. Lithologic log from shaker drill cuttings $(250-\mu \mathrm{m}$ screen opening) from multiple-well monitoring site RHSW (1S/5W-13B1-5), San Bernardino County, California.

[Abbreviations: ft, feet; $\mu \mathrm{m}$, micrometer]

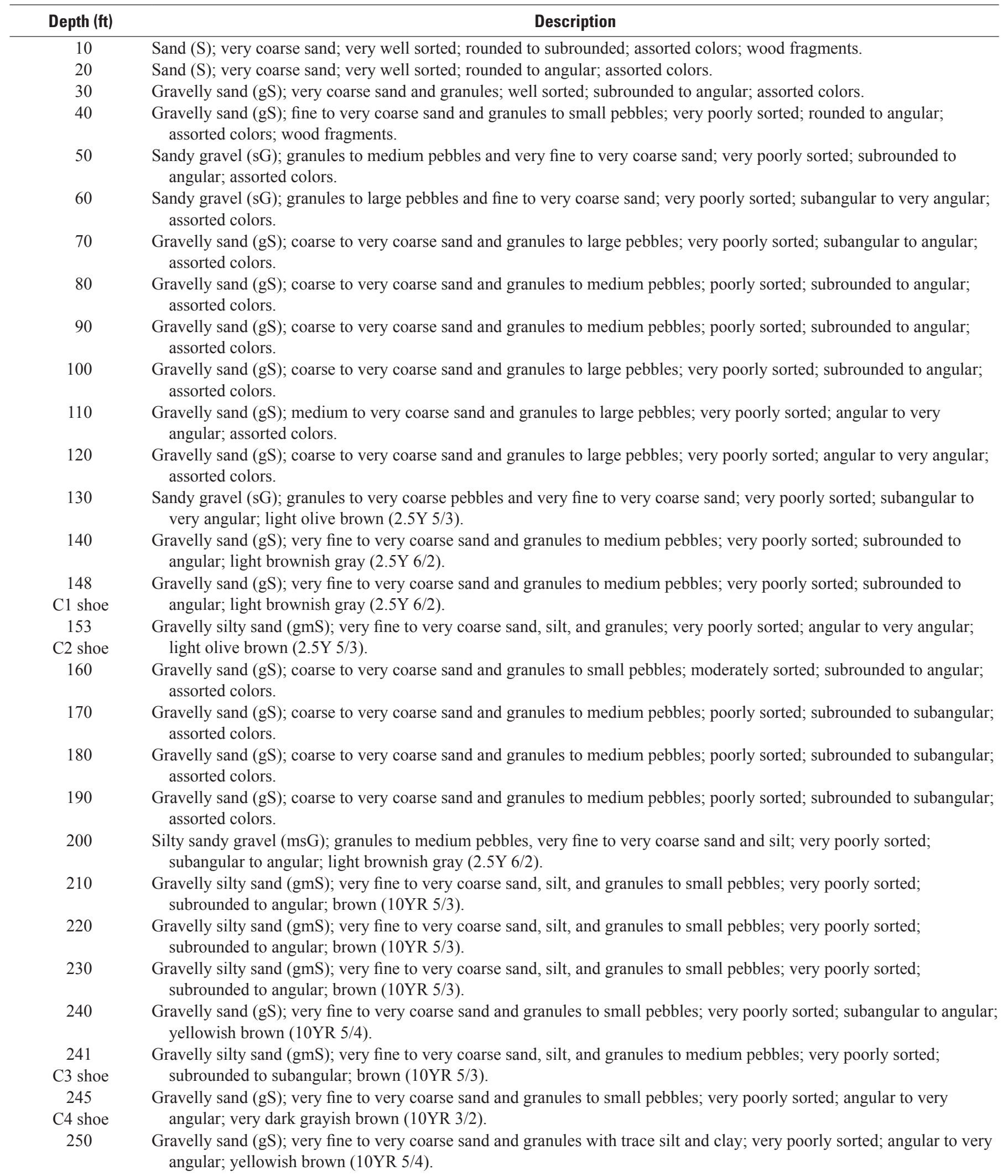


Table 11. Lithologic log from shaker drill cuttings (250- $\mu \mathrm{m}$ screen opening) from multiple-well monitoring site RHSW (1S/5W-13B1-5), San Bernardino County, California.-Continued

[Abbreviations: $\mathrm{ft}$, feet; $\mu \mathrm{m}$, micrometer]

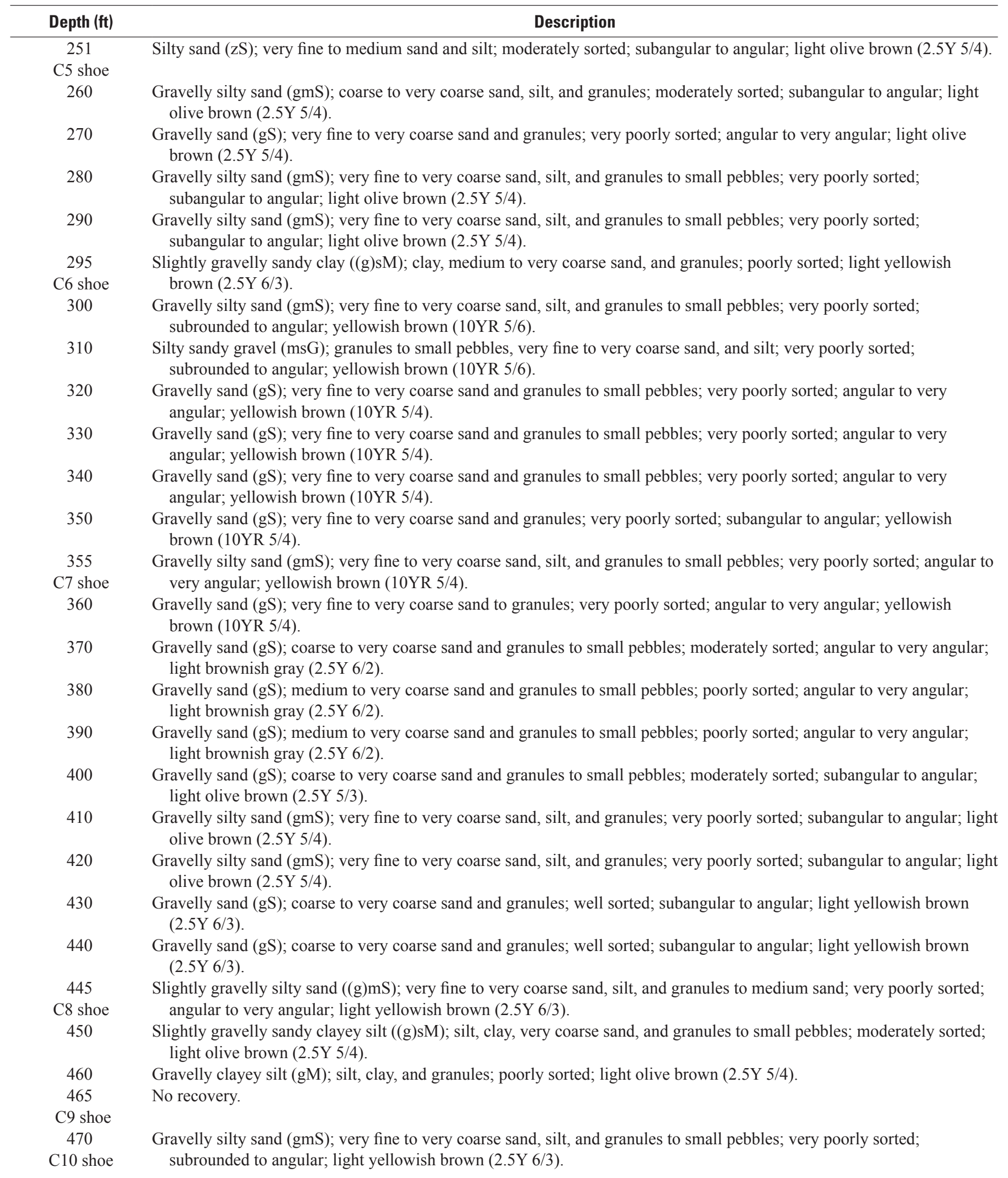


Table 11. Lithologic log from shaker drill cuttings (250- $\mu$ m screen opening) from multiple-well monitoring site RHSW (1S/5W-13B1-5), San Bernardino County, California.-Continued

[Abbreviations: $\mathrm{ft}$, feet; $\mu \mathrm{m}$, micrometer]

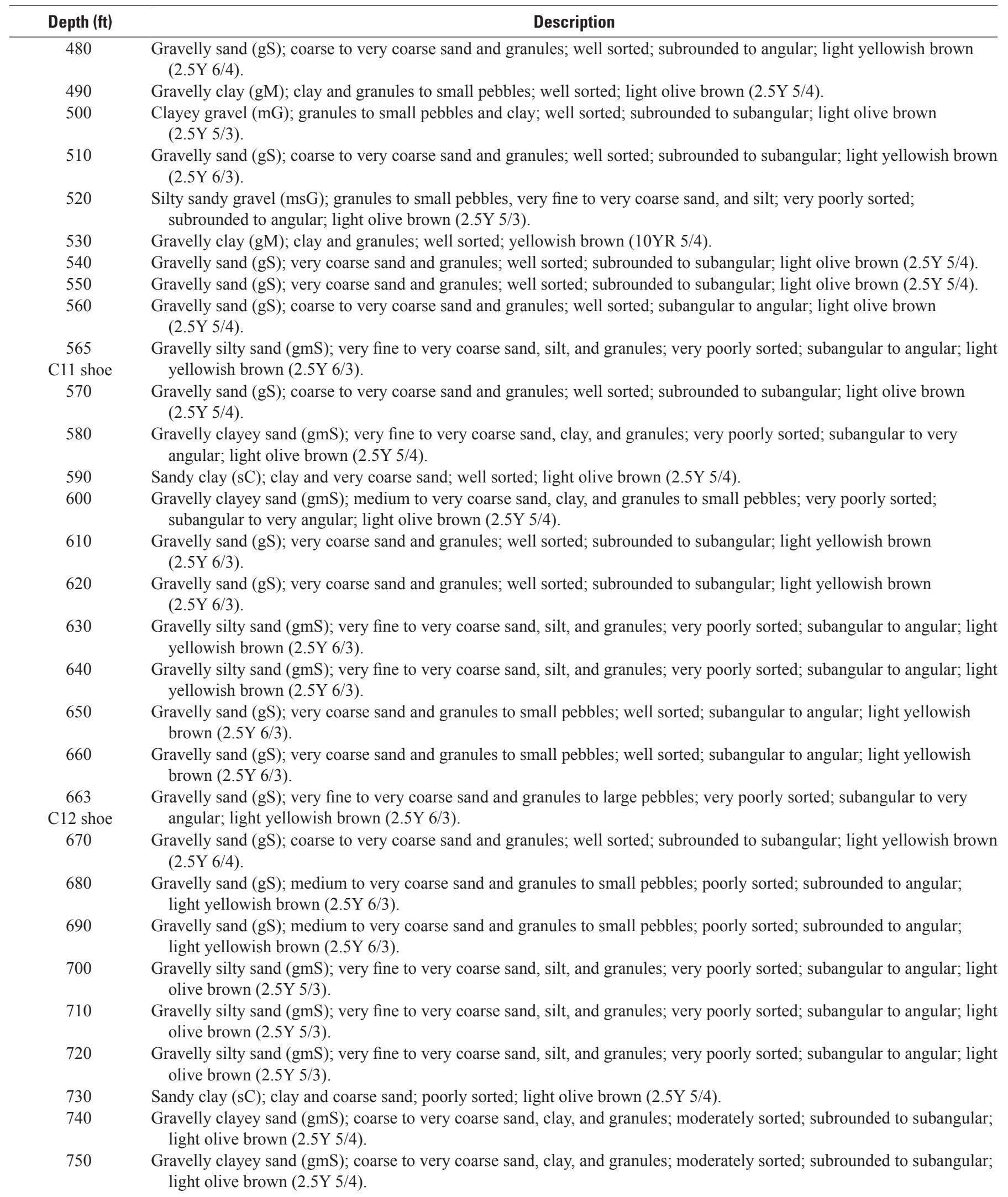


Table 11. Lithologic log from shaker drill cuttings (250- $\mu \mathrm{m}$ screen opening) from multiple-well monitoring site RHSW (1S/5W-13B1-5), San Bernardino County, California.-Continued

[Abbreviations: ft, feet; $\mu \mathrm{m}$, micrometer]

\begin{tabular}{|c|c|}
\hline Depth (ft) & Description \\
\hline 760 & $\begin{array}{l}\text { Gravelly silty sand (gmS); coarse to very coarse sand, silt, and granules; moderately sorted; subrounded to angular; light } \\
\text { olive brown }(2.5 \mathrm{Y} 5 / 4) \text {. }\end{array}$ \\
\hline 770 & $\begin{array}{l}\text { Gravelly silty sand (gmS); coarse to very coarse sand, silt, and granules; moderately sorted; subrounded to angular; light } \\
\text { olive brown }(2.5 \mathrm{Y} 5 / 4) \text {. }\end{array}$ \\
\hline 780 & $\begin{array}{l}\text { Silty sand (zS); very fine to very coarse sand and silt; very poorly sorted; subangular to angular; light olive brown } \\
(2.5 \mathrm{Y} 5 / 4) \text {. }\end{array}$ \\
\hline 800 & $\begin{array}{l}\text { Sandy clayey silt (sM); silt, clay, and very fine to coarse sand; very poorly sorted; light olive brown (2.5Y 5/3); calcium } \\
\text { carbonate. }\end{array}$ \\
\hline 810 & Sandy clay (sC); clay and coarse sand; poorly sorted; light olive brown (2.5Y 5/4); calcium carbonate. \\
\hline 820 & Sandy clay $(\mathrm{sC})$; clay and coarse to very coarse sand; poorly sorted; light yellowish brown $(2.5 \mathrm{Y} 6 / 3)$; calcium carbonate. \\
\hline 830 & Sandy clay $(\mathrm{sC})$; clay and coarse to very coarse sand; poorly sorted; light yellowish brown $(2.5 \mathrm{Y} 6 / 3)$; calcium carbonate. \\
\hline 840 & Sandy clay $(\mathrm{sC})$; clay and coarse to very coarse sand; poorly sorted; light yellowish brown $(2.5 \mathrm{Y} 6 / 3)$; calcium carbonate. \\
\hline 880 & Sandy clay (sC); clay and very coarse sand; poorly sorted; light olive brown $(2.5 \mathrm{Y} 5 / 3)$ \\
\hline 890 & Sandy clay (sC); clay and very coarse sand; poorly sorted; brown (7.5YR 5/4). \\
\hline 900 & Sandy clay (sC); clay and coarse to very coarse sand; poorly sorted; brown (7.5YR 4/4). \\
\hline 910 & Sandy clay (sC); clay and medium to very coarse sand; poorly sorted; brown (7.5YR 5/4). \\
\hline 920 & Gravelly clay (gM); clay and granules; poorly sorted; yellowish brown (10YR 5/4). \\
\hline 930 & Sandy clay (sC); clay and coarse sand; poorly sorted; yellowish brown (10YR 5/4). \\
\hline 940 & Silty clay (M); clay and silt; well sorted; light olive brown (2.5Y 5/3). \\
\hline 950 & Silty clay (M); clay and silt; well sorted; light olive brown (2.5Y 5/3). \\
\hline 960 & Gravelly clay (gM); clay and granules; poorly sorted; light olive brown $(2.5 \mathrm{Y} 5 / 3)$. \\
\hline 970 & Gravelly silty clay (gM); clay, silt, and granules; poorly sorted; light olive brown (2.5Y $5 / 3)$. \\
\hline 980 & $\begin{array}{l}\text { Silty clayey sand }(\mathrm{mS}) \text {; very fine to very coarse sand, clay, and silt; very poorly sorted; subangular to angular; light olive } \\
\text { brown }(2.5 \mathrm{Y} 5 / 4) \text {. }\end{array}$ \\
\hline
\end{tabular}


Table 12. Lithologic log from sieved drill cuttings (125- $\mu \mathrm{m}$ screen opening) from multiple-well monitoring site FOG1 (1S/4W-29H4-8), San Bernardino County, California.

[Abbreviations: $\mathrm{ft}$, feet; mm, millimeter; $<$, less than; $\mu \mathrm{m}$, micrometer]

\begin{tabular}{|c|c|c|}
\hline \multicolumn{2}{|c|}{ Depth (ft) } & \multirow{2}{*}{ Description } \\
\hline From & To & \\
\hline 0 & 140 & No sample collected. \\
\hline 160 & 180 & Gravelly sand (gS); very fine sand to granules; poorly sorted; angular to subangular; light yellowish brown (2.5Y 6/3). \\
\hline 180 & 200 & $\begin{array}{l}\text { Gravelly sand (gS); medium sand to granules; moderately sorted; angular to subangular; light yellowish brown } \\
(2.5 \mathrm{Y} 6 / 3) \text {. }\end{array}$ \\
\hline 220 & 240 & Gravelly sand (gS); very fine sand to granules; poorly sorted; angular to subangular; light yellowish brown (2.5Y 6/3). \\
\hline 240 & 260 & $\begin{array}{l}\text { Gravelly sand (gS); medium sand to granules with occasional pebbles; moderately sorted; angular to subangular; light } \\
\text { yellowish brown }(2.5 \mathrm{Y} 6 / 3) \text {; pebbles are }<8 \mathrm{~mm} \text { in diameter. }\end{array}$ \\
\hline 260 & 280 & $\begin{array}{l}\text { Gravelly sand (gS); medium sand to pebbles; moderately sorted; angular to subangular; light yellowish brown } \\
(2.5 \mathrm{Y} 6 / 3) \text {; pebbles are }<10 \mathrm{~mm} \text { in diameter. }\end{array}$ \\
\hline 360 & 380 & Silty sand (zS); silt to coarse sand; moderately sorted; subangular; light yellowish brown (2.5Y 6/3). \\
\hline 380 & 400 & Silty sand (zS); silt to coarse sand; moderately sorted; angular to subangular; light yellowish brown (2.5Y 6/3). \\
\hline 400 & 420 & Silty sand (zS); silt to very coarse sand; poorly sorted; subangular; light brownish gray $(2.5 \mathrm{Y} 6 / 2)$ \\
\hline 420 & 440 & Sand (S); very fine to coarse sand; moderately sorted; angular to subangular; light brownish gray (2.5Y 6/2). \\
\hline 440 & 460 & Sandy silt (sZ); silt with medium to very coarse sand; moderately sorted; light olive gray (5Y 6/2). \\
\hline 460 & 480 & Sandy silty clay (sM); clay and silt with medium to very coarse sand; moderately sorted; dark greenish gray $(10 \mathrm{Y} 4 / 1)$. \\
\hline 480 & 500 & No sample collected. \\
\hline 500 & 520 & Sandy silty clay (sM); clay and silt with coarse to very coarse sand; moderately sorted; dark greenish gray (10Y 4/1). \\
\hline 520 & 540 & $\begin{array}{l}\text { Silty clayey sand (mS); fine to medium sand with silt and clay; moderately sorted; subangular; dark greenish gray } \\
(10 \mathrm{Y} 4 / 1) \text {. }\end{array}$ \\
\hline 540 & 560 & Sand (S); very fine to coarse sand; moderately sorted; angular to subangular; olive gray (5Y 5/2). \\
\hline 680 & 700 & Silty sand (zS); silt to very coarse sand; poorly sorted; subangular; light yellowish brown (2.5Y 6/4). \\
\hline 700 & 720 & Silty sand (zS); silt to very coarse sand; poorly sorted; subangular; light yellowish brown (2.5Y 6/4). \\
\hline 720 & 740 & Sand (S); very fine to coarse sand; moderately sorted; angular to subangular; light yellowish brown (2.5Y 6/4). \\
\hline 740 & 760 & Sand (S); very fine to coarse sand; moderately sorted; subangular; light yellowish brown (2.5Y 6/4). \\
\hline 760 & 780 & Silty sand (zS); silt to coarse sand; moderately sorted; subangular; olive gray (5Y 5/2). \\
\hline 780 & 800 & Silty sand (zS); silt to very coarse sand; poorly sorted; angular to subangular; olive gray $(5 \mathrm{Y} 5 / 2)$. \\
\hline 800 & 820 & Silty sand (zS); silt to very coarse sand; poorly sorted; subangular; light olive gray (5Y 6/2). \\
\hline
\end{tabular}


Table 13. Lithologic log from shaker drill cuttings (250- $\mu$ m screen opening) from multiple-well monitoring site FOG1 (1S/4W-29H4-8), San Bernardino County, California.

[Abbreviations: ft, feet; $\mu \mathrm{m}$, micrometer]

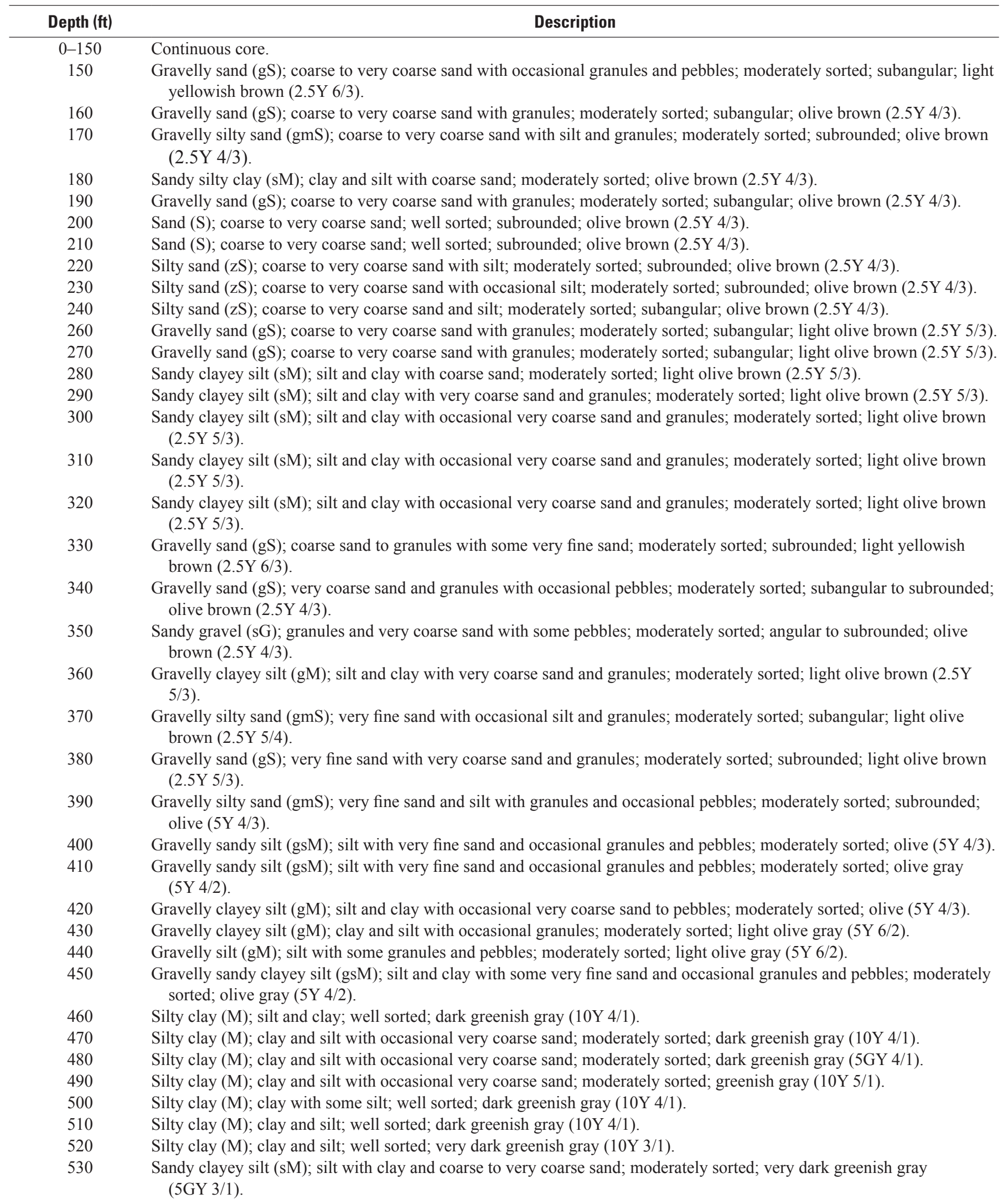


Table 13. Lithologic log from shaker drill cuttings (250- $\mathrm{mm}$ screen opening) from multiple-well monitoring site F0G1 (1S/4W-29H4-8), San Bernardino County, California.-Continued

[Abbreviations: $\mathrm{ft}$, feet; $\mu \mathrm{m}$, micrometer]

\begin{tabular}{|c|c|}
\hline Depth (ft) & Description \\
\hline 540 & $\begin{array}{l}\text { Sandy clayey silt (sM); silt and clay with some coarse to very coarse sand; moderately sorted; dark greenish gray } \\
(5 \mathrm{GY} 4 / 1) \text {. }\end{array}$ \\
\hline 550 & Sandy silt (sZ); silt with very fine and coarse sand; moderately sorted; very dark greenish gray (10Y 3/1). \\
\hline 560 & Sandy clayey silt (sM); silt and clay with some coarse sand; moderately sorted; dark grayish brown (2.5Y $4 / 2)$. \\
\hline 570 & Sandy clayey silt (sM); silt and clay with some coarse to very coarse sand; moderately sorted; olive gray (5Y 4/2). \\
\hline 580 & Sandy clayey silt (sM); silt and clay with some coarse to very coarse sand; moderately sorted; olive gray (5Y 4/2). \\
\hline 590 & Sandy clayey silt (sM); silt with some clay and very coarse sand and granules; moderately sorted; olive gray (5Y 4/2). \\
\hline 600 & Sandy clayey silt (sM); silt with clay and coarse to very coarse sand; moderately sorted; olive gray (5Y $4 / 2)$. \\
\hline 610 & Sandy clayey silt (sM); silt with clay and coarse to very coarse sand; moderately sorted; olive (5Y 4/3). \\
\hline 620 & $\begin{array}{l}\text { Silty sand (zS); coarse to very coarse sand with very fine sand and silt; moderately sorted; subrounded; olive brown } \\
(2.5 \mathrm{Y} 4 / 3) \text {. }\end{array}$ \\
\hline 630 & Sandy silt (sZ); silt and very fine sand with coarse to very coarse sand; moderately sorted; olive gray (5Y 4/2). \\
\hline 640 & $\begin{array}{l}\text { Silty sand (zS); coarse to very coarse sand with silt to very fine sand; moderately sorted; subangular to subrounded; olive } \\
(5 \mathrm{Y} 4 / 3) \text {. }\end{array}$ \\
\hline 650 & Sandy silt (sZ); silt with coarse to very coarse sand; moderately sorted; olive gray (5Y 4/2). \\
\hline 660 & Sandy silt (sZ); silt with coarse to very coarse sand; moderately sorted; olive gray (5Y 4/2). \\
\hline 670 & $\begin{array}{l}\text { Silty sand }(\mathrm{zS}) \text {; coarse to very coarse sand with silt and very fine sand; moderately sorted; subrounded; olive brown } \\
(2.5 \mathrm{Y} 4 / 3) \text {. }\end{array}$ \\
\hline 680 & Sand (S); coarse to very coarse sand with very fine sand; moderately sorted; subrounded; olive brown (2.5Y 4/4). \\
\hline 690 & Sandy silt (sZ); silt and very fine sand with coarse to very coarse sand; moderately sorted; olive (5Y 4/3). \\
\hline 700 & $\begin{array}{l}\text { Silty sand (zS); coarse to very coarse sand with silt and very fine sand; moderately sorted; subrounded; olive gray } \\
(5 \mathrm{Y} 4 / 2) \text {. }\end{array}$ \\
\hline 710 & Sandy silt (sZ); silt with coarse to very coarse sand; moderately sorted; olive gray (5Y 4/2). \\
\hline 720 & Sandy silt (sZ); silt and very fine sand with coarse to very coarse sand; moderately sorted; dark grayish brown (2.5Y 4/2). \\
\hline 730 & Sandy silt (sZ); silt and very fine sand with coarse to very coarse sand; moderately sorted; olive brown (2.5Y 4/3). \\
\hline 740 & Sandy silt (sZ); silt and very fine sand with coarse to very coarse sand; moderately sorted; olive brown (2.5Y 4/3). \\
\hline 750 & Sandy silt (sZ); silt and very fine sand with coarse to very coarse sand; moderately sorted; dark grayish brown (2.5Y $4 / 2)$. \\
\hline 760 & Sandy silt (sZ); silt and very fine sand with coarse to very coarse sand; moderately sorted; olive brown (2.5Y $4 / 3)$. \\
\hline 770 & Sandy silt (sZ); silt and very fine sand with coarse to very coarse sand; moderately sorted; greenish gray (10Y 5/1). \\
\hline 780 & $\begin{array}{l}\text { Sandy silt (sZ); silt and very fine sand with occasional coarse to very coarse sand; moderately sorted; dark greenish gray } \\
(10 \mathrm{Y} 4 / 1) \text {. }\end{array}$ \\
\hline 790 & Sandy silt (sZ); silt and very fine sand with coarse to very coarse sand; moderately sorted; dark greenish gray (5GY 4/1). \\
\hline 800 & Sandy silt (sZ); silt and very fine sand with coarse to very coarse sand; moderately sorted; olive (5Y 4/3). \\
\hline 810 & Sandy silt (sZ); silt and very fine sand with coarse to very coarse sand; moderately sorted; olive gray (5Y 4/2). \\
\hline 820 & Sandy silt (sZ); silt and very fine sand with coarse to very coarse sand; moderately sorted; olive gray (5Y 4/2). \\
\hline
\end{tabular}


Table 14. Lithologic log from sieved drill cuttings (125- $\mu \mathrm{m}$ screen opening) from multiple-well monitoring site F0G2 (1S/4W-29K1-5), San Bernardino County, California.

[Abbreviations: $\mathrm{ft}$, feet; $\mathrm{mm}$, millimeter; $<$, less than; $\mu \mathrm{m}$, micrometer]

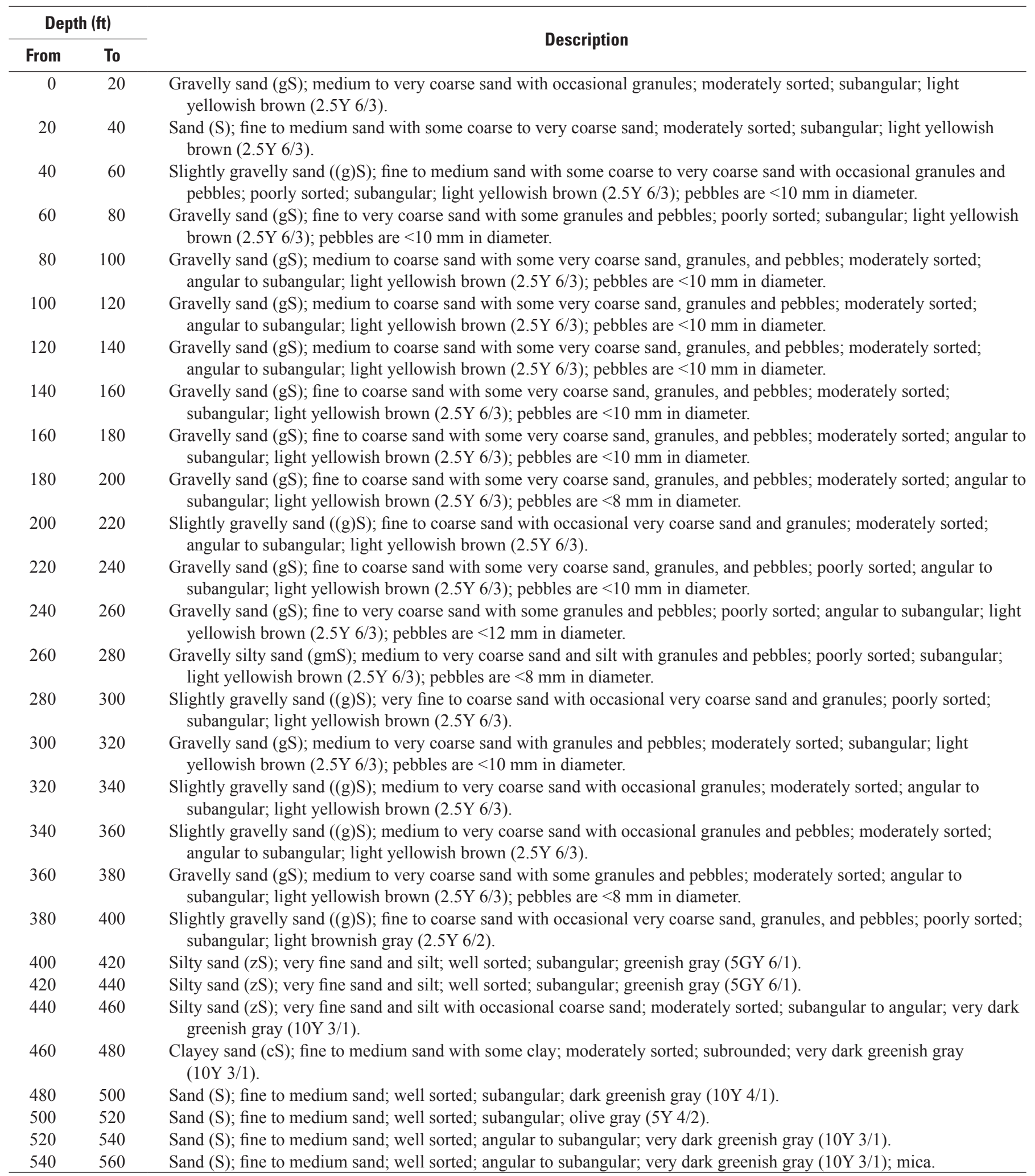


Table 15. Lithologic log from shaker drill cuttings (250- $\mu$ m screen opening) from multiple-well monitoring site F0G2 (1S/4W-29K1-5), San Bernardino County, California.

[Abbreviations: $\mathrm{ft}$, feet; mm, millimeter; >, greater than; $\mu \mathrm{m}$, micrometer]

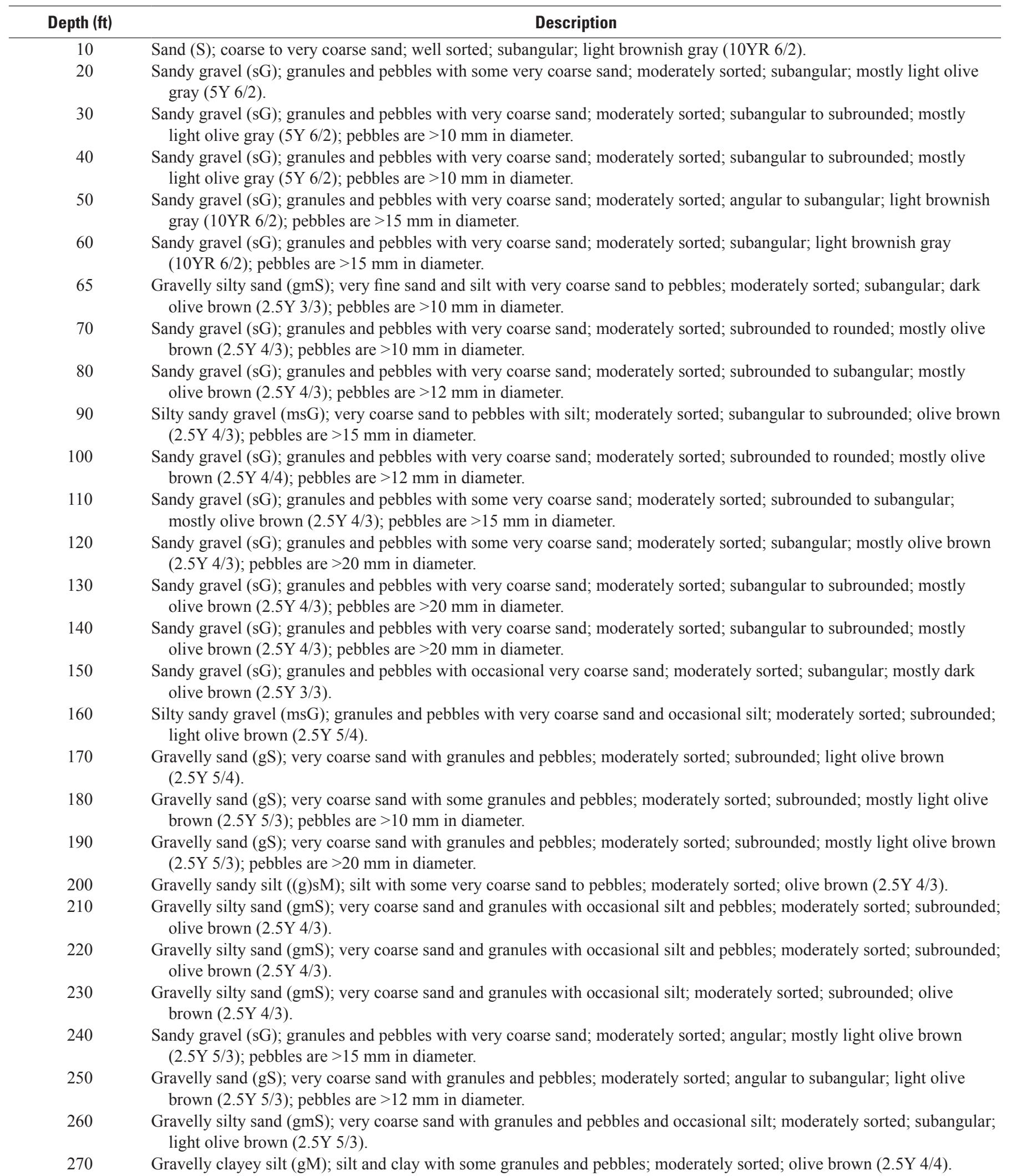


Table 15. Lithologic log from shaker drill cuttings (250- $\mu \mathrm{m}$ screen opening) from multiple-well monitoring site F0G2 (1S/4W-29K1-5), San Bernardino County, California.-Continued

[Abbreviations: $\mathrm{ft}$, feet; $\mathrm{mm}$, millimeter; >, greater than; $\mu \mathrm{m}$, micrometer]

\begin{tabular}{|c|c|}
\hline Depth (ft) & Description \\
\hline 280 & $\begin{array}{l}\text { Sand (S); very fine sand with occasional granules and pebbles; moderately sorted; subrounded; light olive brown } \\
\text { (2.5Y 5/4). }\end{array}$ \\
\hline 290 & Sand (S); very fine sand with occasional granules; well sorted; subrounded; light olive brown (2.5Y 5/4). \\
\hline 300 & $\begin{array}{l}\text { Slightly gravelly silty sand }((\mathrm{g}) \mathrm{mS}) \text {; very coarse sand with occasional pebbles and silt; moderately sorted; subrounded; } \\
\text { light olive brown }(2.5 \mathrm{Y} 5 / 4) \text {. }\end{array}$ \\
\hline 310 & $\begin{array}{l}\text { Slightly gravelly silty sand }((\mathrm{g}) \mathrm{mS}) \text {; very coarse sand with occasional silt and pebbles and granules; moderately sorted; } \\
\text { subrounded; light olive brown }(2.5 \mathrm{Y} 5 / 4) \text {. }\end{array}$ \\
\hline 320 & $\begin{array}{l}\text { Gravelly silty sand (gmS); very coarse sand with some granules and pebbles and silt; moderately sorted; subrounded; light } \\
\text { olive brown }(2.5 \mathrm{Y} 5 / 4) \text {. }\end{array}$ \\
\hline 330 & $\begin{array}{l}\text { Gravelly silty sand (gmS); very coarse sand to pebbles with occasional silt; moderately sorted; subangular to subrounded; } \\
\text { light olive brown }(2.5 \mathrm{Y} 5 / 4) \text {; pebbles are }>10 \mathrm{~mm} \text { in diameter. }\end{array}$ \\
\hline 340 & $\begin{array}{l}\text { Sandy gravel (sG); granules to pebbles with very coarse to coarse sand; moderately sorted; subangular; light olive brown } \\
\quad(2.5 \mathrm{Y} 5 / 4) \text {; pebbles are }>17 \mathrm{~mm} \text { in diameter. }\end{array}$ \\
\hline 350 & $\begin{array}{l}\text { Slightly gravelly sand }((\mathrm{g}) \mathrm{S}) \text {; very coarse sand with occasional granules; well sorted; subangular to subrounded; light } \\
\text { olive brown }(2.5 \mathrm{Y} 5 / 4) \text {. }\end{array}$ \\
\hline 360 & Sandy silty clay (sM); clay and silt with some very coarse sand; moderately sorted; olive (5Y 5/3). \\
\hline 370 & $\begin{array}{l}\text { Slightly gravelly silty sand }((\mathrm{g}) \mathrm{mS}) \text {; very coarse sand with silt and very fine sand with occasional granules; moderately } \\
\text { sorted; subrounded; olive ( } 5 \mathrm{Y} 5 / 3) \text {. }\end{array}$ \\
\hline 380 & $\begin{array}{l}\text { Slightly gravelly sand }((\mathrm{g}) \mathrm{S}) \text {; very coarse sand with occasional granules and very little silt; moderately sorted; subangular; } \\
\text { olive (5Y 5/3). }\end{array}$ \\
\hline 390 & $\begin{array}{l}\text { Sandy clayey silt (sM); silt with some clay and occasional very coarse sand; moderately sorted; dark greenish gray } \\
(10 \mathrm{Y} 4 / 1) \text {. }\end{array}$ \\
\hline 400 & Clayey silt (M); silt with some clay; well sorted; dark greenish gray (10Y 4/1). \\
\hline 410 & Clayey silt (M); silt with some clay; well sorted; dark greenish gray (10Y 4/1). \\
\hline 420 & Clayey silt (M); silt and clay; well sorted; dark greenish gray (10Y 4/1). \\
\hline 430 & Silty clay (M); clay and silt; well sorted; dark greenish gray (10Y 4/1). \\
\hline 440 & Clayey silt (M); silt and clay; well sorted; dark greenish gray (10Y 4/1). \\
\hline 450 & $\begin{array}{l}\text { Slightly gravelly clayey silt }((\mathrm{g}) \mathrm{M}) \text {; silt and clay with occasional very coarse sand to pebbles; moderately sorted; very } \\
\text { dark greenish gray }(10 \mathrm{Y} 3 / 1) \text {; pebbles are }>10 \mathrm{~mm} \text { in diameter. }\end{array}$ \\
\hline 460 & $\begin{array}{l}\text { Slightly gravelly sandy silt ((g)sM); silt with some coarse sand to granules; moderately sorted; very dark greenish gray } \\
\text { (10Y 3/1); dark organic pieces. }\end{array}$ \\
\hline 470 & $\begin{array}{l}\text { Sandy silt (sZ); silt and very fine sand with occasional very coarse sand; moderately sorted; very dark greenish gray } \\
\text { (10Y 3/1). }\end{array}$ \\
\hline 480 & Sand $(\mathrm{S})$; very fine sand with coarse to very coarse sand; moderately sorted; subangular; olive gray (5Y 5/2). \\
\hline 490 & Sand (S); coarse to very coarse sand with some medium sand; moderately sorted; subangular; dark gray (5Y 4/1). \\
\hline 500 & Silty sand (zS); coarse to very coarse sand with occasional silt; moderately sorted; subangular; dark gray (5Y 4/1). \\
\hline 510 & Silty sand (zS); coarse to very coarse sand with occasional silt; moderately sorted; subangular; light olive gray (5Y 6/2). \\
\hline 520 & Sandy silt (sZ); silt with coarse to very coarse sand; moderately sorted; light olive gray (5Y 6/2). \\
\hline 530 & $\begin{array}{l}\text { Silty sand (zS); coarse to very coarse sand with silt and very fine sand; moderately sorted; angular to subangular; light } \\
\text { olive gray }(5 \mathrm{Y} 6 / 2) \text {. }\end{array}$ \\
\hline 540 & $\begin{array}{l}\text { Sand }(\mathrm{S}) \text {; coarse to very coarse sand with very fine sand; moderately sorted; angular to subangular; light olive gray } \\
(5 \mathrm{Y} 6 / 2) \text {. }\end{array}$ \\
\hline 550 & Sand $(\mathrm{S})$; coarse to very coarse sand; well sorted; angular to subangular; olive gray $(5 \mathrm{Y} 4 / 2)$; biotite rich. \\
\hline 560 & Sand $(\mathrm{S})$; coarse to very coarse sand; well sorted; angular to subangular; olive gray (5Y 5/2); biotite rich. \\
\hline
\end{tabular}


Table 16. Date range of available water-level data, count of water-level measurements, and maximum and minimum water-level elevations for select wells, San Bernardino County, California.

[State well number: See well-numbering diagram in text. Location of sites shown in figure 2. Abbreviations: ft, feet; mm/dd/yyyy, month/day/year; NAVD 88, North American Vertical Datum of 1988; USGS, U.S. Geological Survey]

\begin{tabular}{|c|c|c|c|c|c|c|c|}
\hline $\begin{array}{c}\text { USGS site } \\
\text { identification } \\
\text { number }\end{array}$ & $\begin{array}{l}\text { State well } \\
\text { number }\end{array}$ & $\begin{array}{l}\text { Common } \\
\text { name }\end{array}$ & $\begin{array}{c}\text { Start date } \\
\text { (mm/dd/yyyy) }\end{array}$ & $\begin{array}{c}\text { End date } \\
(\mathrm{mm} / \mathrm{dd} / \mathrm{yyyy})\end{array}$ & $\begin{array}{c}\text { Number of } \\
\text { measurements }\end{array}$ & $\begin{array}{c}\text { Maximum } \\
\text { water level } \\
\text { (ft above NAVD 88) }\end{array}$ & $\begin{array}{c}\text { Minimum } \\
\text { water level } \\
\text { (ft above NAVD 88) }\end{array}$ \\
\hline 341013117253901 & 1N/5W-17L1 & RCZ6-1 & $06 / 27 / 2011$ & $05 / 22 / 2013$ & 19 & $1,094.25$ & $1,083.92$ \\
\hline 341013117253902 & $1 \mathrm{~N} / 5 \mathrm{~W}-17 \mathrm{~L} 2$ & RCZ6-2 & $06 / 27 / 2011$ & $05 / 22 / 2013$ & 19 & $1,093.77$ & $1,083.00$ \\
\hline 341013117253903 & $1 \mathrm{~N} / 5 \mathrm{~W}-17 \mathrm{~L} 3$ & RCZ6-3 & $06 / 27 / 2011$ & $05 / 22 / 2013$ & 21 & $1,659.87$ & $1,608.23$ \\
\hline 341013117253904 & $1 \mathrm{~N} / 5 \mathrm{~W}-17 \mathrm{~L} 4$ & RCZ6-4 & $06 / 27 / 2011$ & $05 / 22 / 2013$ & 21 & $1,681.82$ & $1,608.57$ \\
\hline 340851117281901 & $1 \mathrm{~N} / 6 \mathrm{~W}-26 \mathrm{~A} 1$ & RCNE-1 & $08 / 26 / 2002$ & $05 / 30 / 2013$ & 102 & $1,035.36$ & 774.38 \\
\hline 340851117281902 & $1 \mathrm{~N} / 6 \mathrm{~W}-26 \mathrm{~A} 2$ & RCNE-2 & $06 / 20 / 2002$ & $05 / 30 / 2013$ & 104 & $1,084.98$ & $1,051.24$ \\
\hline 340851117281903 & $1 \mathrm{~N} / 6 \mathrm{~W}-26 \mathrm{~A} 3$ & RCNE-3 & $06 / 20 / 2002$ & $05 / 30 / 2013$ & 103 & $1,085.98$ & $1,051.72$ \\
\hline 340829117284301 & $1 \mathrm{~N} / 6 \mathrm{~W}-26 \mathrm{~K} 2$ & RCSW-1 & $07 / 16 / 2002$ & $05 / 30 / 2013$ & 83 & $1,066.14$ & 873.10 \\
\hline 340829117284302 & $1 \mathrm{~N} / 6 \mathrm{~W}-26 \mathrm{~K} 3$ & RCSW-2 & $06 / 20 / 2002$ & $05 / 30 / 2013$ & 83 & $1,100.31$ & $1,065.88$ \\
\hline 340716117230601 & $1 \mathrm{~S} / 5 \mathrm{~W}-03 \mathrm{~A} 3$ & CRCR-1 & $07 / 03 / 2008$ & $05 / 21 / 2013$ & 44 & 992.17 & 966.64 \\
\hline 340716117230605 & $1 \mathrm{~S} / 5 \mathrm{~W}-03 \mathrm{~A} 7$ & CRCR-5 & $07 / 03 / 2008$ & $05 / 21 / 2013$ & 44 & 992.77 & 969.61 \\
\hline 340716117230606 & $1 \mathrm{~S} / 5 \mathrm{~W}-03 \mathrm{~A} 8$ & CRCR-6 & $01 / 22 / 2006$ & $05 / 21 / 2013$ & 38 & $1,290.72$ & $1,246.70$ \\
\hline 340521117212001 & $1 \mathrm{~S} / 5 \mathrm{~W}-13 \mathrm{~B} 1$ & RHSW-1 & 09/04/2008 & $05 / 21 / 2013$ & 45 & 917.94 & 904.20 \\
\hline 340521117212002 & 1S/5W-13B2 & RHSW-2 & 09/04/2008 & $05 / 21 / 2013$ & 47 & 915.98 & 894.51 \\
\hline 340521117212003 & $1 \mathrm{~S} / 5 \mathrm{~W}-13 \mathrm{~B} 3$ & RHSW-3 & 09/04/2008 & $05 / 21 / 2013$ & 46 & 901.26 & 881.15 \\
\hline 340521117212004 & 1S/5W-13B4 & RHSW-4 & 09/04/2008 & $05 / 21 / 2013$ & 46 & 902.02 & 788.76 \\
\hline 340521117212005 & 1S/5W-13B5 & RHSW-5 & 09/04/2008 & $05 / 21 / 2013$ & 46 & 910.78 & 892.20 \\
\hline 340326117185301 & 1S/4W-29H4 & FOG1-1 & $06 / 28 / 2002$ & $06 / 03 / 2013$ & 116 & 868.94 & 848.16 \\
\hline 340326117185302 & 1S/4W-29H5 & FOG1-2 & $09 / 25 / 2002$ & $06 / 03 / 2013$ & 115 & 868.39 & 849.47 \\
\hline 340326117185303 & 1S/4W-29H6 & FOG1-3 & $06 / 28 / 2002$ & $06 / 03 / 2013$ & 116 & 895.42 & 838.29 \\
\hline 340326117185304 & 1S/4W-29H7 & FOG1-4 & $06 / 29 / 2002$ & $06 / 03 / 2013$ & 116 & 910.87 & 826.07 \\
\hline
\end{tabular}



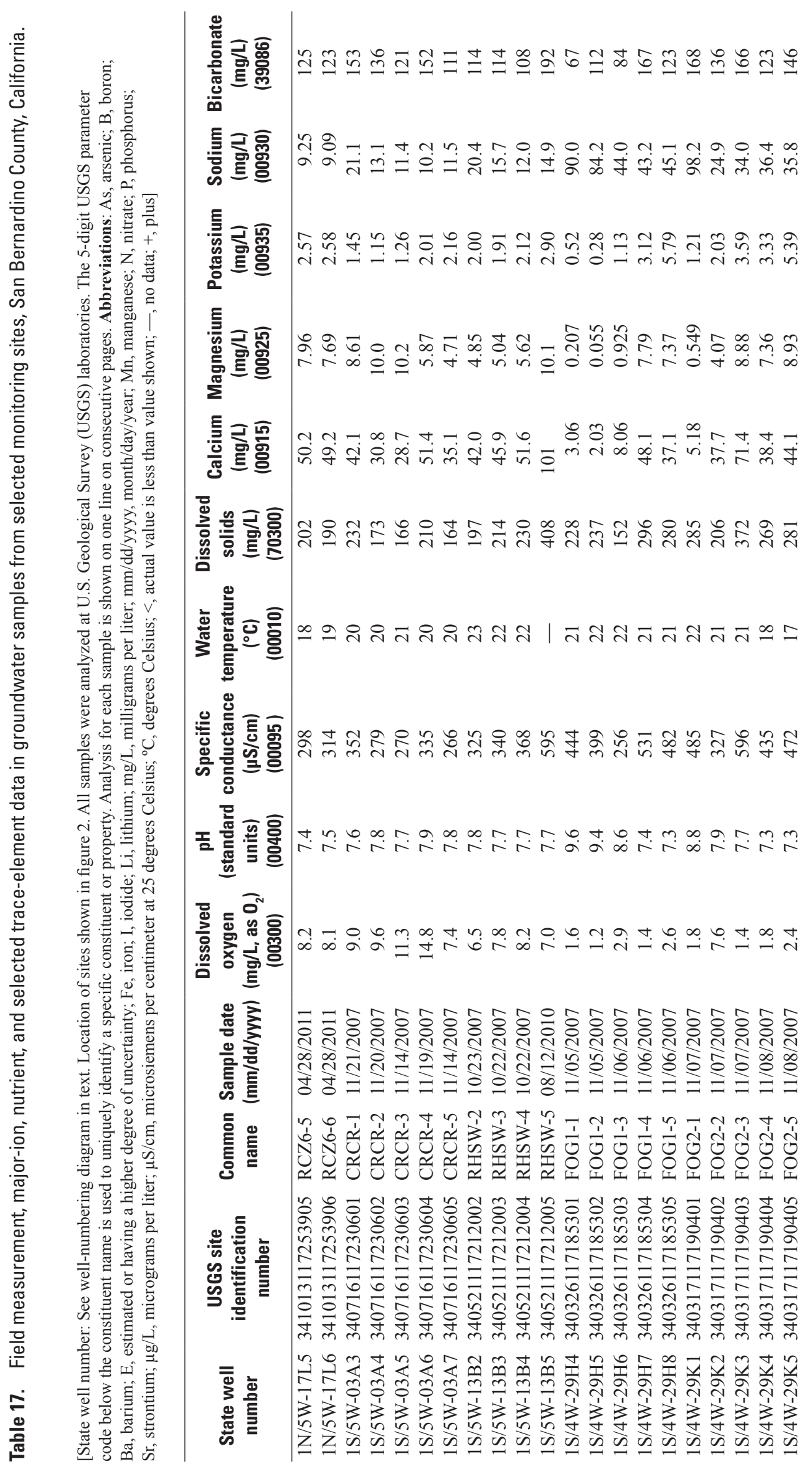


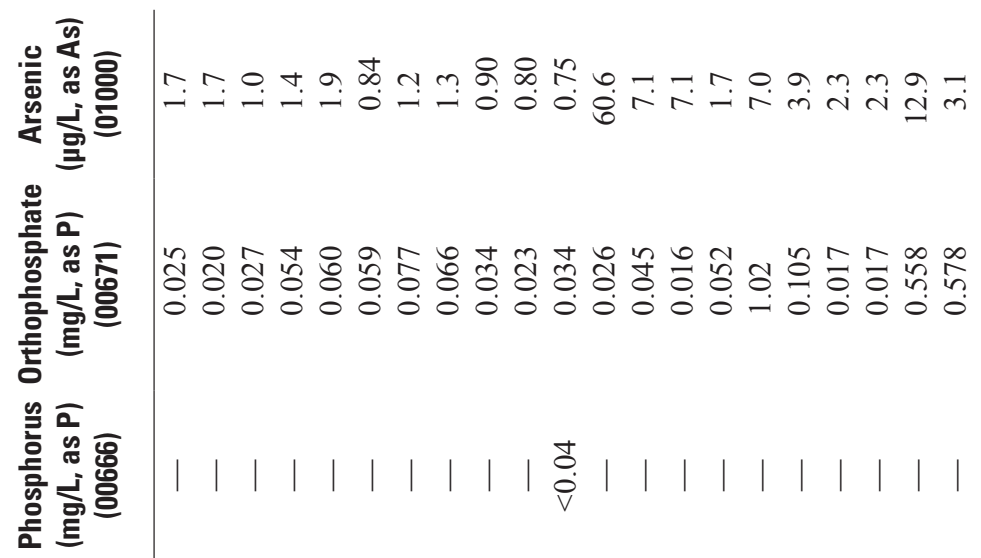

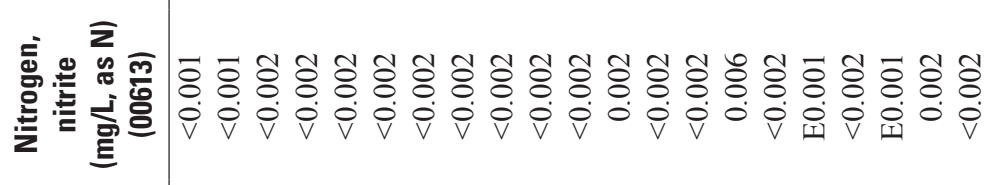

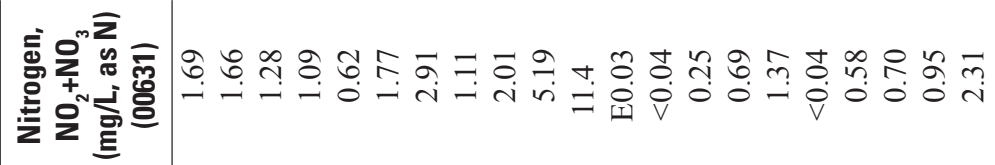

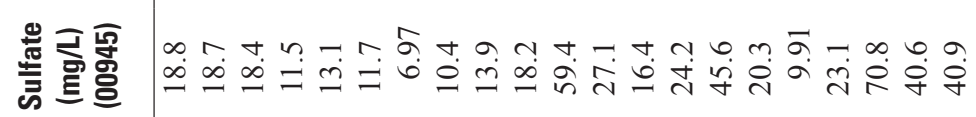
造

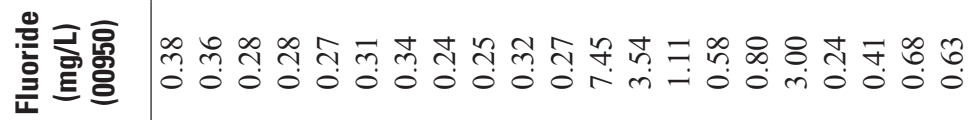

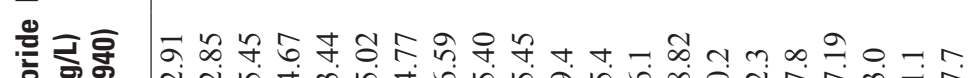

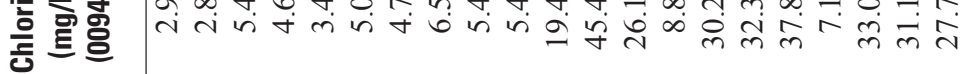

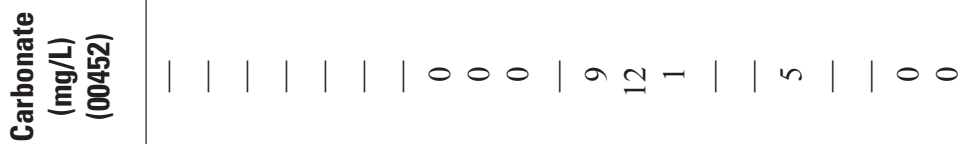

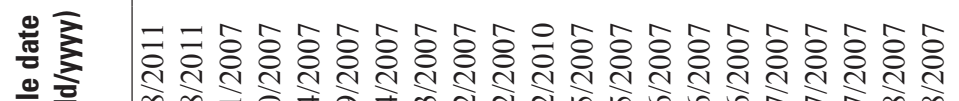
믈

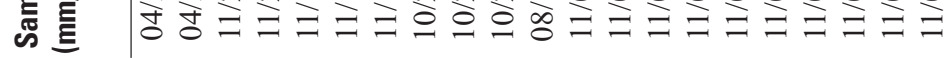
言 㝘

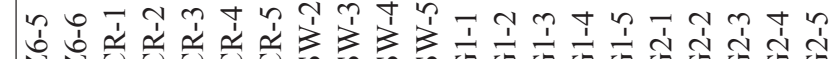

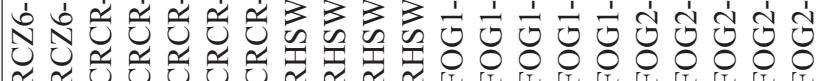

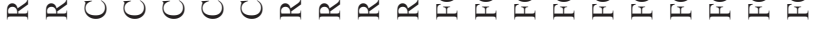

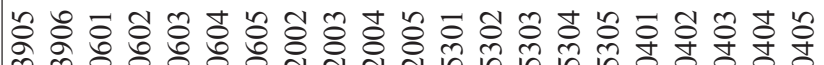

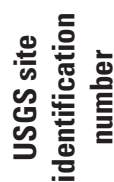
กี

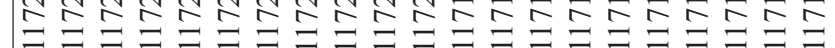

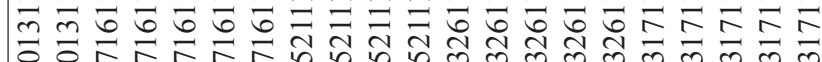

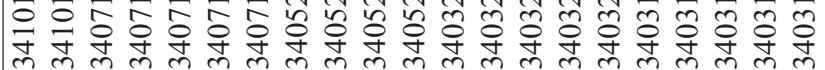

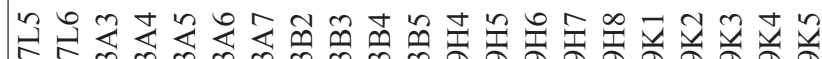
든

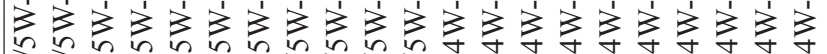

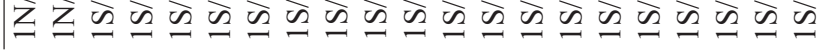




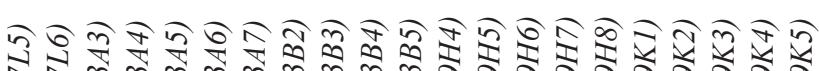

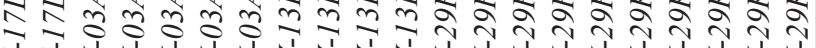

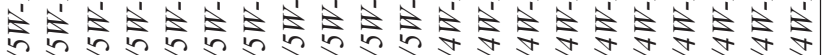

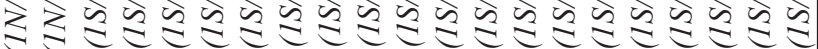

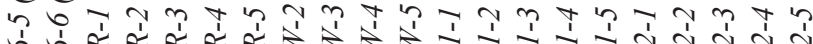

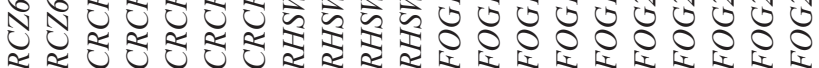
कis

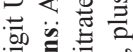

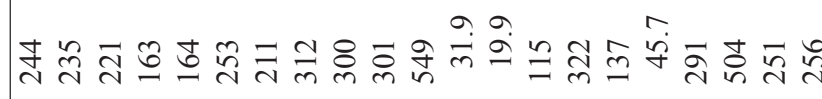

这

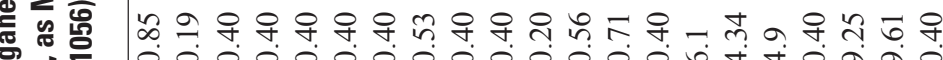

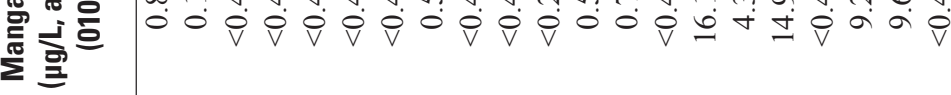
高总兽 更 흔 $\stackrel{\mathscr{E}}{\mathrm{I}}$ 홀

흘

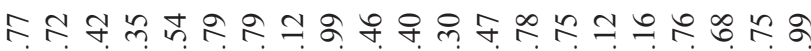

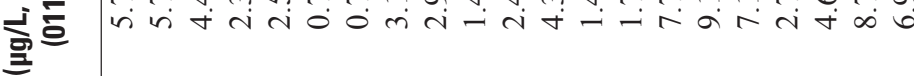

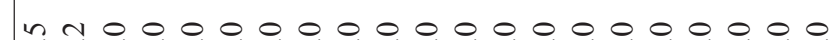

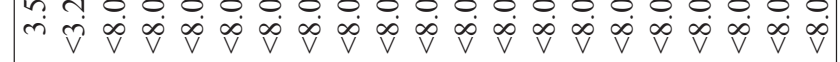
再

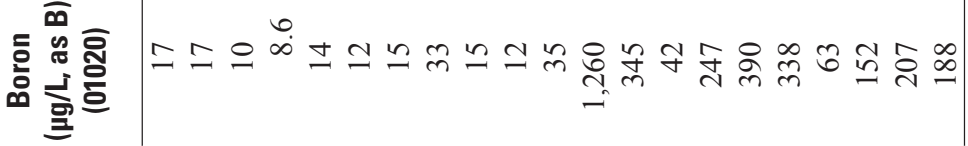

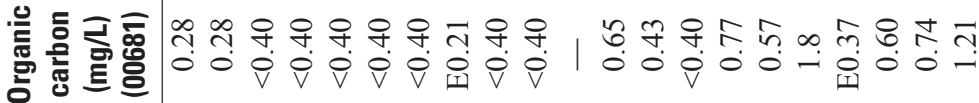

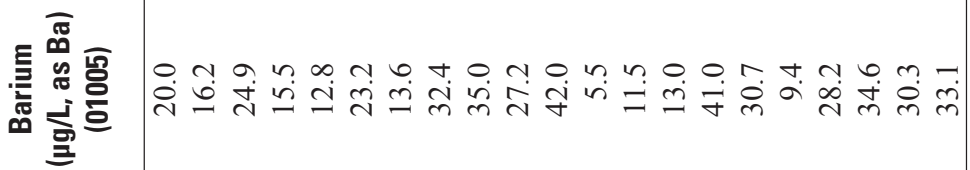

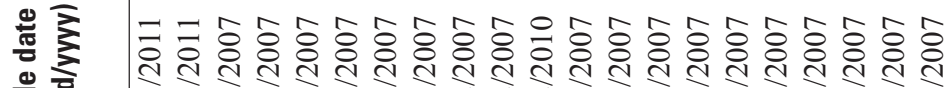

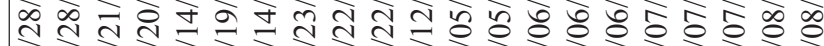
于ᄒㅇㅎㅇ

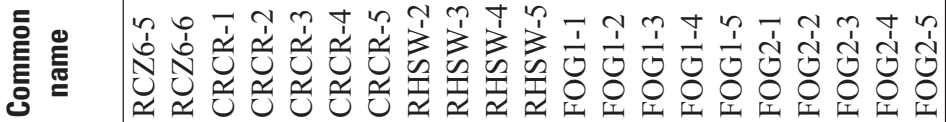

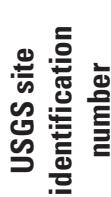

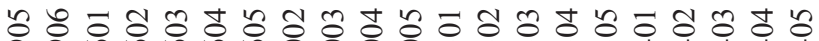

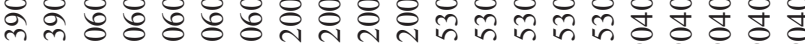

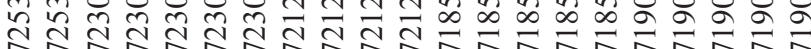

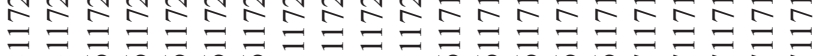

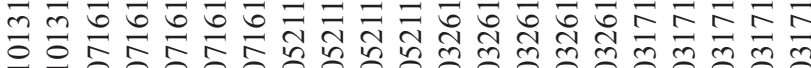

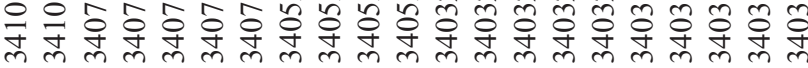
言 
Table 18. Deuterium, oxygen-18, and tritium data in groundwater samples from selected monitoring sites, San Bernardino County, California.

[State well-number: See well numbering diagram in text. Location of sites shown in figure 2. All data were analyzed at U.S. Geological Survey (USGS) laboratories. The 5-digit USGS parameter code below the constituent name is used to uniquely identify a specific constituent or property. Abbreviations: mm/dd/yyyy, month/day/year; per mil, isotopic ratio in parts per thousand; pmc, percent modern carbon; - , no data]

\begin{tabular}{|c|c|c|c|c|c|c|c|c|}
\hline $\begin{array}{c}\text { State well } \\
\text { number }\end{array}$ & $\begin{array}{c}\text { USGS site } \\
\text { identification } \\
\text { number }\end{array}$ & $\begin{array}{c}\text { Common } \\
\text { name }\end{array}$ & $\begin{array}{l}\text { Sample date } \\
\text { (mm/dd/yyyy) }\end{array}$ & $\begin{array}{c}\delta^{18} 0 \\
\text { delta } \\
\text { oxygen-18 } \\
\text { (per mil) } \\
(82085)\end{array}$ & $\begin{array}{c}\delta D, \\
\text { deuterium/ } \\
\text { protium ratio } \\
\text { (per mil) } \\
\text { (82082) }\end{array}$ & $\begin{array}{c}\text { Tritium } \\
\text { (picocuries } \\
\text { per liter) } \\
(07000)\end{array}$ & $\begin{array}{c}\text { Delta } \\
\text { carbon-13 } \\
\text { (per mil) } \\
(\mathbf{8 2 0 8 1 )}\end{array}$ & $\begin{array}{c}\text { Carbon-14 } \\
\text { (pmc) } \\
(49933)\end{array}$ \\
\hline 1N/5W-17L5 & 341013117253905 & RCZ6-5 & $04 / 28 / 2011$ & -9.26 & -61.90 & 11 & -13.24 & 91.82 \\
\hline 1N/5W-17L6 & 341013117253906 & RCZ6-6 & $04 / 28 / 2011$ & -9.31 & -61.70 & 11 & -13.30 & 92.05 \\
\hline $1 \mathrm{~S} / 5 \mathrm{~W}-03 \mathrm{~A} 5$ & 340716117230603 & CRCR-3 & $11 / 30 / 2005$ & -8.27 & -51.20 & - & -13.50 & 77.85 \\
\hline $1 \mathrm{~S} / 5 \mathrm{~W}-03 \mathrm{~A} 6$ & 340716117230604 & CRCR-4 & $11 / 30 / 2005$ & -8.88 & -57.70 & 2.0 & -12.40 & 81.31 \\
\hline $1 \mathrm{~S} / 5 \mathrm{~W}-03 \mathrm{~A} 7$ & 340716117230605 & CRCR-5 & $11 / 29 / 2005$ & -8.16 & -51.90 & 11 & -13.70 & 73.94 \\
\hline $1 \mathrm{~S} / 5 \mathrm{~W}-13 \mathrm{~B} 2$ & 340521117212002 & RHSW-2 & $02 / 28 / 2006$ & -8.49 & -56.60 & 0.2 & -11.70 & 64.63 \\
\hline $1 \mathrm{~S} / 5 \mathrm{~W}-13 \mathrm{~B} 3$ & 340521117212003 & RHSW-3 & $02 / 27 / 2006$ & -8.62 & -57.50 & 0.3 & -12.70 & 76.36 \\
\hline 1S/4W-29H6 & 340326117185303 & FOG1-3 & $06 / 28 / 2002$ & -8.90 & -58.70 & - & -12.36 & 21.37 \\
\hline $1 \mathrm{~S} / 4 \mathrm{~W}-29 \mathrm{H} 7$ & 340326117185304 & FOG1-4 & $06 / 29 / 2002$ & -8.21 & -56.20 & 11 & -12.63 & 98.51 \\
\hline $1 \mathrm{~S} / 4 \mathrm{~W}-29 \mathrm{H} 8$ & 340326117185305 & FOG1-5 & $02 / 09 / 2006$ & -8.53 & -60.80 & 13 & -11.60 & 95.70 \\
\hline $1 \mathrm{~S} / 4 \mathrm{~W}-29 \mathrm{~K} 1$ & 340317117190401 & FOG2-1 & $06 / 26 / 2002$ & -9.31 & -63.90 & - & -9.29 & 4.030 \\
\hline $1 \mathrm{~S} / 4 \mathrm{~W}-29 \mathrm{~K} 2$ & 340317117190402 & FOG2-2 & $06 / 26 / 2002$ & -8.92 & -59.50 & 3.4 & -12.75 & 91.68 \\
\hline $1 \mathrm{~S} / 4 \mathrm{~W}-29 \mathrm{~K} 3$ & 340317117190403 & FOG2-3 & $06 / 27 / 2002$ & -8.54 & -58.50 & 8.5 & -13.35 & 104.4 \\
\hline $1 \mathrm{~S} / 4 \mathrm{~W}-29 \mathrm{~K} 4$ & 340317117190404 & FOG2-4 & $06 / 25 / 2002$ & -7.91 & -56.30 & 11 & -13.09 & 87.87 \\
\hline $1 \mathrm{~S} / 4 \mathrm{~W}-29 \mathrm{~K} 5$ & 340317117190405 & FOG2-5 & $06 / 25 / 2002$ & -7.37 & -53.00 & 17 & -14.41 & 91.36 \\
\hline
\end{tabular}


Prepared by the Sacramento Publishing Service Center.

For more information concerning this report, contact:

Director

U.S. Geological Survey

California Water Science Center

6000 J Street, Placer Hall

Sacramento, CA 95819

dc_ca@usgs.gov

or visit our Web site at:

http://ca.water.usgs.gov 


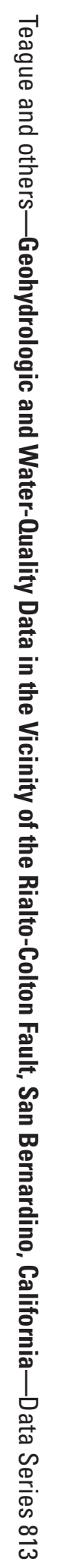

